\title{
\#USGS
}

\section{Mineralogy and Morphology of Amphiboles Observed in Soils and Rocks in El Dorado Hills, California}

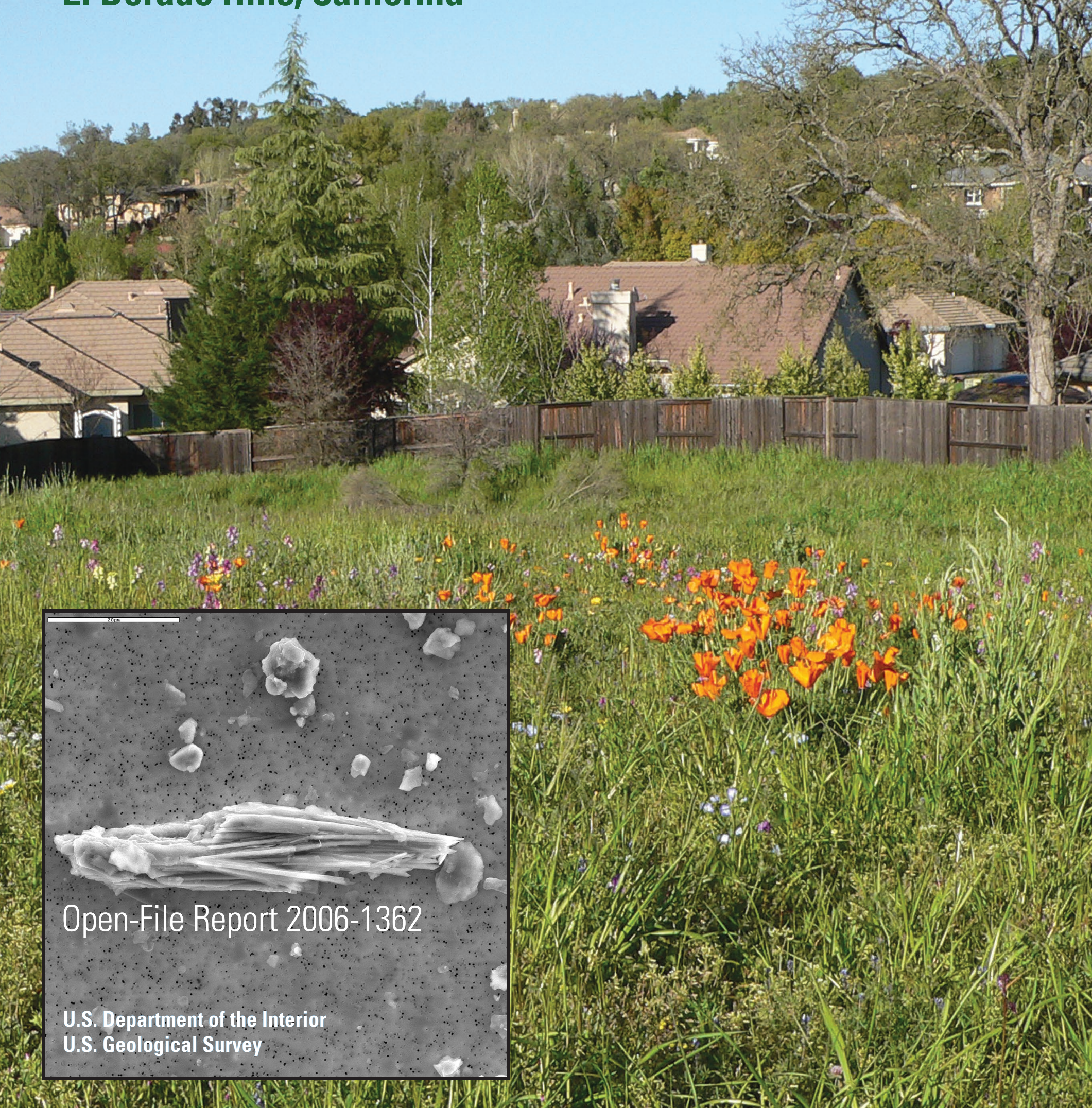




\section{Mineralogy and Morphology of Amphiboles Observed in Soils and Rocks in El Dorado Hills, California}

By G.P. Meeker, H.A. Lowers, G.A. Swayze, B.S. Van Gosen, S.J. Sutley, and I.K. Brownfield

Prepared for U.S. Environmental Protection Agency Region 9 IAG DW1492190501-2

Open-File Report 2006-1362 


\section{U.S. Department of the Interior DIRK KEMPTHORNE, Secretary}

\section{U.S. Geological Survey \\ Mark D. Myers, Director}

\section{U.S. Geological Survey, Reston, Virginia: 2006}

For product and ordering information:

World Wide Web: http://www.usgs.gov/pubprod

Telephone: 1-888-ASK-USGS

For more information on the USGS--the Federal source for science about the Earth, its natural and living resources, natural hazards, and the environment:

World Wide Web: http://www.usgs.gov

Telephone: 1-888-ASK-USGS

Any use of trade, product, or firm names is for descriptive purposes only and does not imply endorsement by the U.S. Government.

Although this report is in the public domain, permission must be secured from the individual copyright owners to reproduce any copyrighted materials contained within this report.

\section{Suggested citation:}

Meeker, G.P., Lowers, H.A., Swayze, G.A., Van Gosen, B.S., Sutley, S.J., and Brownfield, I.K., 2006, Mineralogy and morphology of amphiboles observed in soils and rocks in El Dorado Hills, California: December 2006,

U.S. Geological Survey Open-File Report 2006-1362, 47 p. 


\section{Contents}

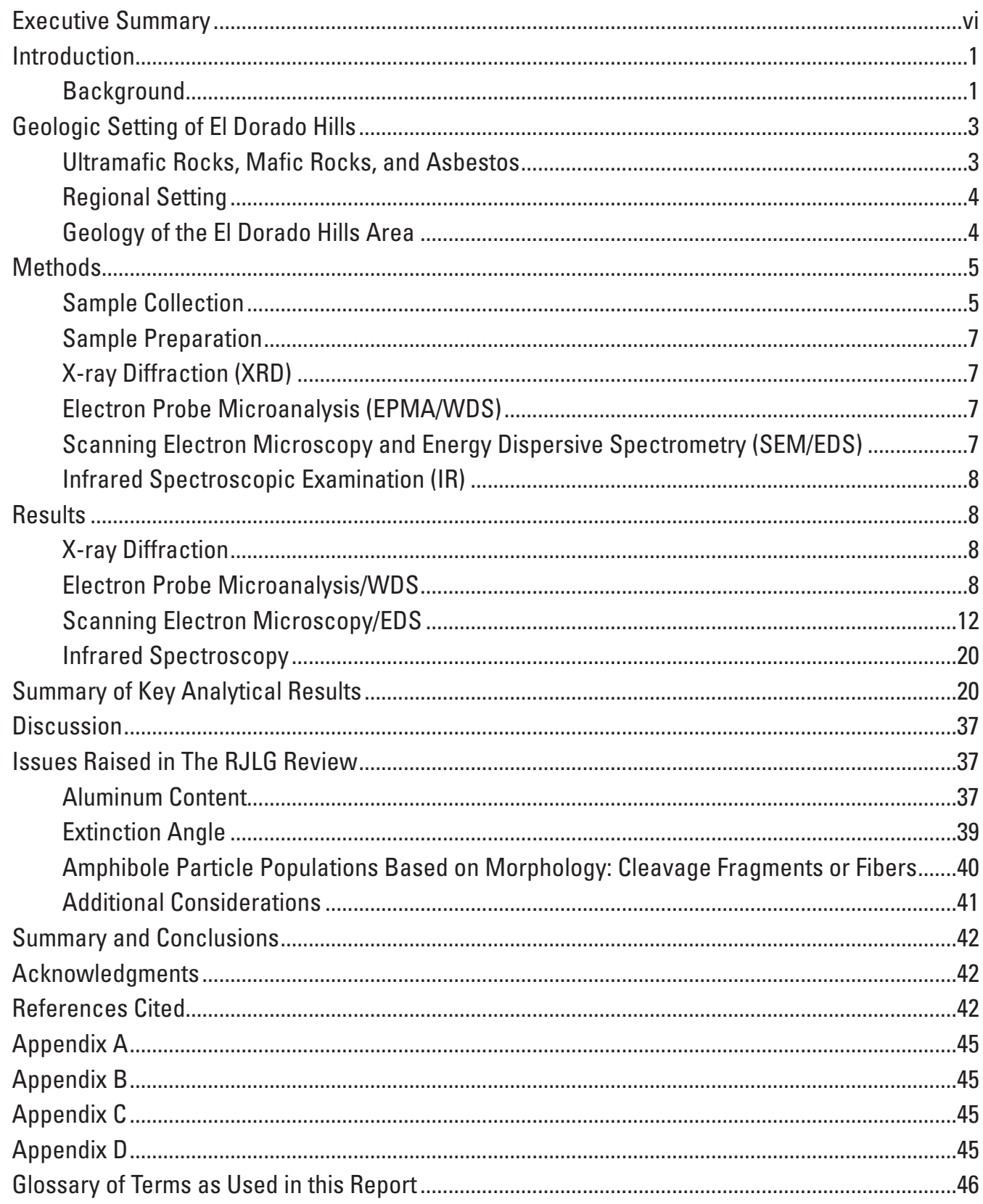

\section{Figures}

1. Generalized geologic map of the El Dorado Hills community, adapted from Churchill and others (2000)

2. Soil collection procedure 
3. Composition of feldspars plotted on orthoclase (Or), albite (Ab), and anorthite (An) ternary.

4. Composition of chlorite plotted on aluminum (Al), iron (Fe), and magnesium (Mg) ternary.

5. Epidote compositions plotted on aluminum (Al) and iron ( $\mathrm{Fe})$ binary diagram. All analyses fall in the clinozoisite compositional field

6. Composition and nomenclature as defined by Leake and others (1997) of El Dorado Hills amphiboles analyzed on polished thin sections of rock samples by EPMA/WDS [Mg\# = Mg/(Mg+Fe $\left.{ }^{2+}\right)$; Si, silicon].

7. Diagram showing an example of how the classification of the amphibole can change with the method used to determine ferrous/ferric iron ratios.

8. Serpentine (probably chrysotile) structures found in sample ED06-09A and sample GSNYT06-07A1 on the New York Creek Trail.

9. SEM-EDS analyses of amphiboles from soil samples collected from various locations in the study area in El Dorado Hills, California, and on the New York Creek Trail

10. Size distribution of amphibole particles analyzed from soil samples.

11. Size distribution of amphibole particles less than or equal to 3 micrometers $(\mu \mathrm{m})$ width

12. Size distribution of tremolitic particles from soil sample ED06-07A compared to all amphibole particles from all soil samples

13. Fibrous tremolite with other particles collected from soil next to the El Dorado Hills recreation center (ED06-07A)

14. Fibrous to asbestiform tremolite at four different magnifications.....................................27

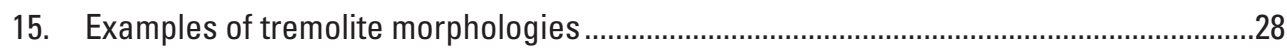

16. Comparison of amphibole size data from soils collected by the

U.S. Geological Survey and air filters collected by the U.S. Environmental Protection Agency......

17. Comparison of amphibole aspect ratios from soils collected by the

U.S. Geological Survey and air filters collected by the

U.S. Environmental Protection Agency.

18. SEM-EDS cation proportions of amphibole particles from air filters collected by the U.S. Environmental Protection Agency.

19. Actinolite (a) and tremolite (c) in rock samples have similar morphology to actinolite (b) and tremolite (d) found in soils. $\mu \mathrm{m}$, micrometer.

20. Typical weathering features of (a) magnesiohornblende and actinolite (b, c, and d). $\mu \mathrm{m}$, micrometer.

21. Comparison of EPMA/WDS analyses of amphibole in rock samples to SEM/EDS analyses of amphiboles in soils.

22. Electrical box sample location from the south wall of the Recreation Center and SEM images of typical amphiboles collected from top surface of the electrical box

23. Aluminum (Al) content of amphibole particles less than $(<) 3$ micrometers $(\mu \mathrm{m})$ in width analyzed in this study as a function of aspect ratio.

24. Comparison of amphibole particles from El Dorado Hills, California, to tremolite cleavage fragments and tremolite asbestos analyzed. 


\section{Tables}

1. Ideal end-member chemical compositions of the commonly regulated asbestos

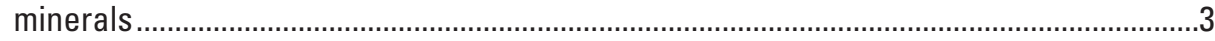

2. Summary of analytical methods used to analyze sample media collected by the U.S. Geological Survey from the El Dorado Hills, California, area......................................6

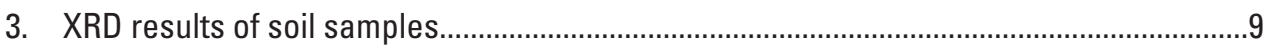

4. Phases observed in polished thin section by electron probe microanalysis. Major, minor, and trace designations represent the frequency with which the indicated phases were encountered....

5. Representative analyses of amphibole using electron probe microanalysis with wavelength dispersive spectrometry

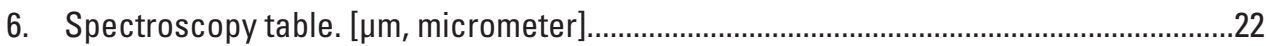




\section{Executive Summary}

At the request of the U.S. Environmental Protection Agency (USEPA), the U.S. Geological Survey (USGS) has conducted an independent study of amphiboles in rocks and soils in the El Dorado Hills, California, area. The purpose of this study is to investigate specific issues regarding the presence of "naturally occurring asbestos" raised by an USEPA activity-based sampling study and subsequent criticisms of that study outlined in a review prepared by The R.J. Lee Group (RJLG). In their review, the RJLG challenged results of the USEPA study and suggested that the materials identified as asbestos by USEPA and its contract analytical laboratories do not meet the definitions of asbestos for the purposes of regulation and therefore should not be considered as a potential public health concern. The RJLG report suggested that amphibole asbestos was not present in USEPA's samples because (1) approximately 60 percent of the particles had too much aluminum to form asbestiform amphibole, (2) aspect ratios (length to width) of the particles did not represent a population of asbestos fibers, and (3) optical properties of the particles are not consistent with asbestos particles.

For this study, samples from bedrock outcrops and soils were collected in the El Dorado Hills study area by USGS scientists and were analyzed by a variety of techniques in order to define chemistry, mineralogy, and mineral morphology. The amphibole particles collected were also compared to amphiboles collected on air filters by the USEPA during activity-based sampling in and around the Community Recreation Facilities and along the New York Creek Trail in El Dorado Hills. The principal findings of this USGS study are the following:

- The vast majority of amphiboles in the study area are classified as actinolite, magnesiohornblende, and tremolite (in decreasing order of abundance) based on electron probe microanalysis, using the nomenclature of Leake and others (1997). Classification of these mineral types is based on chemistry and is independent of morphology.

- Tremolitic amphibole particles occur primarily in ultramafic rocks exposed (1) on and adjacent to Oak Ridge and (2) in small outcrops in Fairchild Park. These particles commonly occur in a fibrous morphology that locally grades to asbestiform. Therefore, material that can be classified as tremolite asbestos is locally present in the USGS study area. Chrysotile asbestos was also found in at least two samples in this study and in several samples in the USEPA study. The presence of chrysotile in the study area was not an item of contention in the RJLG review.

- The actinolite-magnesiohornblende particles occur primarily in a prismatic to acicular habit. These particles appear to be primarily weathered single crystals. These amphiboles are generally associated with mafic metavolcanic and metasedimentary rocks exposed along the New York Creek Trail and other parts of the study area. Some of these particles do exhibit a fibrous habit that falls short of being asbestiform by commercial definitions. However, many of these particles do fall within the counting rule requirements specified in analytical methods used in the USEPA study.

- In general, aluminum content of amphiboles has not been demonstrated to systematically correlate with particle morphology as suggested by the RJLG review. Furthermore, it has been demonstrated in the literature that the optical property of extinction is not a consistent and reliable indicator of asbestiform morphology for tremolite-actinolite minerals. These issues are discussed, and citations supporting these arguments are provided in the body of the report.

- The amphibole particles in the rocks and soils collected for this study are similar in chemistry and morphology to the amphibole particles observed on selected air filters collected at comparable locations during USEPA's activity-based sampling study. 
- As a general observation, amphiboles in soils collected for this study are similar in chemistry and morphology to amphiboles that were observed in adjacent rock outcrops, suggesting that the amphiboles in the soils are largely derived from local weathering rather than from transport by wind or water.

- A comparison of the amphibole particle aspect ratio data from this study with data from published tremolite asbestos and cleavage fragment (prepared by milling massive tremolite) populations indicates that the El Dorado Hills amphiboles have dimensions between the two morphological types. The El Dorado Hills amphiboles clearly do not fit a population of cleavage fragments and have fewer high-aspect-ratio particles than a population of asbestos particles.

In summary, many of the amphibole particles examined in this study meet the counting rule criteria used by USEPA from both chemical and morphological requirements. However, most of these particles do not meet the morphological definitions of commercial-grade asbestos. Fibrous to asbestiform tremolite was identified in ultramafic rocks exposed locally at a few sites in the study area. Determining the abundance of the fibrous and asbestiform amphibole occurrences in the El Dorado Hills area is well beyond the scope of this study. Such a study, if deemed necessary by the stakeholders, should be conducted by local health officials in collaboration with local geologists and mineralogists.

In this report the USGS does not equate definitions of commercial asbestos properties, or lack thereof, with toxicity. Based on the current level of understanding in the asbestos community, it is not clear that toxicity strictly correlates with only the commercial or regulated forms of asbestos (National Institute for Occupational Health and Sciences, 2002). Thus it is difficult to define the "asbestos" content in the El Dorado Hills area from a health perspective. Ultimately, it is the health community that must determine what particles types are significant with respect to asbestos-related diseases. Therefore, a collaborative research effort is needed by the health community, with assistance from experienced mineralogists and analysts, to develop a better understanding of potential health effects of what is currently called "naturally occurring asbestos." 


\title{
Mineralogy and Morphology of Amphiboles Observed in Soils and Rocks in El Dorado Hills, California
}

\author{
By G.P. Meeker, H.A. Lowers, G.A. Swayze, B.S. Van Gosen, S.J. Sutley, and I.K. Brownfield
}

\section{Introduction}

At the request of U.S. Environmental Protection Agency (USEPA), Region 9, the U.S. Geological Survey Denver (USGS) Microbeam Laboratory has conducted a limited independent study of the geological materials, mineralogy, and other factors relating to the USEPA Region 9 study entitled "El Dorado Hills Naturally Occurring Asbestos Multimedia Exposure Assessment, El Dorado Hills, California." This USEPA report has been the subject of criticism by certain stakeholders who disagree with USEPA's conclusions regarding the presence of naturally occurring asbestos identified during activity-based air sampling and in sampling of soils in the study area in and around El Dorado Hills, California (fig. 1). The primary criticisms of the USEPA report are outlined in a report prepared by the R.J. Lee Group (RJLG) and funded by the National Stone Sand and Gravel Association (NSSGA) (R.J. Lee Group, Inc., 2005).

The purpose of this USGS study is to investigate specific issues raised by the RJLG report. In their report, RJLG challenged results of the USEPA study and suggested that the materials identified as asbestos by USEPA and its contract analytical laboratories do not meet the definitions of asbestos for the purposes of regulation and therefore should not be considered a public health concern.

The specific issues of controversy surrounding USEPA's report involve the question of what should be considered "asbestos" in contrast to what should be considered normal airborne particulate mineral material, the latter implying material with little or no health risk.

To address these issues, the USGS conducted field sampling and performed a geologic and mineralogic evaluation of the materials in question. In addition, this study has relied on reviews of existing literature, soils reports, and geologic reports. This study also relied on the California Geological Survey (CGS) for assistance in identifying appropriate sampling locations and understanding the geology of the study area. This study does not include any evaluation of risk or health-related issues. The USEPA funded this independent study under USGS-USEPA interagency agreement DW1492190501-2.

\section{Background}

The USEPA report "El Dorado Hills Naturally Occurring Asbestos Multimedia Exposure Assessment, El Dorado Hills, California" (Ecology and Environment, Inc., 2005), referred to herein as "The USEPA Study," reported elevated levels of asbestos minerals, namely tremolite-actinolite and chrysotile, in air samples collected during activity-based sampling when compared to air ambient samples collected at approximately the same times and locations. Some of the activity-based samples reportedly contained 40 times the levels of asbestos observed in the ambient samples (Ecology and Environment, Inc., 2005). Activities included a simulated baseball game in El Dorado Hills Community Park and hiking and bicycle riding on the New York Creek Trail. The levels reported were not intended to show levels above a health-based benchmark, but were intended to show activity based levels of personal exposure relative to ambient or background levels for the area. The fiber counting rules employed in The USEPA Study were based on ISO 10312 for air samples to determine phase contrast microscopy equivalent (PCME) counts. The laboratories were instructed to use a greater than or equal to 3:1 aspect ratio for counting of structures in air samples, as allowed in Annex $\mathrm{C}$ in ISO 10312. Otherwise, laboratories were instructed to count fibers based on the normal counting rules outlined in the methods specified in The USEPA Study. Those dimensional counting criteria were $5 \mu \mathrm{m}$ (micrometer) length, 0.25 to $3 \mu \mathrm{m}$ width, and an aspect ratio (length to width) of 3:1 or greater.

Following the release of The USEPA Study, the RJLG was hired by the NSSGA to review The USEPA Study. This review report entitled "Evaluation of USEPA's Analytical Data from the El Dorado Hills Asbestos Evaluation Project," referred to herein as "The RJLG Review," criticized several aspects of The USEPA Study, particularly regarding identification of asbestos and application of counting protocols. According to The RJLG Review, essentially none of the particles counted in The USEPA Study should have been counted as asbestos. The reasons provided in The RJLG Review included the following: (1) 63 percent of the particles contained more than 0.3 cation of aluminum in the structural formula and therefore cannot be asbestos, (2) the remaining particles did 


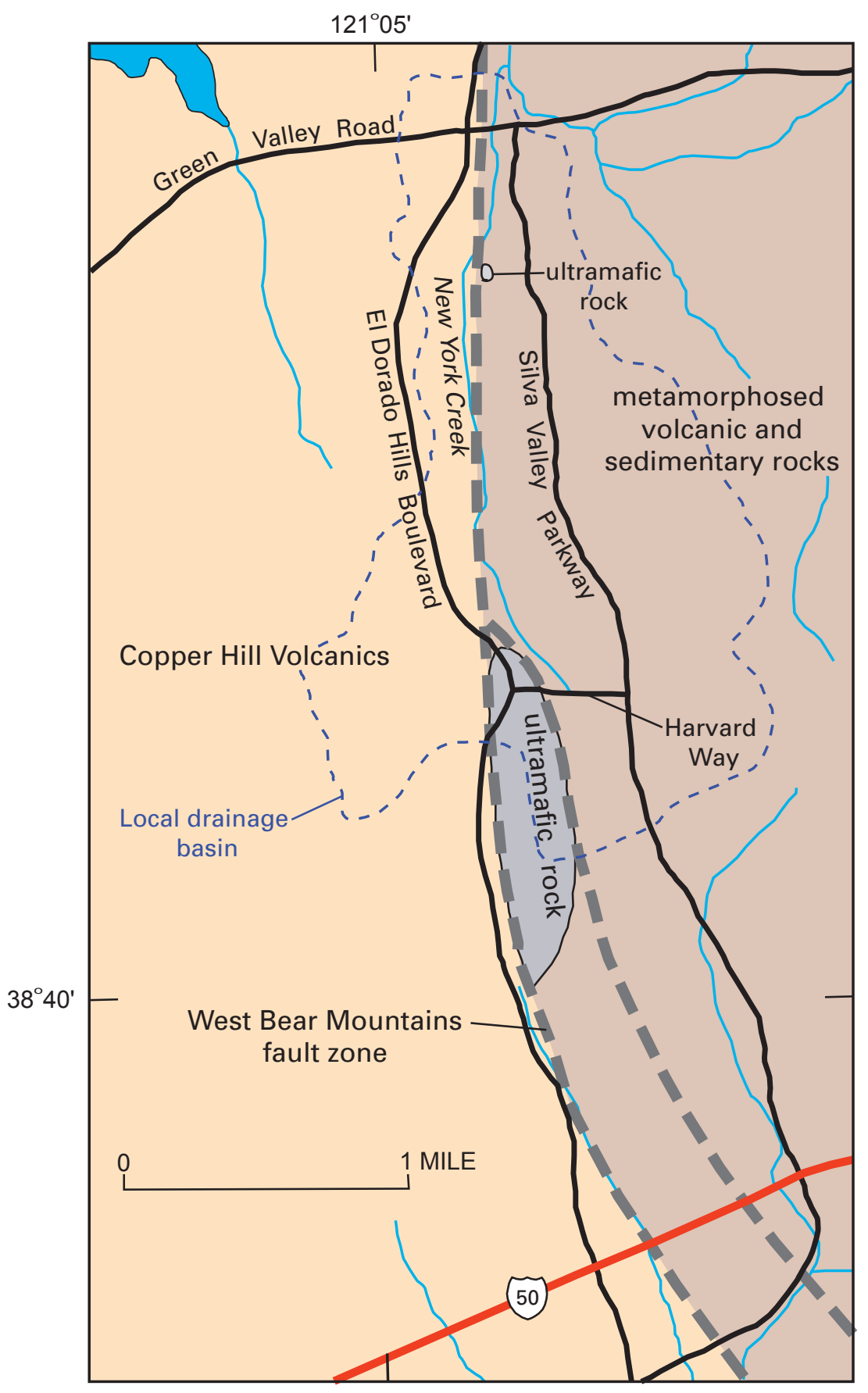

Figure 1. Generalized geologic map of the El Dorado Hills community, adapted from Churchill and others (2000). The West Bear Mountains fault zone (dark gray dashed lines) is approximately located. Its exact location is uncertain due to minimal rock outcrop in the valley, but the fault is thought to roughly coincide with the course of present-day New York Creek. 
not show zero degree pseudoextinction angles (parallel extinction) using polarized light microscopy (PLM) and therefore cannot be asbestos, (3) the populations of the particles identified did not represent a population of asbestos fibers but rather represented a population of mineral cleavage fragments, and (4) counting protocols as outlined in the analytical methods were not properly followed.

In early 2006 the USGS was asked by USEPA, Region 9, to investigate the issues identified in items 1,2 , and 3 above because these issues are based primarily on mineralogy and geology, and by extension these issues are linked to natural rock sources. The primary objective of this study is to determine the composition, morphology, and source of the amphibole mineral particles in question. The USGS agreed to undertake this task under the condition that USGS would conduct an independent study, which included new sampling of the materials in question by USGS personnel with assistance from geologists from the CGS. Also, the USGS would determine the appropriate analytical methods to address the questions at issue, and the USGS would have complete control of the results and interpretations presented in a final report delivered to USEPA. The USEPA agreed to all of the conditions, and the USGS began the study in April 2006.

\section{Geologic Setting of El Dorado Hills}

\section{Ultramafic Rocks, Mafic Rocks, and Asbestos}

As described by Churchill and others (2000) and Clinkenbeard and others (2002), ultramafic igneous rocks and some mafic igneous rocks are the common hosts for the known asbestos occurrences in northern California. Ultramafic rocks are dark igneous rocks composed of 90 weight percent or more mafic minerals, which are dark iron-magnesium-silicate minerals, such as olivine, amphiboles, and pyroxenes. Mafic minerals are sometimes referred to as ferromagnesian minerals. Mafic rocks are also dark-colored igneous rocks because they typically have mafic mineral contents of 50 to 89 weight percent. The iron- and magnesium-rich mineralogy of ultramafic rocks and some mafic rocks makes them ideal hosts for asbestos formation because they provide most of the chemical components needed to form asbestos. All of the commonly regulated asbestos minerals (table 1) contain magnesium, silica, and hydroxyl as essential components. Iron and calcium are also major constituents of some of the asbestos minerals, such as those in the tremolite-ferro-actinolite solid solution series (table 1). Certain geological conditions can cause an influx of heated waters that carry silica dissolved in solution into an ultramafic or mafic rock where these fluids can react with and chemically replace the mafic minerals in the rock, sometimes forming asbestos. When heated silica-rich fluids react with the mafic minerals, the system has been provided with the chemical ingredients necessary to form asbestos minerals. However, the proper pressure and temperature requirements must also be met within the local system for asbestos to form (fibrous mineral growth). The alteration of ultramafic rocks typically forms serpentinite, a rock composed primarily of the serpentine group minerals antigorite, lizardite, and sometimes chrysotile (Faust and Fahey, 1962). The very presence of serpentinite in an outcrop indicates that the chemical conditions were suitable for asbestos mineral formation; however, other physical conditions must be met for asbestos fibers to grow, including conditions that may occur at a microscopic scale.

Table 1. Ideal end-member chemical compositions of the commonly regulated asbestos minerals. Amphibole cation ratios from Leake and others (1997).

Mineral

End-member cation ratios
Serpentine group

Chrysotile

Amphibole group

Asbestiform riebeckite

("crocidolite")

Asbestiform cummingtonite-grunerite

("amosite")

Asbestiform anthophyllite

Asbestiform actinolite

Asbestiform tremolite

$$
\mathrm{Mg}_{3} \mathrm{Si}_{2} \mathrm{O}_{5}(\mathrm{OH})_{4}
$$

$$
\begin{gathered}
\square \mathrm{Na}_{2}\left(\mathrm{Mg}, \mathrm{Fe}^{2+}\right)_{3} \mathrm{Fe}^{3+}{ }_{2} \mathrm{Si}_{8} \mathrm{O}_{22}(\mathrm{OH})_{2} \\
\mathrm{Mg} /\left(\mathrm{Mg}^{2} \mathrm{Fe}^{2+}\right)<0.5 \\
\square \mathrm{Mg}_{7} \mathrm{Si}_{8} \mathrm{O}_{22}(\mathrm{OH})_{2} \text { to } \mathrm{Fe}^{2+}{ }_{7} \mathrm{Si}_{8} \mathrm{O}_{22}(\mathrm{OH})_{2} \\
\square\left(\mathrm{Mg}, \mathrm{Fe}^{2+}\right)_{7} \mathrm{Si}_{8} \mathrm{O}_{22}(\mathrm{OH})_{2} \\
\mathrm{Mg} /\left(\mathrm{Mg}^{2+\mathrm{Fe}^{2+}}\right) \geq 0.5 \\
\square \mathrm{Ca}_{2}\left(\mathrm{Mg}, \mathrm{Fe}^{2+}\right)_{5} \mathrm{Si}_{8} \mathrm{O}_{22}(\mathrm{OH})_{2} \\
\mathrm{Mg} /\left(\mathrm{Mg}^{2+} \mathrm{Fe}^{2+}\right)=0.5-0.89 \\
\square \mathrm{Ca}_{2}\left(\mathrm{Mg}, \mathrm{Fe}^{2+}\right)_{5} \mathrm{Si}_{8} \mathrm{O}_{22}(\mathrm{OH})_{2} \\
\mathrm{Mg} /\left(\mathrm{Mg}^{2} \mathrm{Fe}^{2+}\right)=0.9-1.0
\end{gathered}
$$

$\square$, Empty "A" site in the amphibole structure. 
Fracturing, faulting, shearing, and associated microfracturing accompanied by relatively moderate fluid temperatures and pressures are thought to be other important factors in asbestos formation. Initially, the fracturing likely promotes serpentine development by providing conduits and permeability for heated fluids to flow through the ultramafic body (Cady and others, 1963; Chidester and others, 1978). In the formation of chrysotile (asbestiform serpentine), and probably also in the formation of amphibole asbestos, microfractures in the ultramafic host rock likely play an important role (Evans, 2004). The microfractures allow room for mineral fibers to grow, while simultaneous microscopic stresses may encourage crystal growth in a preferred direction. Such growth is typical of asbestos. Processes of regional-scale metamorphism driven by plate tectonics were the likely mechanism for the heat, pressure, and fluid flow that formed most of the serpentine, chrysotile, and tremolite-actinolite asbestos found within metamorphosed ultramafic rock bodies of western El Dorado County (Churchill and others, 2000).

\section{Regional Setting}

The El Dorado Hills community occupies a small part of a large north-northwest-trending geologic province referred to as the Western Sierra Nevada Metamorphic Belt (WSNMB) of the western Sierra Nevada foothills region of northern California. The WSNMB, roughly 250 miles long by 50 miles wide, is composed mainly of metamorphosed sedimentary and igneous rocks that are Paleozoic and Mesozoic in age (Clark, 1964, 1976; Schweickert and others, 1999). This belt has a complex geologic history. These rocks began as seafloor rocks and sediments, continental sediments, volcanic rocks, and igneous intrusions, which were subsequently metamorphosed (recrystallized under high heat and pressure) by the collisions of tectonic plates approximately 160 to 300 million years ago along the western margin of the North American continent. A detailed description of the geology and evolution of the WSNMB is provided by Schweickert and others (1999).

The WSNMB is characterized by long north-to-northwest-trending fault zones that separate large packages of rock sequences called terranes (see Wagner and others, 1987; Schweickert and others, 1999). These distinct terranes are thought to have formed as the oceanic tectonic plate collided with, and moved under (was subducted by), the North American tectonic plate (the continental land mass) during the late Paleozoic and early to middle Mesozoic eras (about 160 to 300 million years ago) (Schweickert and others, 1999). In the El Dorado Hills area, terranes of the WSNMB are separated by the West Bear Mountains fault zone (fig. 1).

During plate tectonic movements of the Mesozoic era, the WSNMB was locally intruded by magmas. This formed igneous rock bodies that range in size from small intrusions (dikes and sills on the order of a foot in width) up to large complex plutons, such as the $40 \mathrm{mi}^{2}$ Pine Hill Intrusive Complex about 3 miles east of the El Dorado Hills community. The Pine Hill Intrusive Complex, about 165 million years old, is composed primarily of gabbro, a mafic rock similar in chemical composition to Hawaiian volcanic lavas (basalt); however, the Pine Hill magmas cooled and solidified before reaching the Earth's surface. A detailed study and description of the Pine Hill Intrusive Complex was conducted by Springer (1971) and its extent is shown on maps by Springer (1971), Wagner and others (1987), and Churchill and others (2000).

\section{Geology of the El Dorado Hills Area}

Metamorphosed ultramafic igneous rocks form the bulk of Oak Ridge (fig. 1), the hillside and ridge that extends about 11/4 miles southward from Harvard Way, flanked by El Dorado Hills Boulevard on the west and Silva Valley Parkway on the east. Thin layers of metavolcanic and metasedimentary rocks are interspersed with the ultramafic rock bodies that make up Oak Ridge. In the El Dorado Hills area, the West Bear Mountains fault zone likely provided the fracturing and microfracturing that locally enhanced serpentine formation in this rock unit rock. Metamorphosed ultramafic rocks within this rock unit are locally altered to lenses and pods of serpentinite rock. Examples are exposed near the crest of Harvard Way and along Woedee Drive. Churchill and others (2000) considered this ultramafic rock unit as the unit most likely to host asbestos in the El Dorado Hills area.

The West Bear Mountains fault zone can only be approximately projected through the El Dorado Hills community because in this valley the rock exposures are small and sporadic. The fault zone, from Harvard Way northward to Green Valley Road, is thought to generally coincide with the present-day course of New York Creek (fig. 1), but its precise location is uncertain. The fault zone separates the Copper Hill Volcanics on the west from an unnamed sequence of metamorphic rocks on the east, and the fault zone also bounds the ultramafic rock body that forms the prominent ridge south of Harvard Way (see fig. 1, adapted from Churchill and others, 2000).

A north-trending portion of the West Bear Mountains fault zone separates three rock terranes in the El Dorado Hills community (fig. 1); these terranes are composed of:

- Rocks of the Jurassic-age Copper Hill Volcanics, west of the fault zone (generally west of New York Creek);

- Unnamed metamorphosed mafic volcanic rocks of unknown age and interlayered metamorphic sedimentary rocks, east of the fault zone (east of New York Creek); and

- A rock unit dominated by metamorphosed ultramafic igneous rocks; this rock unit forms the prominent ridge (Oak Ridge) that extends south from Harvard Way, between El Dorado Hills Boulevard and Silva Valley Parkway. A much smaller exposure of metamorphosed rock outcrops in Fairchild Park approximately 0.4 mile south of Green Valley Road. 
The Copper Hill Volcanics are a sequence of metamorphosed mafic volcanic rocks named by Clark (1964, p. 30-31), which he describes as "mainly pyroclastic rocks, probably mostly andesitic." Clark (1964) suggests that the bulk of this formation formed from explosive eruptions of andesitic volcanoes (perhaps some basaltic) about 159 to 151 million years ago, which deposited multiple layers of this airborne volcanic ash. A much smaller amount of the formation is composed of lava flows, as well as scattered, small igneous intrusions (sills). The entire volcanic sequence of this formation was later weakly metamorphosed (greenschist facies) by the heat and pressure effects of Mesozoic plate tectonics. In the El Dorado Hills area, the uppermost layers of the Copper Hill Volcanics were truncated by the West Bear Mountains fault zone.

The unnamed sequence of weakly metamorphosed volcanic and sedimentary rocks on the east side of the West Bear Mountains fault zone in the El Dorado Hills area are described by Clark $(1964,1976)$. These rocks are primarily "green schist" composed mainly of metamorphosed mafic volcanic (explosion) breccias and tuffs. Occasional thin beds in the greenschist are metamorphosed mudstones, siltstones, and sandstones. Springer (1971, p. 37) states that "microscopically the greenschist contains chlorite, equant grains of epidote, acicular actinolite, albite (?), and accessory iron oxides and apatite." This volcanic rock-sedimentary rock sequence is thought to have formed near the western edge of the North American continent during the late Paleozoic or early Mesozoic. The volcanic deposits and sediments may have originally been deposited both on the ocean floor and on the adjacent land mass. Subsequent metamorphism (greenschist facies) of these rocks due to the heat and pressure of plate tectonics has made the original characteristics of the rocks difficult to decipher.

\section{Methods}

Several analytical methods were employed to prepare and characterize the samples collected in the El Dorado Hills area. These analytical techniques included $\mathrm{x}$-ray diffraction analysis (XRD), scanning electron microscopy with energy dispersive $\mathrm{x}$-ray spectroscopy (SEM/EDS), and electron probe microanalysis utilizing wavelength dispersive $\mathrm{x}$-ray spectroscopy (EPMA/WDS). In addition, visual and infrared reflectance spectroscopy analysis was performed on collected samples in order to understand the relationships between rock and soil types, amphibole (and chrysotile) fiber content, and spectroscopy measurements. These data could potentially provide helpful information for future reconnaissance surveys in similar rock types. A brief description of these analytical techniques and the strengths and weaknesses of each are given in table 2 .

\section{Sample Collection}

Sampling strategy for this study focused on those areas where The USEPA Study detected significant levels of amphibole. In The USEPA Study, chrysotile was detected primarily in the baseball fields of El Dorado Community Park. Our study did not address baseball fields in detail and does not include SEM/EDS or EPMA/WDS analyses of these soil samples because chrysotile was not an issue in The RJLG Review and because the soils on the ballfields were imported materials and not indigenous (personal commun., USEPA, 2006). Results of XRD and reflectance spectroscopy analyses of ballfield samples are provided below.

Samples of soil, stream sediment, rock, and settled dust residue were collected from the El Dorado Hills area during April 18 - 20, 2006. Locations where these samples were collected are shown in Appendix A, figure A1. Soil samples were collected along and adjacent to the New York Creek (NYC) Trail, baseball fields, local outcrops, tributaries to NYC, a nearby abandoned chromite prospect on Oak Ridge, and at Fairchild Park. Collection of soil samples was done with a 3 inch $(7.6 \mathrm{~cm})$ diameter, chrome-plated bucket auger with a 6.5 inch $(16 \mathrm{~cm})$ long bucket. Samples were collected at approximately 3 to 4 inch $(8$ to $10 \mathrm{~cm})$ depth increments until either approximately a 1 foot depth was sampled, bedrock was reached, or until cobbles were encountered (fig. 2). Depth ranges were recorded for each soil sample increment. For each depth increment, contents of the auger bucket were emptied onto the surface of a clean plastic garbage bag and then transferred with a clean, stainless steel trowel into individual plastic bags (fig. 2). Only the top few inches of soil were collected on the baseball fields so as not to disturb the playing surface. GPS coordinates were recorded for each drill hole (WGS84 datum) and the site was documented (Appendix A; fig. A1, table A1). The soil auger was washed with water and a stiff-bristle brush prior to use at each drill hole to avoid cross contamination.

Samples of active stream sediment were collected from NYC adjacent to several of the soil drill holes. Clean plastic scoops were used to collect samples of stream sediment from a few square meters area of the adjacent, underwater portion of the creek bed. These randomly collected samples were placed in pint-sized plastic jars.

Rock samples were collected from accessible outcrops along NYC and its tributaries east of Silva Valley Parkway, south of Harvard Way, south of the Community Recreation Center, west of El Dorado Hills Boulevard, at Fairchild Park, and at an abandoned chromite prospect on Oak Ridge. After collection the rock samples were placed in plastic bags. Stream, rock, and soil samples were collected as sets in order to understand weathering patterns where possible.

Settled dust residue samples were dabbed onto doublestick carbon tape on aluminum SEM stubs from fence railings at the Community Park playground; the south baseball-field vending machine enclosure and equipment locker roof; the NYC baseball field third base dugout and home plate; a storage shed just south of the NYC baseball field; a building near the community park pool; and the top of an electrical box on the south side of the Community Recreation Center building. Sampling was done by gently touching the SEM stub to the dust on the upward facing surface of the sampled structure. 
Table 2. Summary of analytical methods used to analyze sample media collected by the U.S. Geological Survey from the El Dorado Hills, California, area.

\begin{tabular}{|l|l|l|l|}
\hline Method & Instrument & Optimized for: & Drawbacks \\
\hline EPMA & $\begin{array}{l}\text { Electron probe microanalyzer } \\
\text { utilizing wavelength dispersive } \\
\text { spectroscopy }\end{array}$ & $\begin{array}{l}\text { Most accurate and precise } \\
\text { quantitative chemical analysis of } \\
\text { small (less than 2 micrometers) } \\
\text { spatially resolved areas. }\end{array}$ & $\begin{array}{l}\text { Requires flat polished surface for optimum analytical } \\
\text { results; operating conditions do not allow for high } \\
\text { resolution images. }\end{array}$ \\
\hline SEM & $\begin{array}{l}\text { Scanning electron microscopy } \\
\text { utilizing energy dispersive } \\
\text { spectroscopy }\end{array}$ & $\begin{array}{l}\text { 3-D imaging at high resolution } \\
\text { and high magnifications. Also } \\
\text { able to do semiquantitative } \\
\text { chemistry of individual particles. }\end{array}$ & $\begin{array}{l}\text { Errors in chemistry caused by particle geometry } \\
\text { can be as high as 20 percent relative concentration. } \\
\text { Analyses are generally normalized to 100 percent } \\
\text { so the quality of the analysis is often difficult to } \\
\text { determine. }\end{array}$ \\
\hline TEM & $\begin{array}{l}\text { Transmission electron micro- } \\
\text { scope using energy dispersive }\end{array}$ & $\begin{array}{l}\text { Morphological, semi-quantitative } \\
\text { chemical, and crystallographic } \\
\text { information on individual par- } \\
\text { ticles at magnifications of greater } \\
\text { than 20,000x. }\end{array}$ & $\begin{array}{l}\text { Sample thickness and high energy operating } \\
\text { conditions affect quality of chemical analyses. }\end{array}$ \\
\hline XRD & X-ray diffractometer & $\begin{array}{l}\text { Structural confirmation of } \\
\text { mineral phases present in bulk } \\
\text { sample. }\end{array}$ & $\begin{array}{l}\text { Need chemical analyses to thoroughly characterize } \\
\text { the amphibole mineral phases. }\end{array}$ \\
\hline VIRS & Visual and infrared spectroscopy & $\begin{array}{l}\text { Detection of individual absorption } \\
\text { features due to mineral specific } \\
\text { chemical bonds. }\end{array}$ & $\begin{array}{l}\text { Need chemical analyses and XRD to confirm } \\
\text { minerals present. The method is unable to distinguish } \\
\text { asbestiform from nonasbestiform morphologies. }\end{array}$ \\
\hline
\end{tabular}
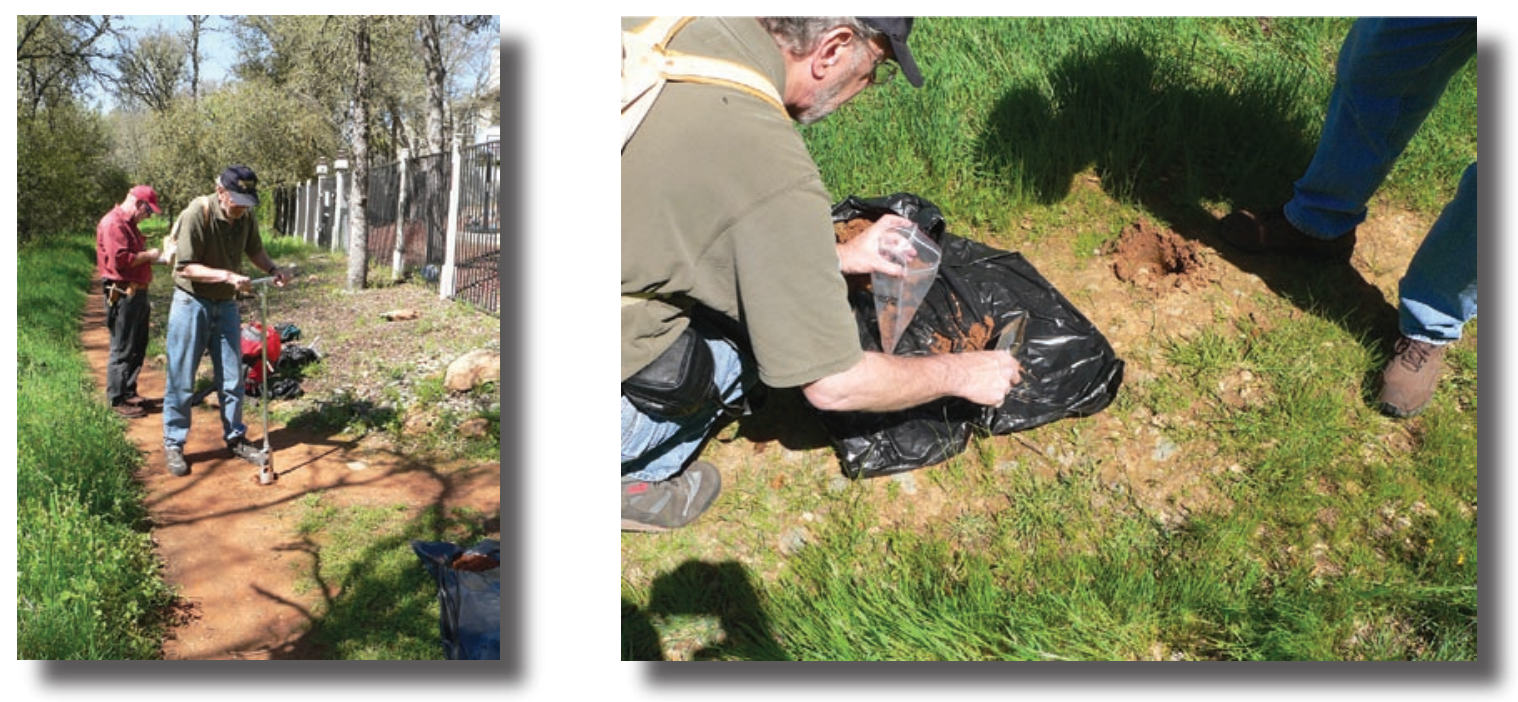

Figure 2. Soil collection procedure; see text for details. 


\section{Sample Preparation}

Soils were partially dried in their plastic sample bags in a fume hood for 2 days. The contents of each soil sample bag were then spread into precleaned stainless steel pans and disaggregated by hand in order to avoid crushing, which could change the physical character of any materials of interest. After disaggregation, soil samples were allowed to completely dry for another 2 to 3 days. Visible to infrared reflectance spectra of the completely dry soil samples were measured. The soil samples were then sieved through a 10 mesh (2 $\mathrm{mm}$ ) sieve, and the less than $2 \mathrm{~mm}$ fraction was split into two aliquots by using a Jones Precision Riffle Splitter following established soil-sampling protocol (Burt, 2004). One sample aliquot was archived and the other re-split for use in X-ray diffraction and SEM/EDS analyses. For SEM/EDS analysis, soil samples were sieved through a $250 \mu \mathrm{m}$ (60 mesh) sieve, then the samples were split using a Jones Precision Riffle Splitter to obtain a 0.5 -gram split. The 0.5 gram split was put into 100 milliliters deionized water and stirred with a magnetic stirring device. A 100 microliter aliquot of each sample was collected while the water was stirred on a separate $0.4 \mu \mathrm{m}$ pore diameter polycarbonate filter. After drying, the filter samples were coated using a carbon evaporator to make their surfaces conductive for SEM/EDS analysis.

Stream sediment samples were sieved, and the less than $63 \mu \mathrm{m}$ fraction was analyzed by $\mathrm{x}$-ray diffraction and inductively coupled plasma mass spectrometry (ICP-MS) and inductively coupled plasma atomic emission spectrometry (ICPAES) elemental analyses. The results of the stream sample chemical analyses are not directly applicable to this study and will be reported separately in a subsequent publication dealing with regional trace element concentrations in soils.

Plastic bags containing rock outcrop samples were opened and allowed to air dry in a hood over a period of several days. Spectral measurements of the rocks were also collected at this time. Subsamples of these rocks were then prepared as polished thin sections for EPMA.

\section{X-ray Diffraction (XRD)}

X-ray diffraction uses a beam of x-rays to "map" the crystal structure of minerals. Minerals are uniquely identified by the distribution (wavelength) and relative intensities of $\mathrm{x}$-ray reflections produced during the analysis. The soil and rock samples were split to obtain about a 3 gram specimen that was representative of the bulk sample. Each specimen was then dry pulverized with a mortar and pestle to an average particle size of about 50-60 $\mu \mathrm{m}$. About 1 gram of the specimen was then packed in an aluminum sample holder and analyzed with a Scintag X-1 automated diffractometer fitted with a spinning sample holder using copper $(\mathrm{Cu})$ $\mathrm{K}$-alpha radiation. The sample was run at a power setting of $45 \mathrm{kV}$ (kilovolts) and $35 \mathrm{~mA}$ (milliamps) at a stepping size of 0.02 degree 2 -theta with a 1 second counting time from 4 degrees 2-theta to 60 degrees 2 -theta.

\section{Electron Probe Microanalysis (EPMA/WDS)}

Electron probe microanalysis (EPMA) using wavelength dispersive spectrometry (WDS) is the most accurate and precise analytical technique for determining chemistry of materials at the micrometer scale. For best results with EPMA it is necessary to analyze a flat, highly polished surface. For this reason, polished petrographic thin sections (27 X 46 millimeters) of representative rock samples were prepared. The thin sections were scanned using optical microscopy and representative areas were selected and analyzed with a JEOL 8900 electron probe microanalyzer operated at 15 kilavolts $(\mathrm{kV})$ and 20 nanoamperes (nA) beam current (cup). The EPMA beam diameter was set to spot mode (much less than $1 \mu \mathrm{m}$ ) except on beam sensitive phases, in which case the beam was defocused to 5 or $10 \mu \mathrm{m}$. Calibration was checked using wellcharacterized silicate and oxide standards. Replicate analyses of standards were within 2 percent relative error for major and minor elements. Appendix B contains locations on thin sections of the analyzed points.

\section{Scanning Electron Microscopy and Energy Dispersive Spectrometry (SEM/EDS)}

Scanning electron microscopy is the best analytical technique for obtaining high magnification, three dimensional images of small particles. Energy dispersive x-ray analysis can, simultaneously, provide semiquantitative chemistry of individual particles. A JEOL 5800-LV scanning electron microscope equipped with an Oxford ISIS energy dispersive system with an ultrathin window detector was used to examine the filtered samples. Operating conditions were $15 \mathrm{kV}$ accelerating voltage, 0.1-1.0 nA beam current (cup), and approximately 30 percent detector deadtime time for EDS analysis. Data reduction was performed using the Oxford ISIS standardless analysis package with the ZAF correction. All analyses were normalized to 100 percent. The ZAF corrections do not take into account particle geometry, which can introduce significant errors.

Each soil sample was randomly scanned at magnifications of 500 to 2,000 times magnification to identify amphibole (and chrysotile if present) particles. These particles were then documented with a photomicrograph (Appendix $\mathrm{C}$ ), and the length and width were recorded (Appendix D). Approximately 8 to 12 particles were documented from each sample. Additionally, EDS data were used to calculate cation ratios (Appendix D). Amphibole particles analyzed were primarily within the size range specified by ISO 10312 with the modifications adopted from Annex C. Most of the larger amphibole particles found were not thoroughly characterized. Instead, we concentrated on particles meeting the counting criteria used by USEPA in order to provide comparable data on particle types that would have been analyzed by the USEPA contract laboratories. Air filters supplied by the USEPA were also analyzed in this manner. 
An additional soil sample collected near the recreation center (ED06-07) was examined specifically to determine amphibole particle size distribution. This sample was imaged at 2,000 times magnification. The length and width of all amphibole particles with an aspect ratio of 3:1 or greater were recorded. If the amphibole contacted the left or top boundary of the image, it was not counted. If the amphibole particle contacted the right or bottom boundary of the image, the image was shifted so that the entire amphibole particle could be measured. Duplicate counting of amphibole particles that overlapped the image boundary was avoided by analyzing nonadjacent fields. Fields were analyzed until 300 or more amphibole sizes were recorded.

\section{Infrared Spectroscopic Examination (IR)}

There are a variety of electronic and vibrational processes that shape IR reflectance spectra of surface materials (Hunt, 1977). The electronic absorptions occur primarily from 0.1 to 1.35 microns, and vibrational absorptions occur primarily beyond $0.9 \mu \mathrm{m}$. Both spectral regions can be used to identify materials, although each provides spectral information originating from different mechanisms. Electronic absorptions arise from charge transfers and crystal field effects of the transition metals, conduction bands, and color centers. Vibrational absorptions arise from vibrational modes of molecular bonds, such as those of $\mathrm{OH}^{-}, \mathrm{H}_{2} \mathrm{O}$, and $\mathrm{CO}_{3}{ }^{2-}$. In this study we use overtone and combination band absorptions in the reflected light portion of the spectrum located within the 1.35 to $2.5 \mu \mathrm{m}$ region for mineralogic identification.

Infrared (IR) reflectance spectra of the soil and rock samples were measured in a fume hood with an Analytical Spectral Devices (ASD) Full Range Spectrometer ${ }^{\circledR}$ over the wavelength range from 0.35 to $2.5 \mu \mathrm{m}$ by using a halogen lamp for illumination and Spectralon ${ }^{\circledR}$ panel for reference (Clark and others, 1990; Swayze and others, 2006). The ASD spectrometer has $5 \mathrm{~nm}$ (nanometer) spectral resolution from 0.35 to $1.0 \mu \mathrm{m}$ and $11 \mathrm{~nm}$ spectral resolution from 1.0 to $2.5 \mu \mathrm{m}$. During sample preparation, each soil sample was spread to form a flat pile about 1 inch $(2.5 \mathrm{~cm})$ thick for spectral measurement. Twenty spectra of each sample were measured, using a 6 second integration time for each spectrum. The spectrometer optical fiber was held a few centimeters above the pile and moved constantly in an elliptical manner to spatially average the surface of all but the edges of the pile. Individual rock fragments were also measured spectrally by continuously moving the optic fiber, in order to spatially average measurements. Spectra were averaged for each sample and corrected to absolute reflectance. Interpretation of the reflectance spectra of soil and rock samples was done by comparison with spectra of well characterized mineral samples from the USGS spectral library and other spectral studies (Clark and others, 2003; Clark and others, 1990; Swayze and others, 2004).

\section{Results}

\section{X-ray Diffraction}

Qualitative mineralogy was determined for each soil and rock sample as major mineral phases (greater than 25 percent by weight), minor (5 to 25 percent), and trace (less than 5 percent). The detection limit for the analyses was approximately 1 to 2 weight percent. The phases identified by XRD are summarized in table 3 . The major mineral phases identified by XRD in most samples were albite and quartz. Minor mineral phases in most samples include vermiculite, amphibole, epidote, and clinoclore. Trace vermiculite is a common clay mineral weathering product in many rocks and soils. Typical trace mineral phases include muscovite, talc, dolomite, and microcline. Samples contained differing proportions of these phases with notable exceptions being GSNYT06-12, ED06-09A, and NYT5104100804 FG4 (USEPA soil sample), where amphibole is reported as a major constituent. All of the mineral phases identified by $\mathrm{XRD}$ are typical constituents of regionally metamorphosed mafic and ultramafic rocks. Definitions of mineral phases listed above and elsewhere are provided in the glossary.

Amphibole was found at some level in all samples analyzed. Routine XRD of bulk samples cannot generally distinguish among the amphibole species (such as tremolite, actinolite, magnesiohornblende), which are typically differentiated by chemical methods according to the amphibole nomenclature established by Leake and others (1997). For this reason, the term amphibole, and not specific species, is listed in table 3. Additionally, XRD cannot distinguish between morphological types such as prismatic and asbestiform varieties of the same mineral.

\section{Electron Probe Microanalysis/WDS}

Table 4 summarizes the phases observed in the polished thin sections of rock outcrop samples. Amphibole was not observed in rock samples ED06-01B1, ED06-04B2, ED0609B1, ED06-09B2, and ED06-12B. However, amphibole was detected in soil sample ED06-09A1 using XRD methods. It is possible that this particular soil sample represents depositional material from a wider compositional range of rocks than the rock analyzed by EPMA.

Figures 3 to 5 summarize the composition of feldspar, chlorite, and epidote grains that were analyzed. The feldspar is predominately albite with an average composition of $\mathrm{Ab} 97$ (albite 97 percent, anorthite 3 percent). A few K-feldspar (orthoclase) grains were also identified. The chlorite had an average $\mathrm{Mg} \#$ of $59\left(\mathrm{Mg} \#=\mathrm{Mg} / \mathrm{Mg}+\mathrm{Fe}^{2+}\right)$. Chlorite analyzed from samples GSNYT06-01B and GSNYT06-02B had significantly higher $\mathrm{Mg \#}$ of 76 . Epidote analyzed from all samples is clinozoisite. The assemblage chlorite+albite+epidote represents the greenschist facies metamorphism that is typical of the mafic rocks in the study area (Springer, 1971). 
Table 3. XRD results of soil samples. Amphibole has been set in bold for ease of location. NA $=$ not applicable.

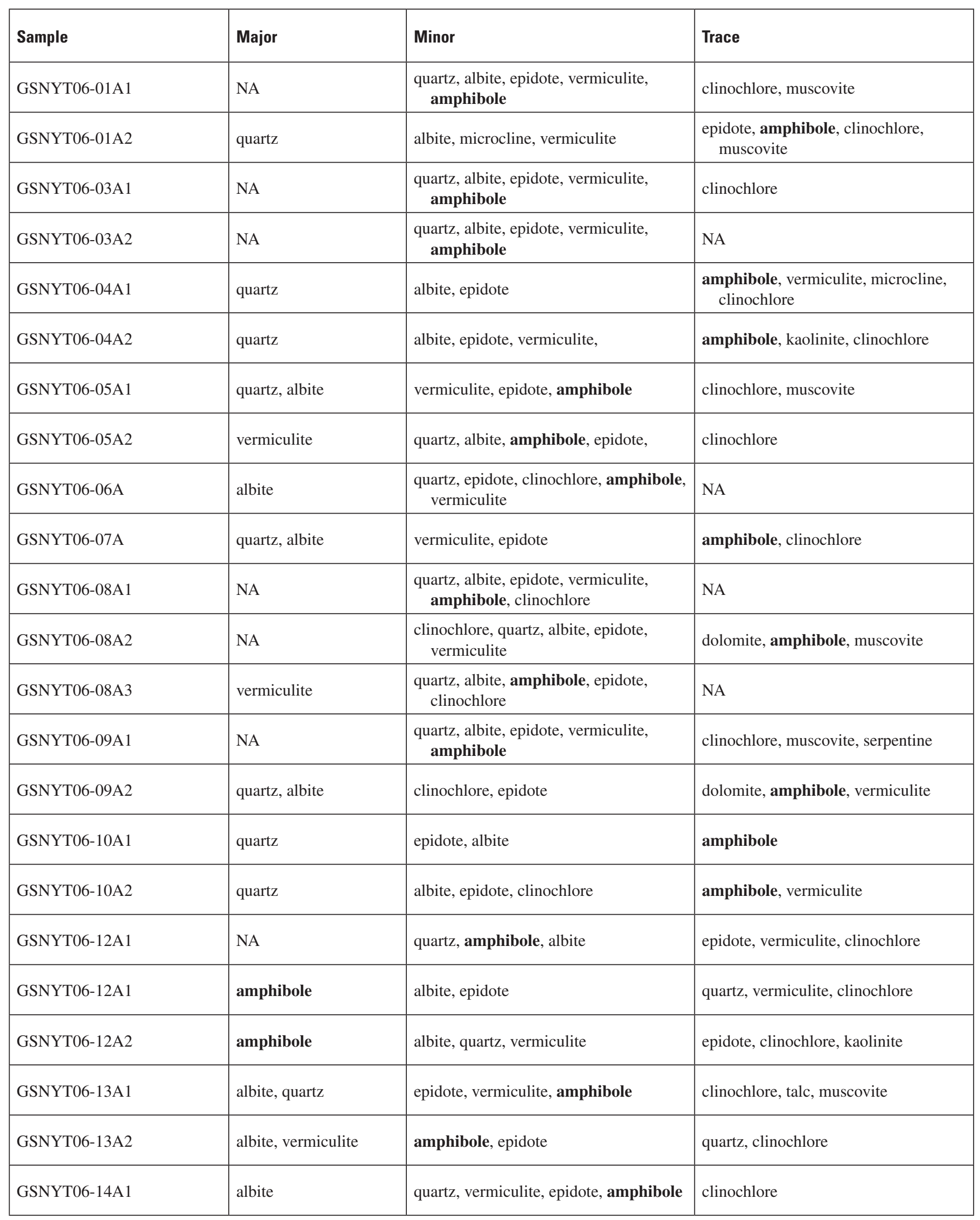


Table 3. XRD results of soil samples. Amphibole has been set in bold for ease of location. NA = not applicable.-Continued

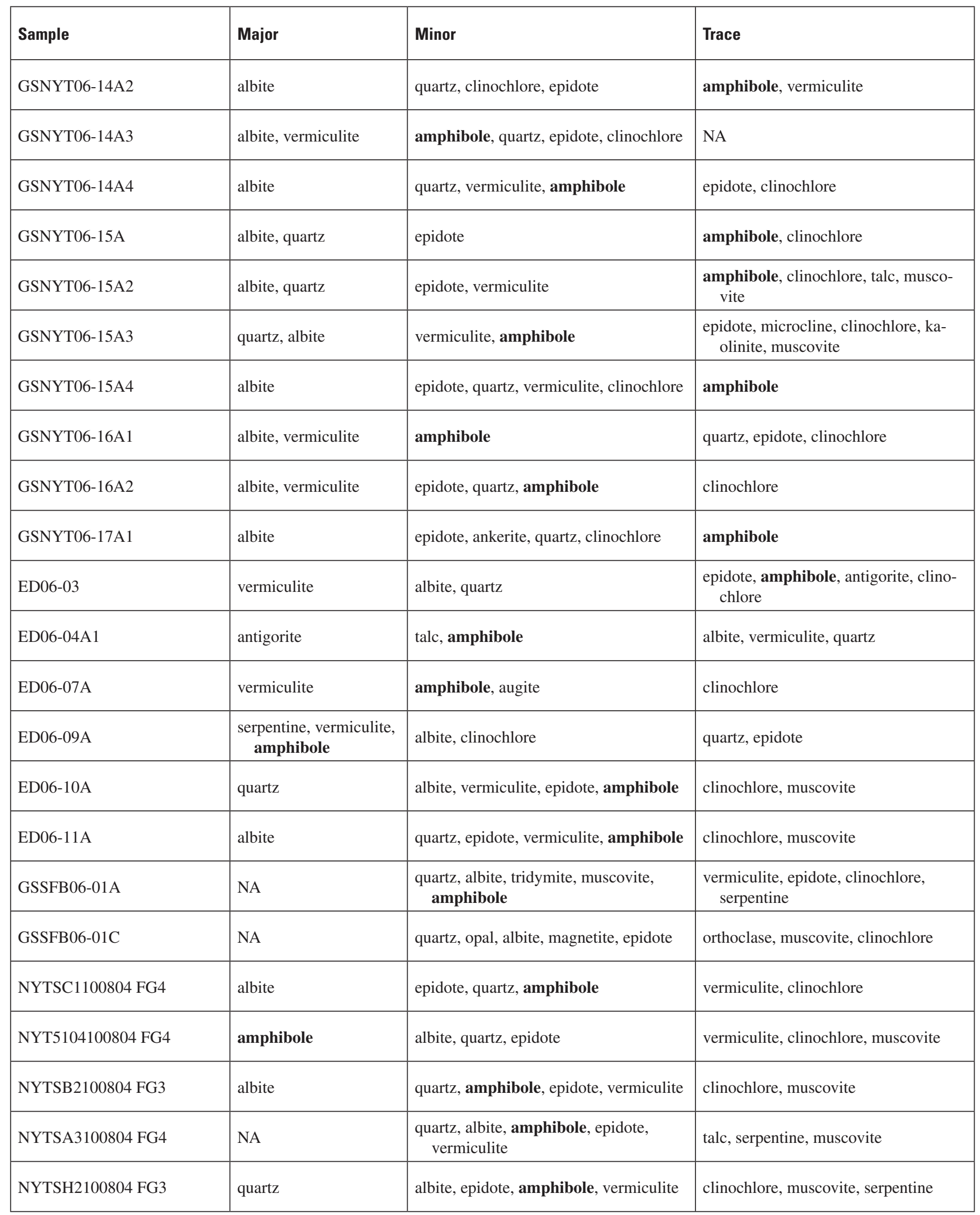


Table 4. Phases observed in polished thin section by electron probe microanalysis. Major, minor, and trace designations represent the frequency with which the indicated phases were encountered. It is not intended to be a quantitative assessment of the phase distribution.

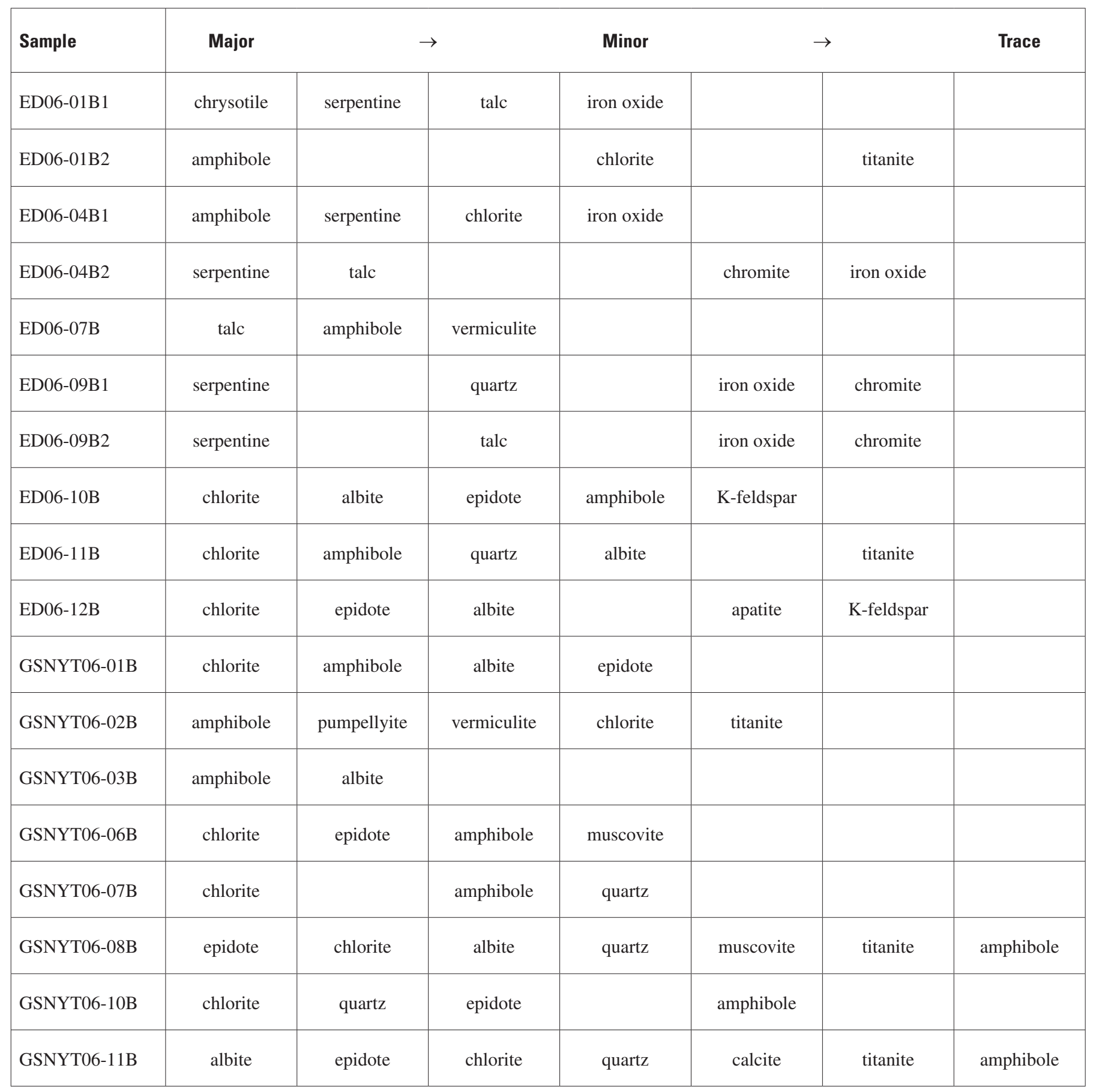




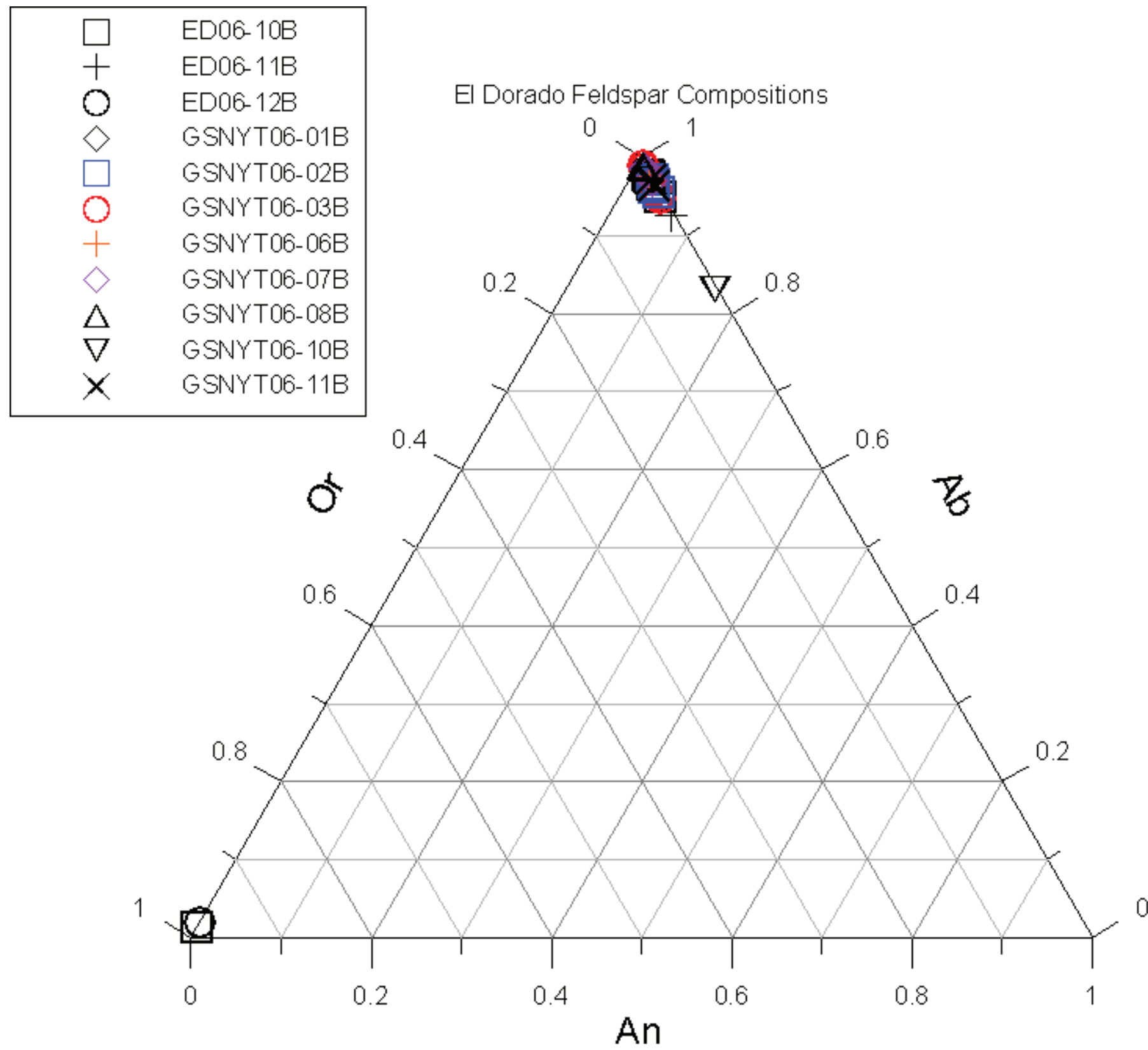

Figure 3. Composition of feldspars plotted on orthoclase (Or), albite (Ab), and anorthite (An) ternary.

Amphiboles observed in thin sections include tremolite, actinolite, and magnesio hornblende (fig. 6 and table 5). The method used to determine the ferrous/ferric iron ratios follows the recommendations of Leake and others (1997). Ferrous/ ferric iron ratios of some analyses could not be determined this way. For these analyses the $13 \mathrm{eCNK}, 15 \mathrm{eK}$, or $15 \mathrm{eNK}$ methods were used as described in Leake and others (1997). In an ideal case, the classification of the amphibole will not change with the method used to determine ferrous/ferric iron. However, it is possible that the classification of the amphibole will vary with method used to determine the ferrous/ferric iron ratios, as illustrated in Figure 7.

\section{Scanning Electron Microscopy/EDS}

Scanning electron microscopy with energy dispersive $\mathrm{x}$-ray spectroscopy was used to analyze amphiboles and other mineral phases in soils. Based on EDS analysis, all soil samples were composed primarily of chlorite, albite, epidote, quartz, and amphibole. Accessory phases such as chromite, iron oxide minerals, apatite, muscovite, and clay were also observed. Trace amounts of fibrous serpentine (chrysotile?) were also observed in samples ED06-09 and GSNYT06-07 (fig. 8). The mineral phases identified during SEM/EDS examination generally agree with XRD and spectroscopy results. 


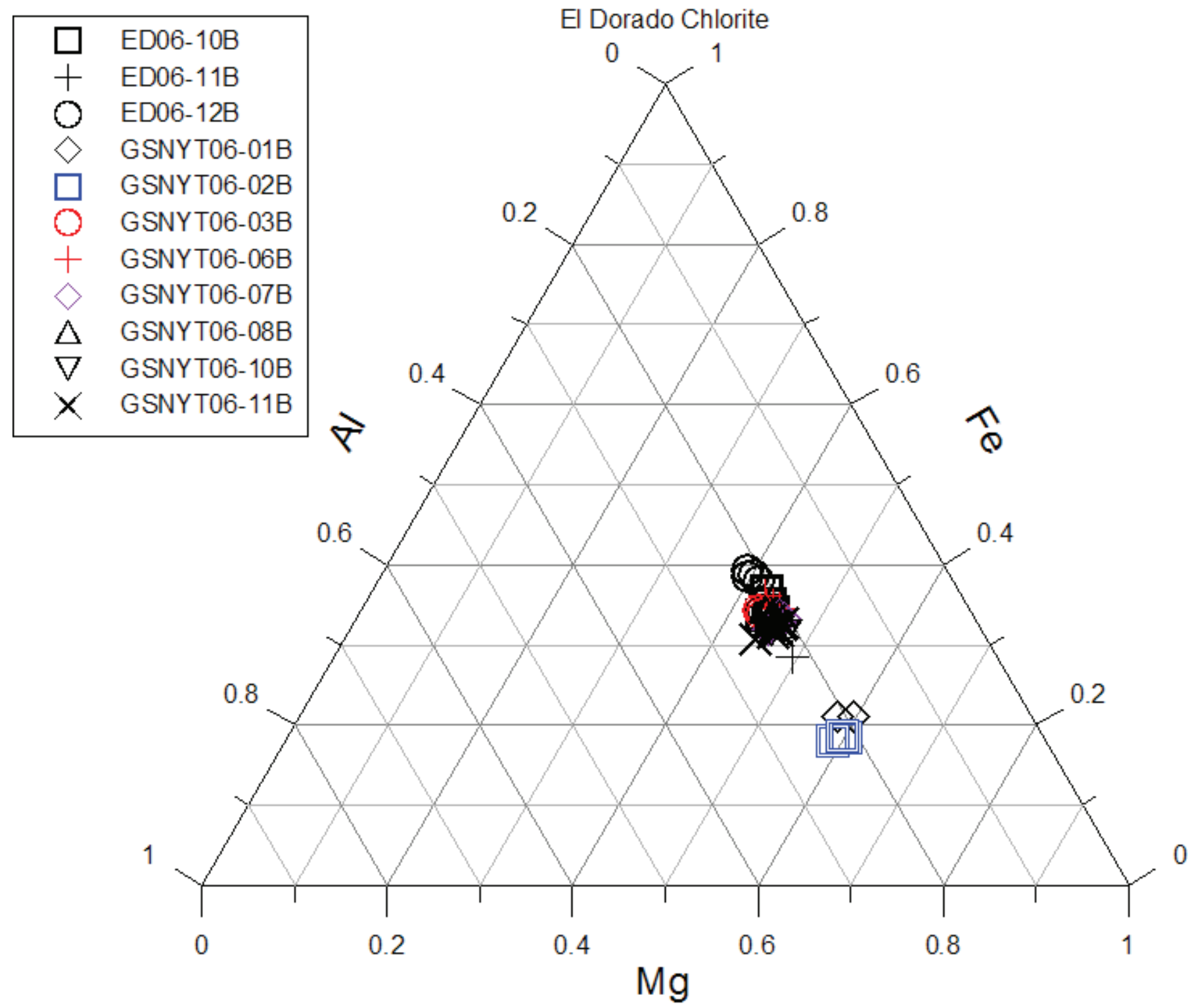

Figure 4. Composition of chlorite plotted on aluminum (Al), iron (Fe), and magnesium $(\mathrm{Mg})$ ternary.

The amphiboles identified using SEM/EDS techniques include tremolite, actinolite, magnesiohornblende, and very minor tschermakite (fig. 9). The weight percents of oxides acquired using the described operating and analysis conditions were converted to cations based on 23 oxygen equivalents. The cations were placed in the amphibole crystal sites based on the recommendations of the Leake and others (1997). However, the SEM/EDS data should not be considered quantitative, and the above classification is subject to some amount of analytical uncertainty. The amphibole classification scheme prescribed by Leake and others (1997) is based on precise mineral chemistry typically gathered by EPMA. SEM/EDS data of particles are not suitable to determine $\mathrm{Fe}^{2+} / \mathrm{Fe}^{3+}$ or total halogen content, which is necessary to precisely classify amphiboles. In addition, calculations used to assign element concentrations assume that the material analyzed has a flat, polished surface that is homogeneous in the analysis volume (typically about $2 \mu \mathrm{m}$ for the conditions used in this study). Particle size and geometry can therefore introduce analytical uncertainty as high as 20 percent $(2 \sigma)$ concentration in a given analysis.

The particle size distribution of random amphibole soil particles is summarized in figure 10. Amphiboles with greater than 0.5 aluminum cation per formula unit (as determined with EDS) have a slightly greater width and lower aspect ratio at the 50th percentile than amphiboles with less than 0.5 cation aluminum at the 50th percentile. Seventy-three percent of all 


\section{El Dorado Epidote Composition}

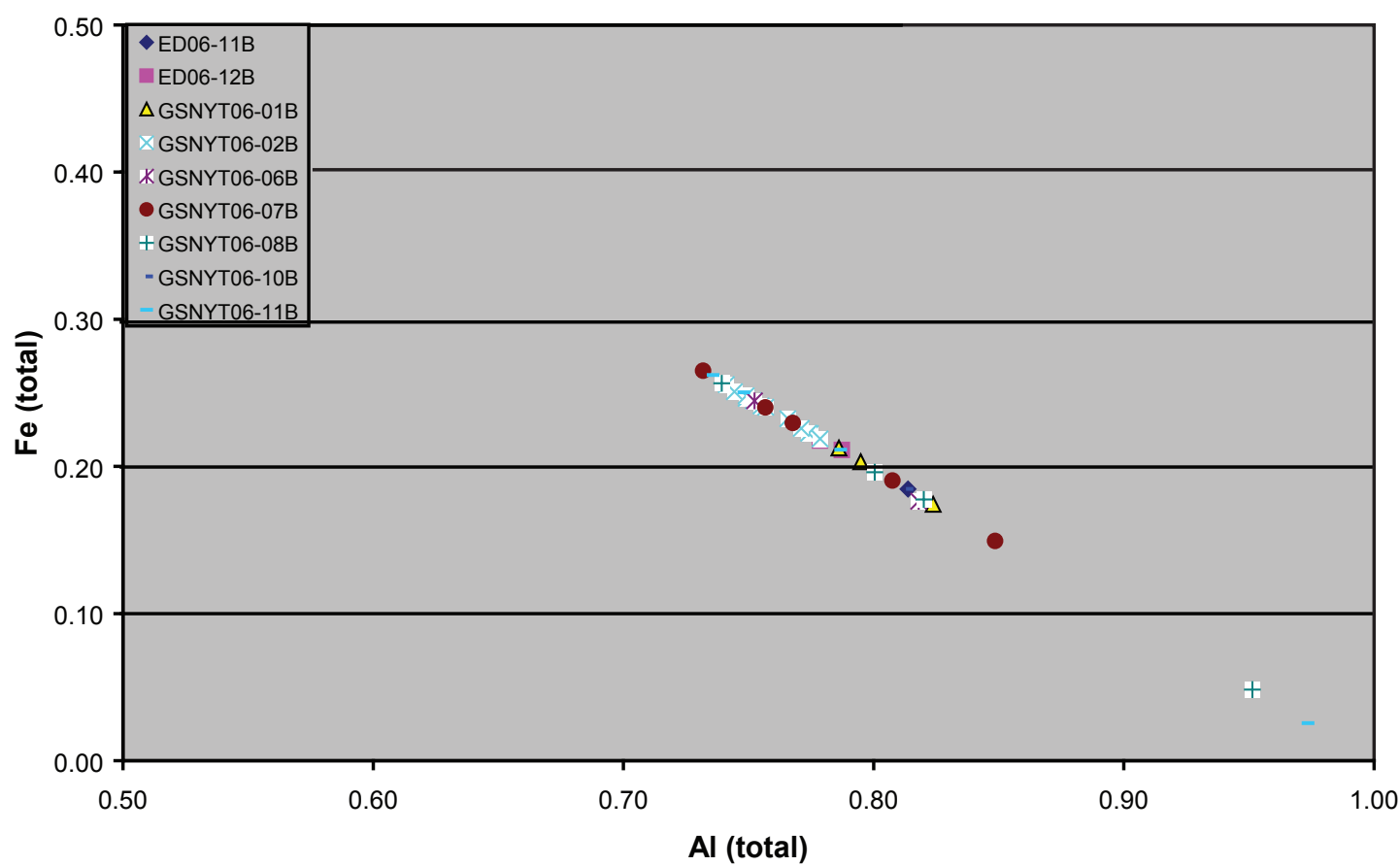

Figure 5. Epidote compositions plotted on aluminum (Al) and iron (Fe) binary diagram. All analyses fall in the clinozoisite compositional field.

EPMA-WDS Analyses of Amphibole in Rocks Collected by USGS from El Dorado Hills $C a_{B}>=1.5 ;(\mathrm{Na}+\mathrm{K})_{A}<0.5 ; \mathrm{Ca}_{\mathrm{A}}<0.5$;

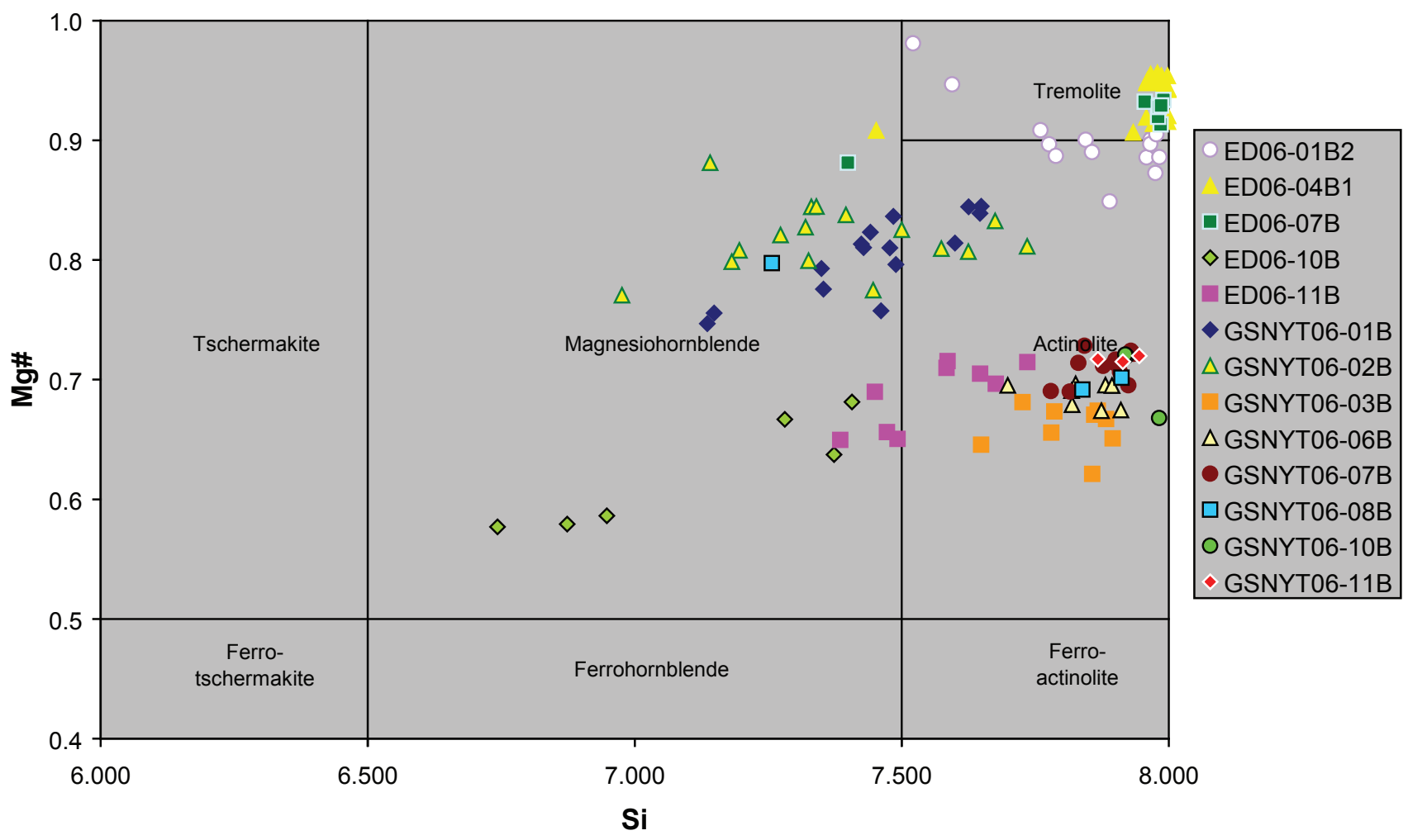

Figure 6. Composition and nomenclature as defined by Leake and others (1997) of El Dorado Hills amphiboles analyzed on polished thin sections of rock samples by EPMA/WDS [Mg\# = Mg/(Mg+Fe $\left.{ }^{2+}\right)$; $\mathrm{Si}$, silicon]. 
Table 5. Representative analyses of amphibole using electron probe microanalysis with wavelength dispersive spectrometry. $\mathrm{ND}=$ not detected.

\begin{tabular}{|c|c|c|c|c|c|}
\hline Sample & GSNYT06-02Ba2pt4 & GSNYT06-01Ba2pt2 & GSNYT06-03Ba1apt5 & GSNYT06-07Ba1pt9 & ED06-01B2a1pt1 \\
\hline Amphibole & actinolite & actinolite & actinolite & actinolite & actinolite \\
\hline $\mathrm{SiO} 2$ & 54.3 & 55.0 & 54.1 & 56.3 & 56.0 \\
\hline $\mathrm{TiO} 2$ & 0.021 & 0.1 & 0.02 & 0.07 & 0.02 \\
\hline $\mathrm{A} 12 \mathrm{O} 3$ & 3.44 & 3.0 & 2.43 & 1.01 & 0.48 \\
\hline $\mathrm{Cr} 2 \mathrm{O} 3$ & 0.007 & 0.4 & ND & ND & 0.04 \\
\hline $\mathrm{FeO}$ & 9.35 & 7.7 & 13.7 & 12.2 & 4.89 \\
\hline $\mathrm{MnO}$ & 0.29 & 0.3 & 0.30 & 0.26 & 0.11 \\
\hline $\mathrm{MgO}$ & 18.1 & 18.9 & 15.2 & 16.7 & 21.2 \\
\hline $\mathrm{CaO}$ & 13.0 & 12.7 & 12.6 & 12.9 & 12.2 \\
\hline $\mathrm{Na} 2 \mathrm{O}$ & 0.43 & 0.5 & 0.21 & 0.11 & 0.05 \\
\hline $\mathrm{K} 2 \mathrm{O}$ & 0.10 & 0.1 & 0.09 & 0.03 & 0.01 \\
\hline $\mathrm{F}$ & ND & ND & 0.09 & ND & 0.06 \\
\hline $\mathrm{Cl}$ & ND & ND & ND & ND & 0.01 \\
\hline $\mathrm{O}=\mathrm{F}, \mathrm{Cl}$ & 0.002 & 0.0 & 0.04 & 0.00 & 0.03 \\
\hline TOTAL & 99.1 & 98.7 & 98.7 & 99.6 & 95.0 \\
\hline $\mathrm{Si}$ & 7.574 & 7.646 & 7.726 & 7.899 & 7.958 \\
\hline $\mathrm{Al}$ iv & 0.426 & 0.354 & 0.274 & 0.101 & 0.042 \\
\hline Sum $T$ & 8.000 & 8.000 & 8.000 & 8.000 & 8.000 \\
\hline $\mathrm{Al}$ vi & 0.139 & 0.137 & 0.135 & 0.067 & 0.038 \\
\hline $\mathrm{Ti}$ & 0.002 & 0.009 & 0.002 & 0.007 & 0.002 \\
\hline $\mathrm{Fe} 3+$ & 0.206 & 0.143 & 0.119 & 0.026 & 0.003 \\
\hline $\mathrm{Cr}$ & 0.001 & 0.046 & 0.000 & 0.000 & 0.004 \\
\hline $\mathrm{Mg}$ & 3.758 & 3.919 & 3.234 & 3.502 & 4.483 \\
\hline $\mathrm{Fe} 2+$ & 0.885 & 0.746 & 1.511 & 1.398 & 0.469 \\
\hline $\mathrm{Mn}$ & 0.009 & 0.000 & 0.000 & 0.000 & 0.000 \\
\hline Sum C & 5.000 & 5.000 & 5.000 & 5.000 & 5.000 \\
\hline $\mathrm{Mg}$ & 0.000 & 0.000 & 0.000 & 0.000 & 0.000 \\
\hline $\mathrm{Fe} 2+$ & 0.000 & 0.006 & 0.003 & 0.005 & 0.109 \\
\hline Mn & 0.025 & 0.035 & 0.037 & 0.030 & 0.013 \\
\hline $\mathrm{Ca}$ & 1.946 & 1.890 & 1.932 & 1.944 & 1.865 \\
\hline $\mathrm{Na}$ & 0.029 & 0.069 & 0.029 & 0.020 & 0.013 \\
\hline Sum B & 2.000 & 2.000 & 2.000 & 2.000 & 2.000 \\
\hline $\mathrm{Na}$ & 0.086 & 0.064 & 0.029 & 0.008 & 0.001 \\
\hline K & 0.018 & 0.014 & 0.016 & 0.006 & 0.003 \\
\hline Sum A & 0.104 & 0.079 & 0.045 & 0.014 & 0.004 \\
\hline Total cation & 15.104 & 15.079 & 15.045 & 15.014 & 15.004 \\
\hline
\end{tabular}


Table 5. Representative analyses of amphibole using electron probe microanalysis with wavelength dispersive spectrometry. ND = not detected.-Continued

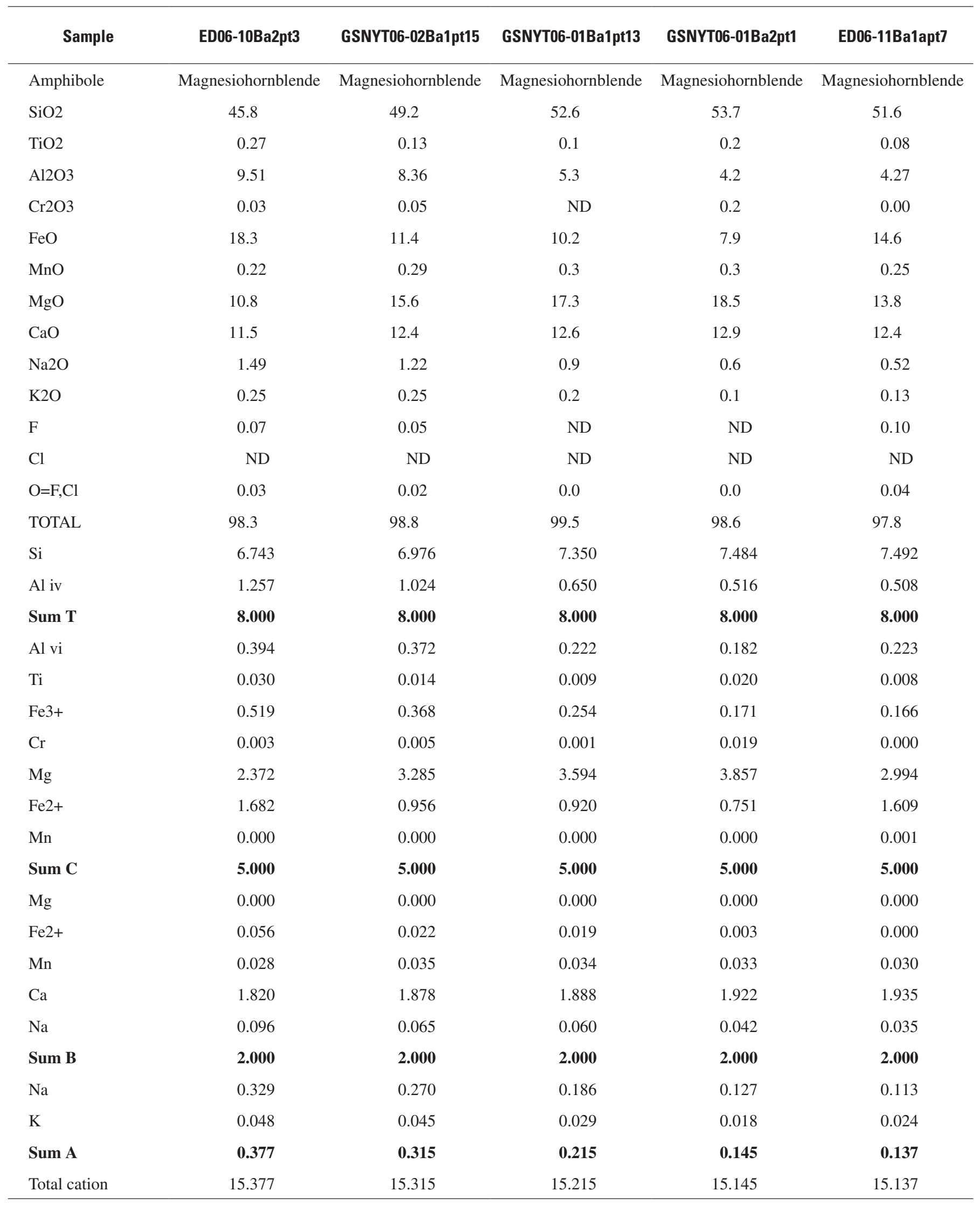


Table 5. Representative analyses of amphibole using electron probe microanalysis with wavelength dispersive spectrometry. ND = not detected. - Continued

\begin{tabular}{|c|c|c|c|c|c|}
\hline Sample & ED06-01B2a1pt2 & ED06-01B2a1pt5 & ED06-01B2a1pt22 & ED06-07Ba3pt3 & ED06-07Ba1pt4 \\
\hline Amphibole & tremolite & tremolite & tremolite & tremolite & tremolite \\
\hline $\mathrm{SiO} 2$ & 53.2 & 55.3 & 56.7 & 59.1 & 59.2 \\
\hline $\mathrm{TiO} 2$ & ND & 0.03 & 0.03 & ND & ND \\
\hline $\mathrm{A} 12 \mathrm{O} 3$ & 2.89 & 2.58 & 1.31 & 0.17 & 0.1 \\
\hline $\mathrm{Cr} 2 \mathrm{O} 3$ & 0.11 & 0.14 & 0.11 & 0.15 & 0.1 \\
\hline $\mathrm{FeO}$ & 4.65 & 4.25 & 4.98 & 3.13 & 3.0 \\
\hline $\mathrm{MnO}$ & 0.07 & 0.04 & 0.11 & 0.11 & 0.1 \\
\hline $\mathrm{MgO}$ & 22.7 & 22.2 & 21.9 & 23.0 & 23.2 \\
\hline $\mathrm{CaO}$ & 10.9 & 10.9 & 12.3 & 13.6 & 13.5 \\
\hline $\mathrm{Na} 2 \mathrm{O}$ & 0.06 & 0.02 & 0.04 & 0.06 & 0.1 \\
\hline $\mathrm{K} 2 \mathrm{O}$ & 0.01 & 0.01 & 0.02 & ND & ND \\
\hline $\mathrm{F}$ & ND & 0.17 & 0.04 & ND & ND \\
\hline $\mathrm{Cl}$ & ND & $\mathrm{ND}$ & ND & $\mathrm{ND}$ & ND \\
\hline $\mathrm{O}=\mathrm{F}, \mathrm{Cl}$ & 0.00 & 0.07 & 0.02 & 0.00 & 0.0 \\
\hline TOTAL & 94.5 & 95.6 & 97.4 & 99.3 & 99.2 \\
\hline $\mathrm{Si}$ & 7.521 & 7.760 & 7.844 & 7.986 & 7.990 \\
\hline $\mathrm{Al}$ iv & 0.479 & 0.240 & 0.156 & 0.014 & 0.010 \\
\hline Sum $T$ & 8.000 & 8.000 & 8.000 & 8.000 & 8.000 \\
\hline $\mathrm{Al}$ vi & 0.003 & 0.186 & 0.057 & 0.013 & 0.007 \\
\hline $\mathrm{Ti}$ & 0.000 & 0.004 & 0.003 & 0.000 & 0.000 \\
\hline Fe3+ & 0.457 & 0.030 & 0.077 & 0.001 & 0.007 \\
\hline $\mathrm{Cr}$ & 0.013 & 0.015 & 0.012 & 0.016 & 0.006 \\
\hline $\mathrm{Mg}$ & 4.527 & 4.644 & 4.515 & 4.623 & 4.676 \\
\hline $\mathrm{Fe} 2+$ & 0.000 & 0.121 & 0.336 & 0.348 & 0.303 \\
\hline $\mathrm{Mn}$ & 0.000 & 0.000 & 0.000 & 0.000 & 0.000 \\
\hline Sum C & 5.000 & 5.000 & 5.000 & 5.000 & 5.000 \\
\hline $\mathrm{Mg}$ & 0.248 & 0.000 & 0.000 & 0.000 & 0.000 \\
\hline $\mathrm{Fe} 2+$ & 0.092 & 0.347 & 0.164 & 0.005 & 0.028 \\
\hline Mn & 0.008 & 0.005 & 0.013 & 0.012 & 0.010 \\
\hline $\mathrm{Ca}$ & 1.645 & 1.645 & 1.818 & 1.967 & 1.949 \\
\hline $\mathrm{Na}$ & 0.006 & 0.003 & 0.005 & 0.016 & 0.012 \\
\hline Sum B & 2.000 & 2.000 & 2.000 & 2.000 & 2.000 \\
\hline $\mathrm{Na}$ & 0.009 & 0.003 & 0.005 & 0.000 & 0.002 \\
\hline K & 0.003 & 0.002 & 0.003 & 0.000 & 0.000 \\
\hline Sum A & 0.012 & 0.005 & 0.008 & 0.000 & 0.002 \\
\hline Total cation & 15.012 & 15.005 & 15.008 & 15.000 & 15.002 \\
\hline
\end{tabular}




\section{EPMA-WDS Analysis of an Amphibole from EI Dorado Hills}

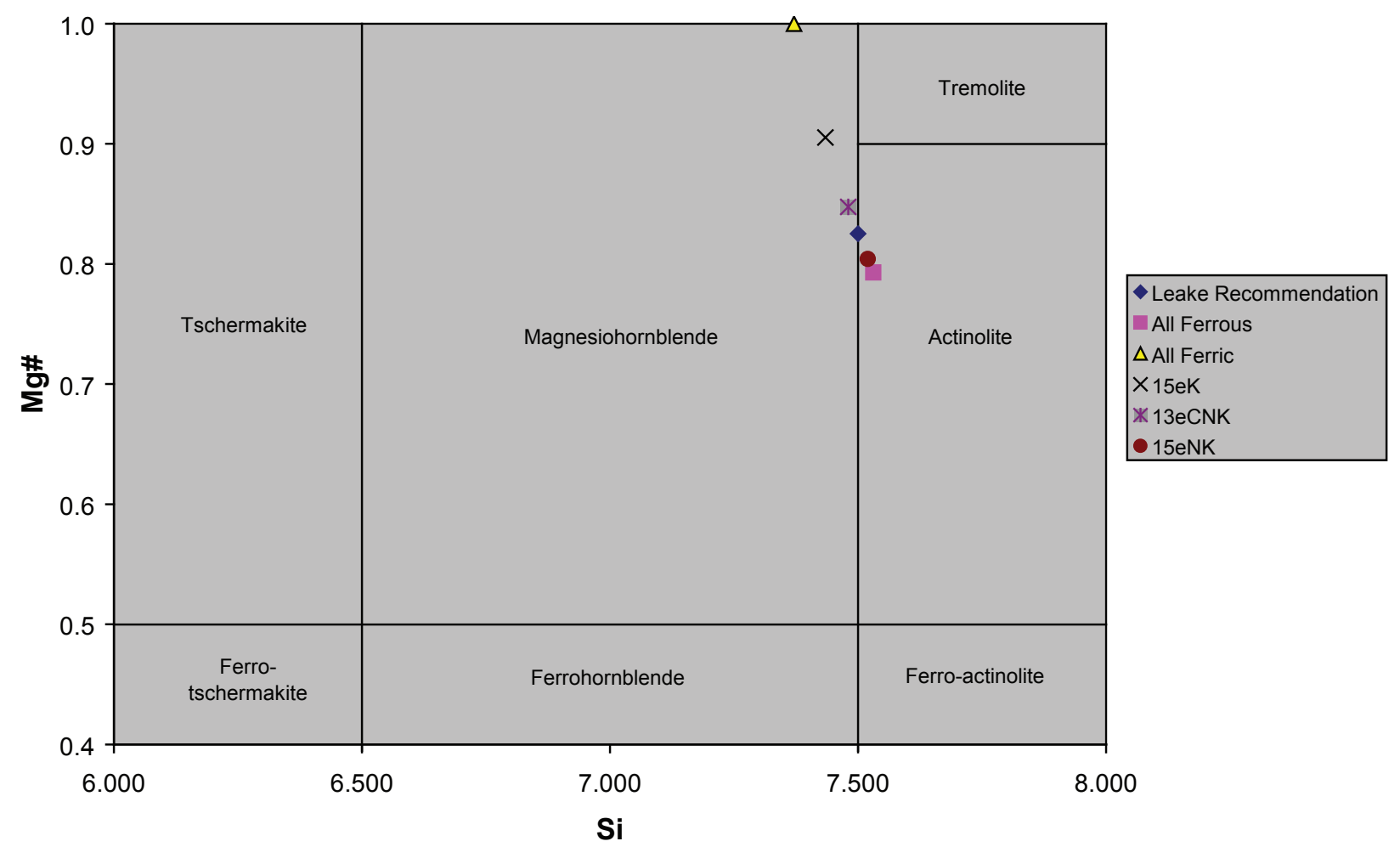

Figure 7. Diagram showing an example of how the classification of the amphibole can change with the method used to determine ferrous/ferric iron ratios. The recommendations of Leake and others (1997) were used determine the ferrous/ ferric iron ratios of the El Dorado Hills amphiboles [Mg\# $=\mathrm{Mg} /\left(\mathrm{Mg}+\mathrm{Fe}^{2+}\right)$; Si, silicon].

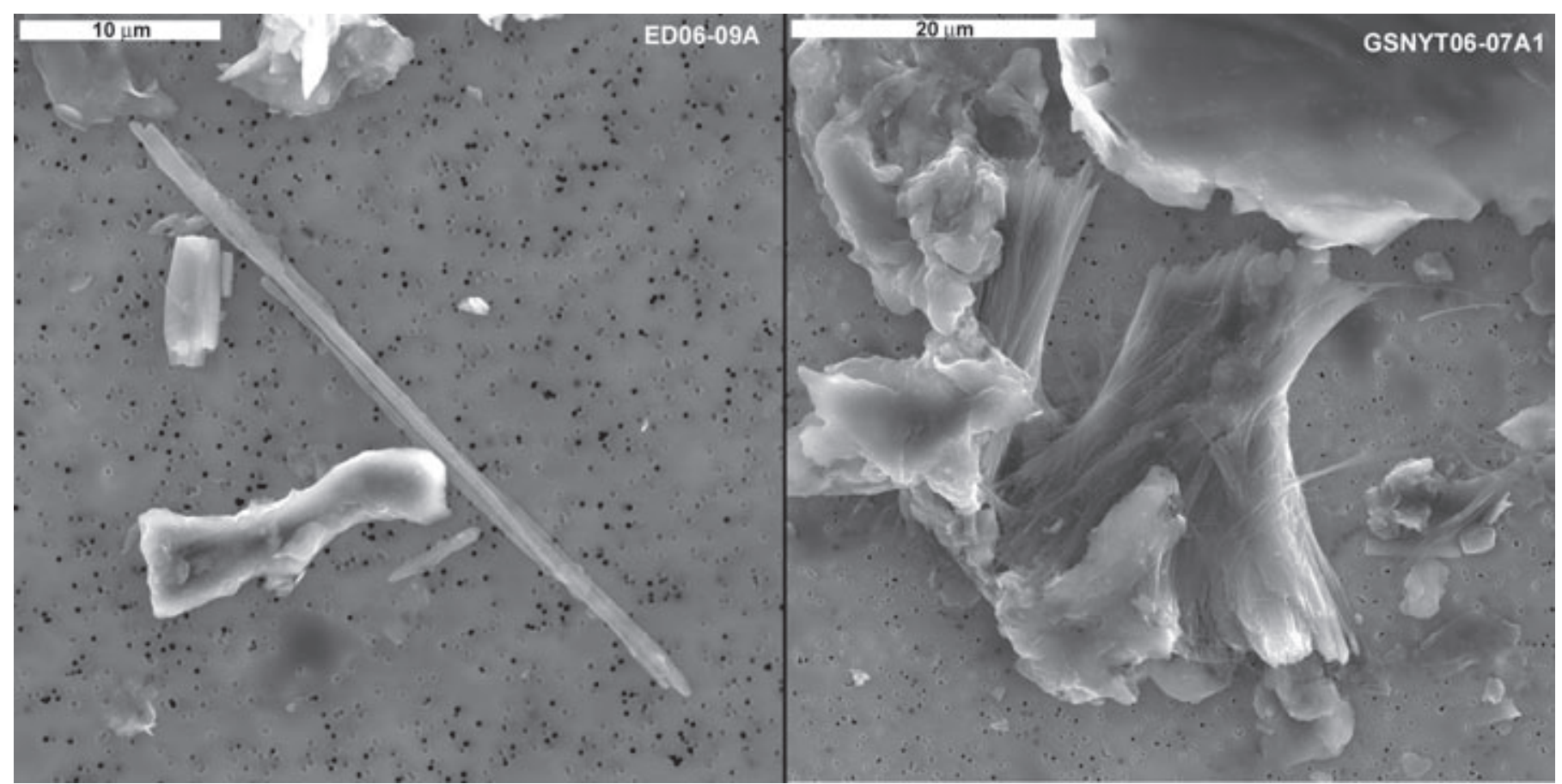

Figure 8. Serpentine (probably chrysotile) structures found in sample ED06-09A (left) and sample GSNYT06-07A1 (right) on the New York Creek Trail. 
SEM-EDS Analyses of Amphiboles in ED06 Soils

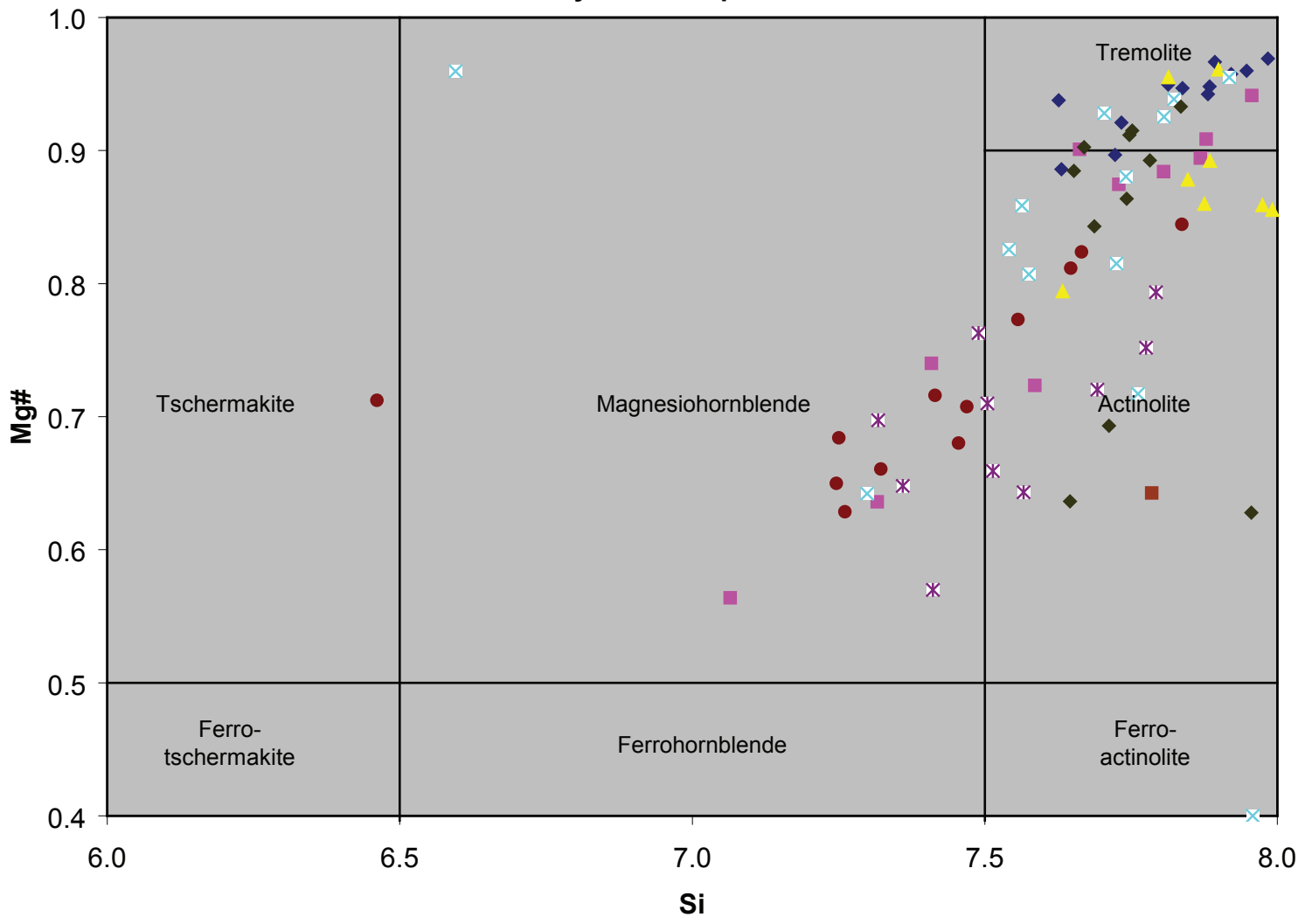

ED06-04A1

ED06-05A1

ED06-07A

ED06-09A

*ED06-10A

- ED06-11A

ED06-ST-5

ED06-ST-6

SEM-EDS Analyses of Amphiboles in New York Creek Trail Soils

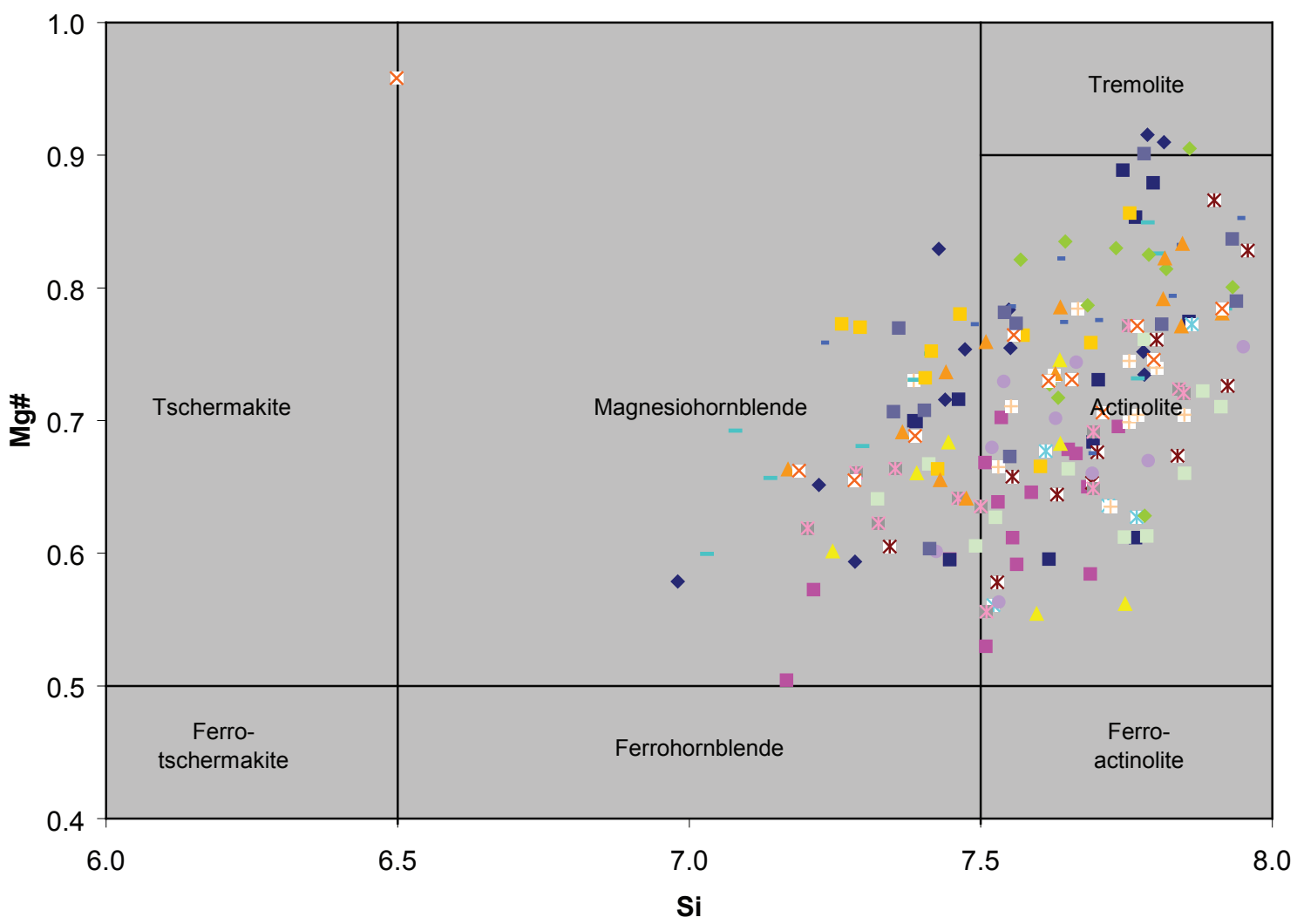

- GSNYT06-01A1

GSNYT06-03A1

GSNYT06-03A2

- GSNYT06-04A1

GSNYT06-05A1

GSNYT06-06A1

* GSNYT06-07A1

GSNYT06-08A1

GSNYT06-09A1

GSNYT06-10A1

- GSNYT06-12A1

GSNYT06-13A1

GSNYT06-14A1

GSNYT06-15A1

GSNYT06-16A1

$\times$ GSNYT06-16A2

GSNYT06-17A1

Figure 9. SEM-EDS analyses of amphiboles from soil samples collected from various locations in the study area in El Dorado Hills, California, and on the New York Creek Trail [Mg\# = Mg/(Mg+Fe $\left.{ }^{2+}\right)$; Si, silicon]. See figure A1 for sample locations. 
amphibole particles examined had mean diameters of $3 \mu \mathrm{m}$ or less. Twenty-eight percent of all amphibole particles examined had aspect ratios greater than 10. Many of the particles displayed striations parallel to the length, stepped sides, and tapered ends; however, some of these features, as observed on individual particles, could be a result of weathering.

The USEPA Study reported amphiboles with widths of 3 $\mu \mathrm{m}$ or less. For this population of particles, our data showed that 95 percent of these particles had lengths greater than $5 \mu \mathrm{m}$ and 95 percent had aspect ratios of 3 or higher. It is these data (fig. 11) that are most appropriate for comparison to the data in The USEPA Study as per their counting rules.

The fiber size distribution of amphibole particles from the south boundary of the recreation center near Harvard Way (ED06-07A) is summarized in figure 12. The average width, length, and aspect ratio of the particles was $0.8 \mu \mathrm{m}, 6 \mu \mathrm{m}$ and 9:1, respectively. These soil particles, shown in figure 13, along with those from soil samples taken at Fairchild Park and rock samples collected on the sidewalk on Woedee Drive, appear to represent a different population of amphiboles than those observed in other samples. The fiber size distribution of these particles can be compared to other amphibole types in figures 10 and 11 . These tremolite-actinolite (tremolitic) particles are generally longer, with higher aspect ratios than the actinolite-magnesiohornblende particles. In addition, these particles often have a fibrous texture locally grading to asbestiform (fig. 14), whereas the amphiboles from the other samples generally have a prismatic to acicular texture (fig. 15).

Portions of activity-based air filter samples collected by USEPA were also examined with SEM by using the same analytical conditions used for the soils. Approximately 10 randomly selected particles were analyzed from each of 8 filter samples. A comparison of size data for these particles is shown in figures 16 and 17, which show a good match between the particles on the USEPA air filters and with the particles found in the soils collected for this study.

The compositions of the amphibole particles on air filters are shown in figure 18. These data are very consistent with compositional data obtained from soils collected from this study. This indicates that the amphiboles analyzed by the USEPA contract laboratories are from the same general populations identified in this study.

\section{Infrared Spectroscopy}

Result of the spectral identifications is given in table 6 . Minerals such as quartz and feldspar lack diagnostic spectral features in the spectral range from 0.35 to $2.5 \mu \mathrm{m}$ so we concentrated identification efforts on $\mathrm{OH}$-bearing mineral phases. Most soil samples in this study are spectrally dominated by epidote and (or) chlorite, kaolinite, Fe-smectite and (or) amphibole. Diagnostic amphibole absorptions, which usually occur near 2.3 $\mu \mathrm{m}$, were frequently obscured by Fe-smectite clay absorptions and in most cases could not be unambiguously identified. The mineralogy of rock samples was less ambiguous due to the near absence of clay absorptions, which allowed identification of epidote, chlorite, mica, and amphibole in many cases, as well as serpentine, talc, or kaolinite in a few cases (table 6). In general, reflectance spectroscopy of raw soil samples cannot be used to reliably to assess the concentration of amphibole or distinguish between amphibole species, due to potential interference from Fe-smectite at the relatively low amphibole concentrations present in these soil samples. Future attempts at spectroscopic identification may achieve better results after removing clays if possible, while not also removing potential fibers.

\section{Summary of Key Analytical Results}

The objective of this study was to characterize and define the chemistry and morphology of amphiboles, primarily those meeting the counting criteria used by USEPA and its contract laboratories, as discussed in The USEPA Study and The RJLG Review. A second goal was, if possible, to identify source areas and depositional mechanisms for the minerals in question and by extension identify any potential problem sites within the study area.

On the basis of chemistry and mineralogy, the mineral particles identified within the study are relatively consistent from sample to sample and include three amphibole mineral types: actinolite, magnesiohornblende, and tremolite (as defined by Leake and others [1997]). Tremolite is locally abundant in the study area and usually occurs in a more fibrous morphology that locally grades to asbestiform. This morphology is demonstrated by fibrous textures seen in many larger particles (figs. 13 and 14) and also by smaller width and higher aspect ratio particles (figs. 11 and 12) than seen in the other amphiboles. Fibrous tremolite was identified in rock and soil samples ED06-07, ED06-07, ED06-04, ED06-05, and ED06-01. Similar material was observed in samples collected by Churchill (CGS) along the road cut on the south side of Harvard Way and in outcrops at the crest of Oak Ridge. All of these locations occur within, or immediately adjacent to, known ultramafic rock units.

Actinolite and magnesiohornblende are the most widely distributed amphibole phases within the study area; the chemistry of these phases is gradational over a considerable compositional range, as shown in figures 6 and 9. Actinolite and magnesiohornblende occur primarily in the mafic metavolcanic and metasedimentary bedrock exposed along the New York Creek Trail and other locations within the study area (fig. 1, fig. A1). The morphologies of these actinolite and magnesiohornblende particles range from fibrous to prismatic. For the most part, the particles analyzed appear to be prismatic crystals rather than cleavage fragments. Prismatic crystals often exhibit primary growth faces whereas cleavage fragments are particles broken off a larger single crystal. It is generally impossible to determine with certainty if a given particle was produced by the process of cleaving. However, the prismatic crystals identified in thin section are compatible in size and shape to those found in soils, which supports the conclusion that the soil particles are mostly single crystals rather than cleavage fragments (fig. 19). Many of the soil particles appear to be highly weathered, as evidenced by cuspate sides and partially dissolved ends (fig. 20). These features suggest that the particles have had relatively longer residence times in the soil. 

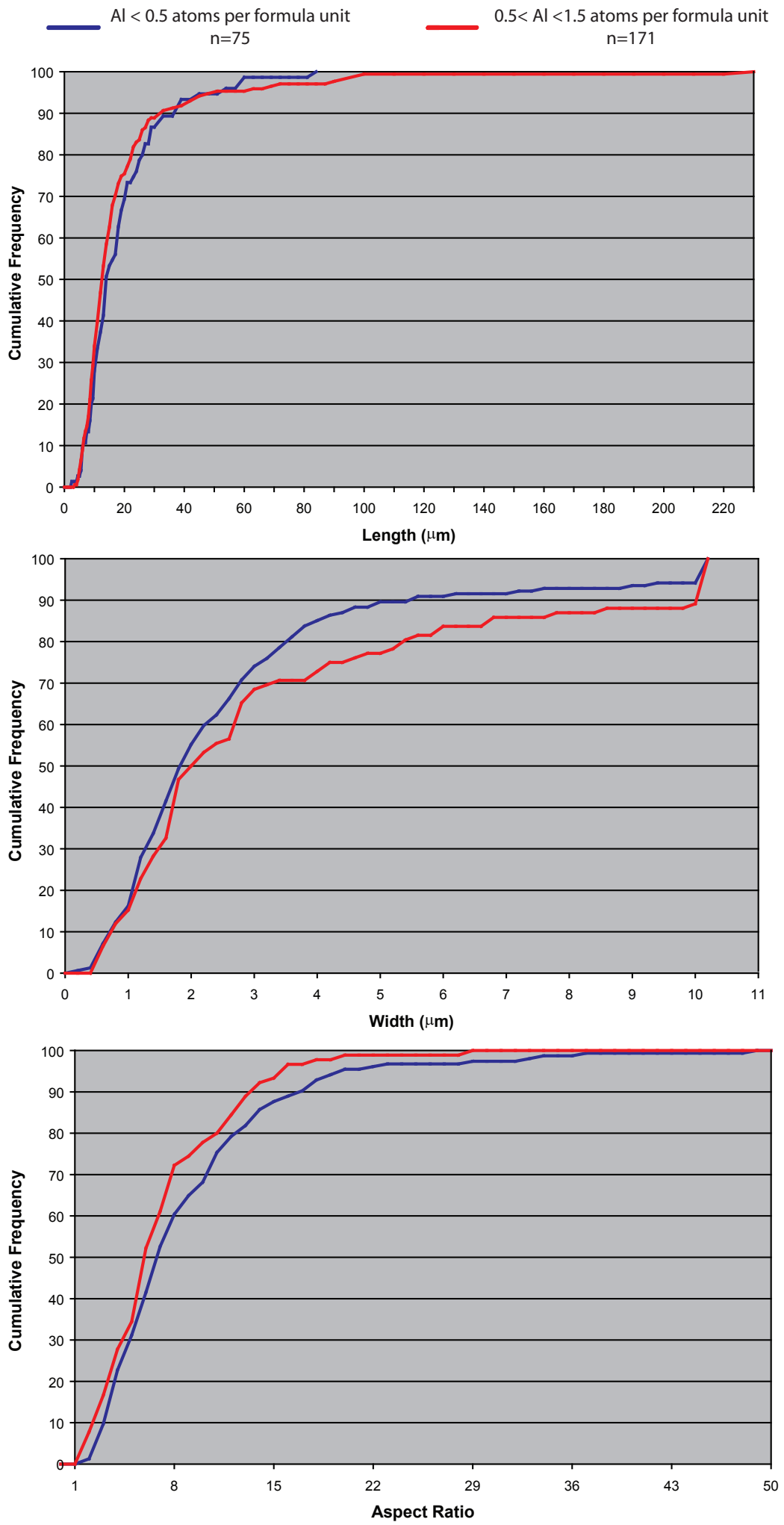

Figure 10. Size distribution of amphibole particles analyzed from soil samples. The plots show the cumulative size distribution of length, width, and aspect ratio for amphibole particles containing less than 0.5 aluminum cation per formula unit (blue) and greater than 0.5 aluminum cation per formula unit (red). The length plot shows, for example, that particles shorter than 10 micrometers $(\mu \mathrm{m})$ make up approximately 15 percent of the population, and 100 percent of the particles are less than $100 \mu \mathrm{m}$ long. 


\section{Mineralogy of Amphiboles Observed in Soils and Rocks in El Dorado Hills, California}

Table 6. Spectroscopy table. [ $\mu \mathrm{m}$, micrometer]

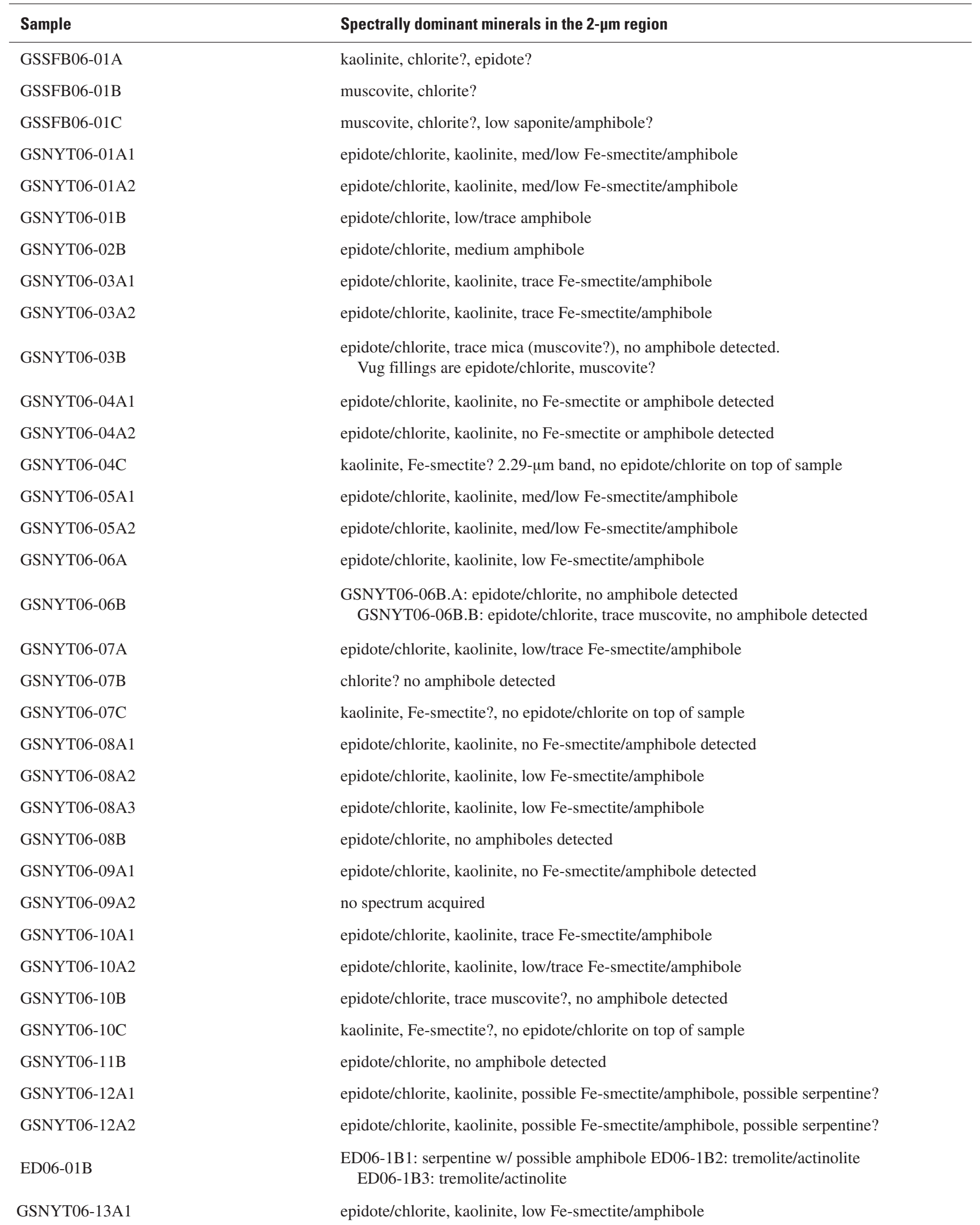


Table 6. Spectroscopy table. [ $\mu \mathrm{m}$, micrometer]-Continued

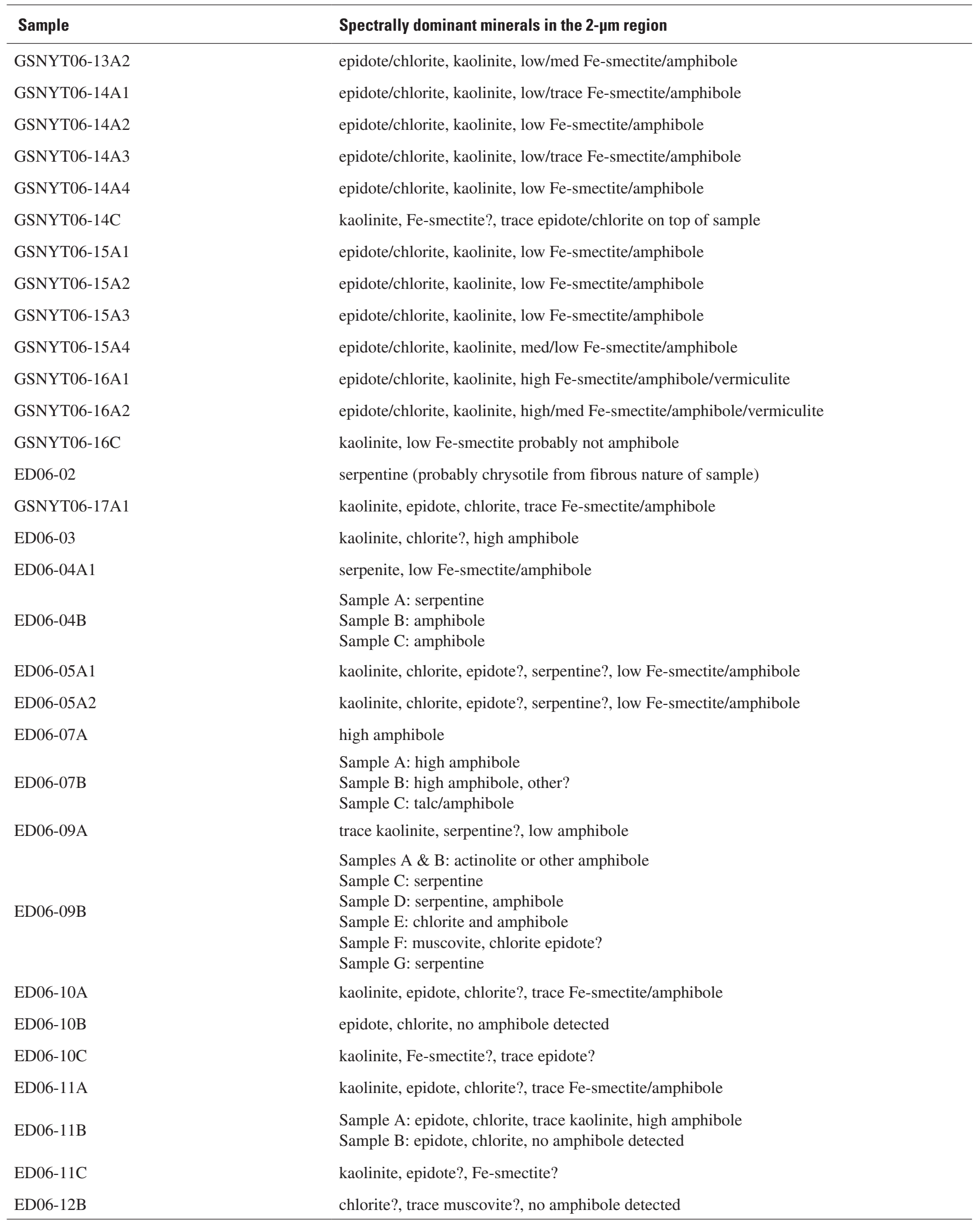



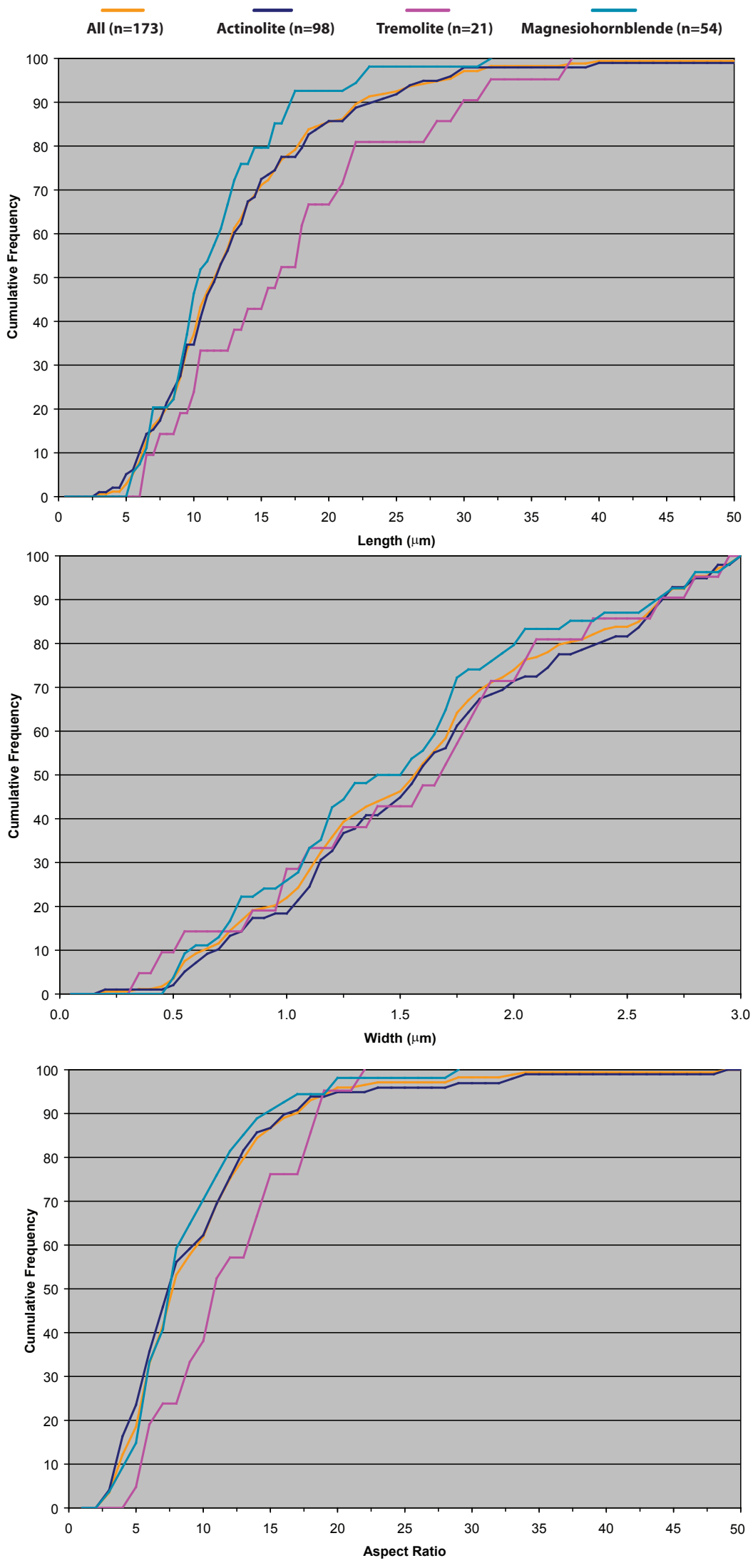

Figure 11. Size distribution of amphibole particles less than or equal to 3 micrometers $(\mu \mathrm{m})$ width. It is particles of these sizes that would have been counted in The USEPA Study. 

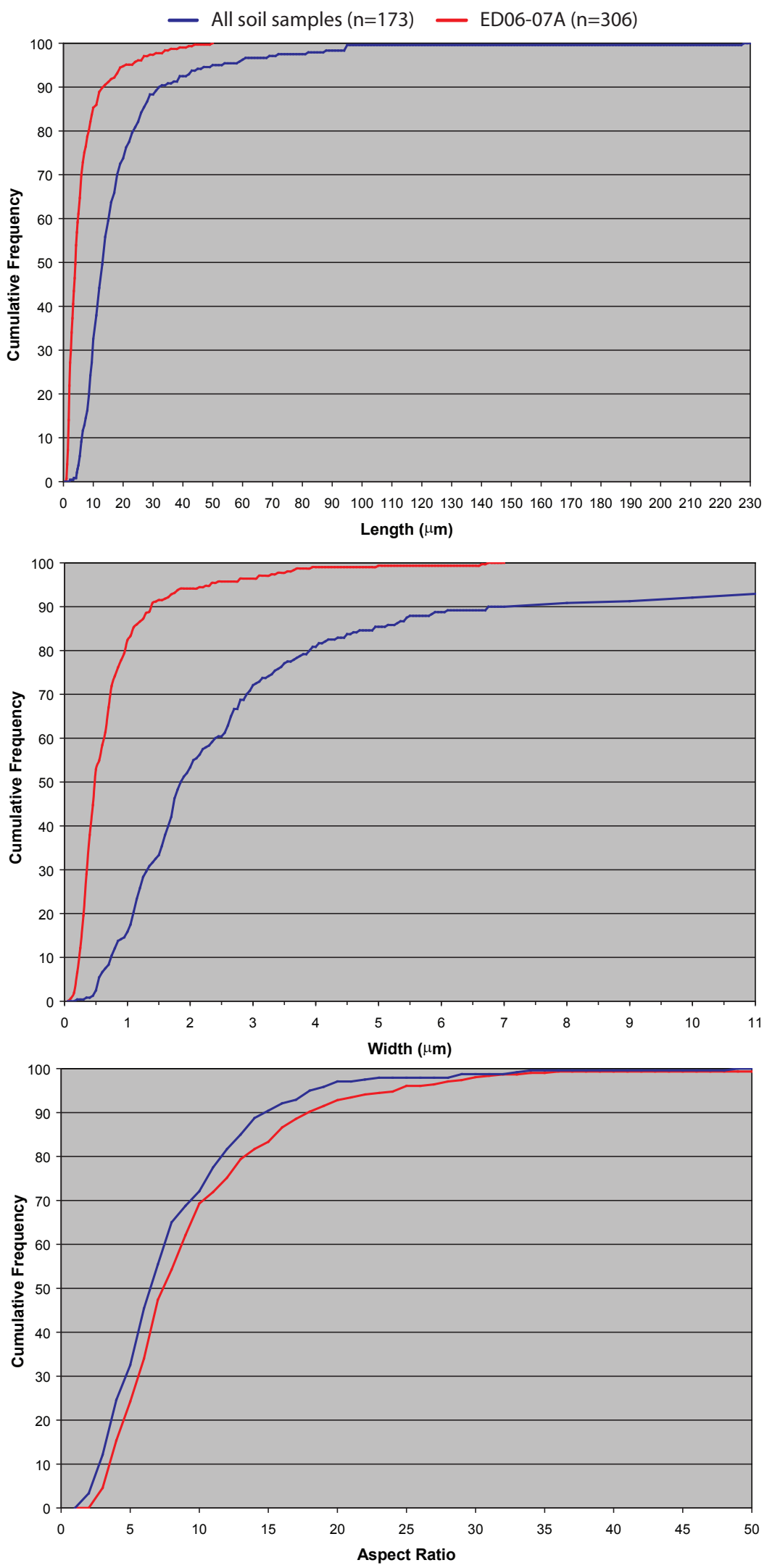

Figure 12. Size distribution of tremolitic particles from soil sample ED06-07A compared to all amphibole particles from all soil samples. Figure 13 shows a typical SEM image field of these particles. 


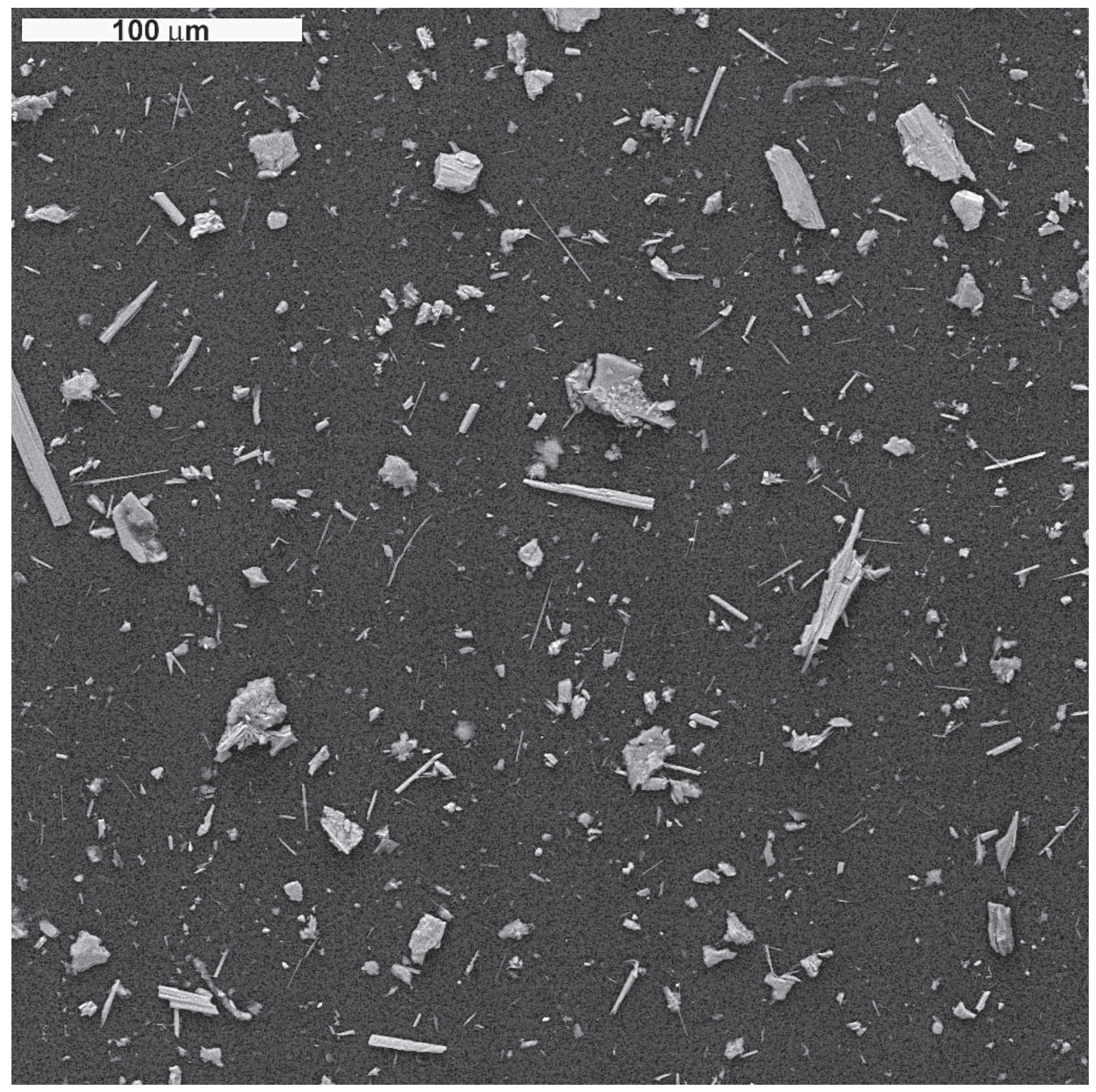

Figure 13. Fibrous tremolite with other particles collected from soil next to the El Dorado Hills recreation center (ED06-07A). 


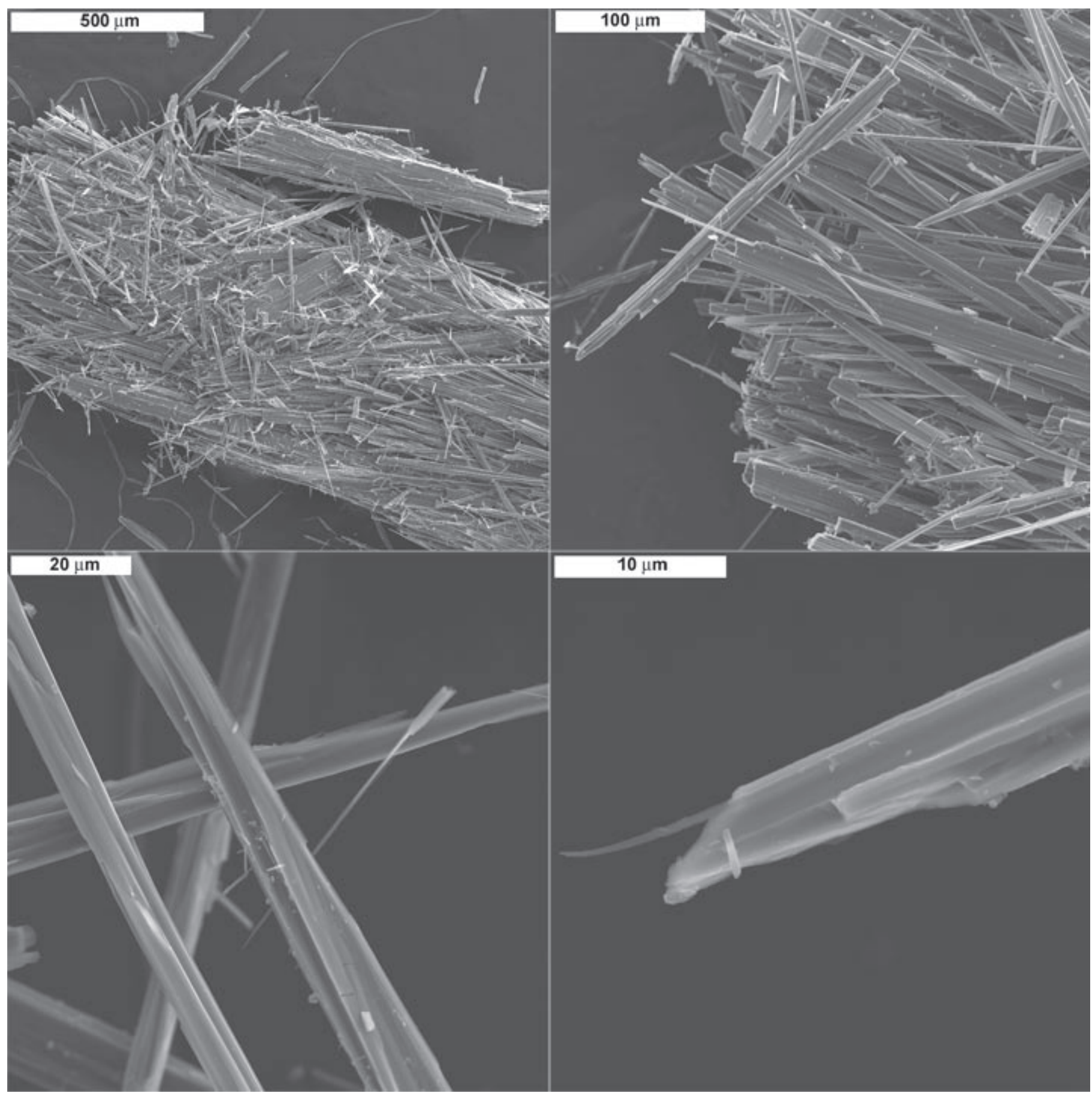

Figure 14. Fibrous to asbestiform tremolite at four different magnifications. Sample collected by Ron Churchill, California Geological Survey, from the south road cut on Harvard Way approximately across the street from the location of the sample shown in figure 13. 

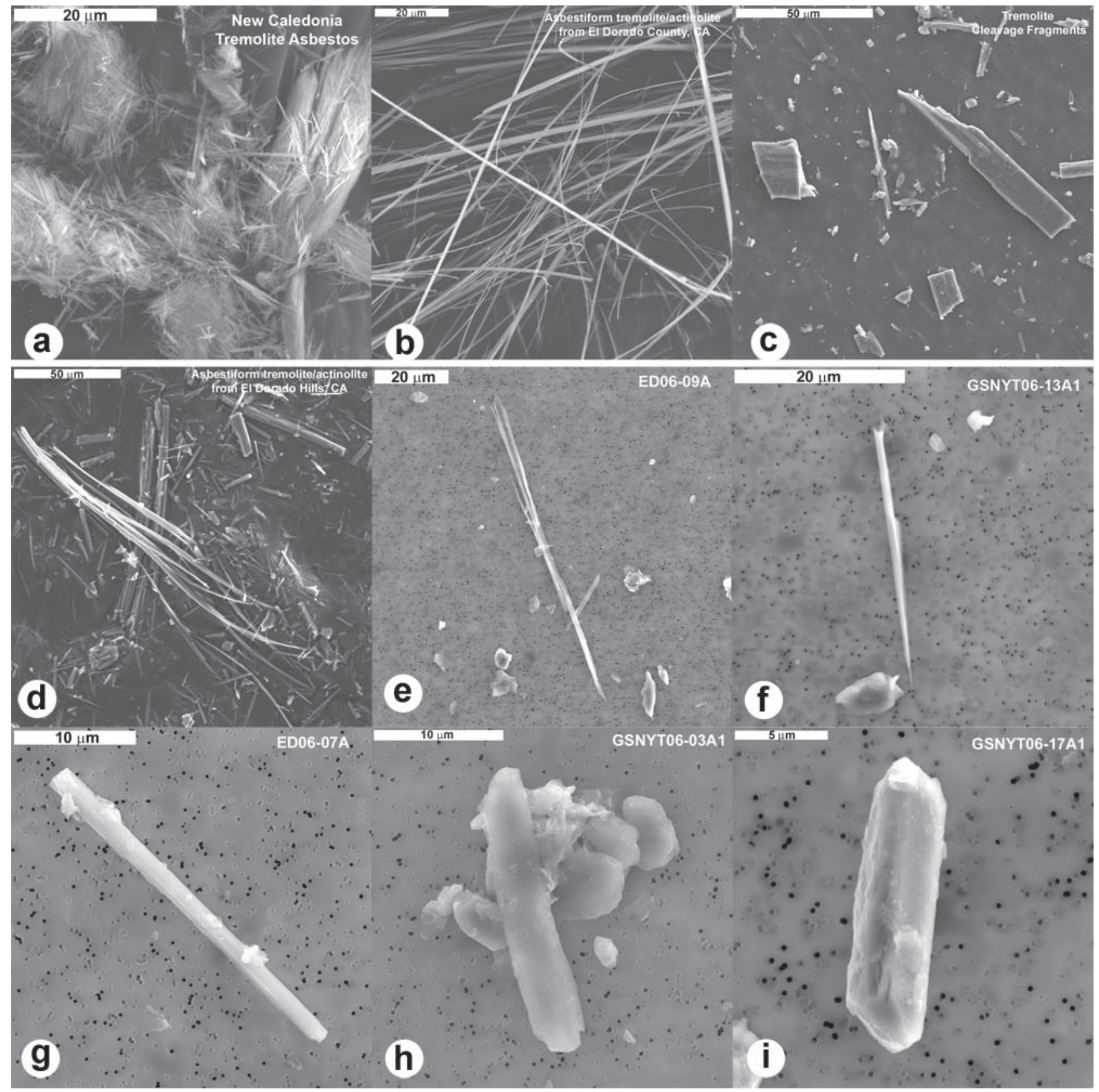

Figure 15. Examples of tremolite morphologies are shown in the top row; (a) asbestiform tremolite from New Caledonia, (b) asbestiform tremolite-actinolite collected approximately $12 \mathrm{~km}$ southeast of Harvard Way, and (c) tremolite cleavage fragments prepared by milling massive tremolite in the laboratory (U.S. Geological Survey sample). The remaining images are examples of amphibole morphologies found in the El Dorado Hills study area samples. These samples range in morphology from asbestiform to fibrous (d-e) and acicular to prismatic ( $f$ - i). Sample location numbers are given in the upper right corner of the El Dorado images. The sample shown in image (d) is from the Harvard Way road cut, collected by Ron Churchill, California Geological Survey. Note differences in scale bars. $\mu \mathrm{m}$, micrometer. 

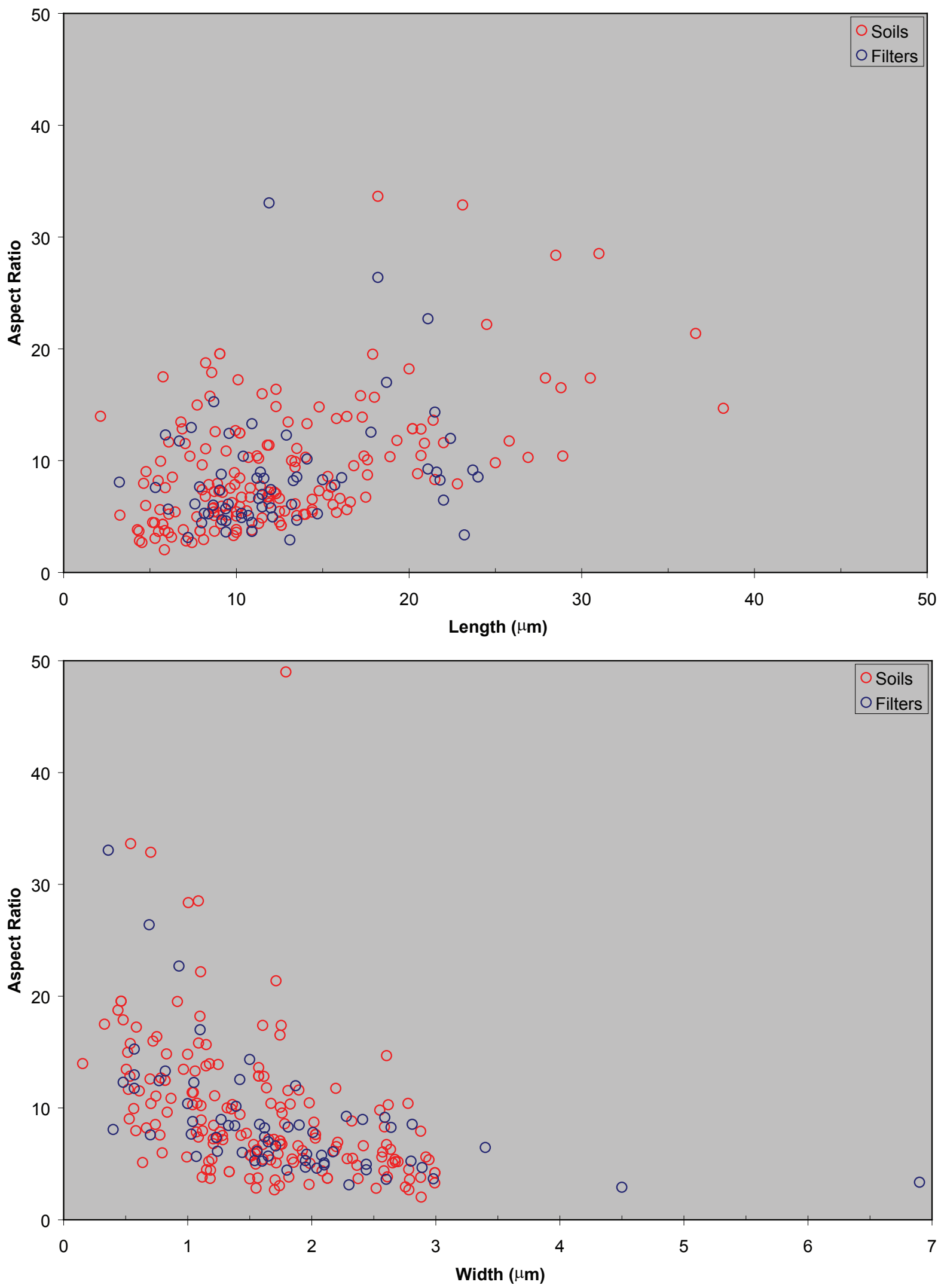

Figure 16. Comparison of amphibole size data from soils collected by the U.S. Geological Survey and air filters collected by the U.S. Environmental Protection Agency. The plots demonstrate that particles of similar size and aspect ratio were counted in both studies. 


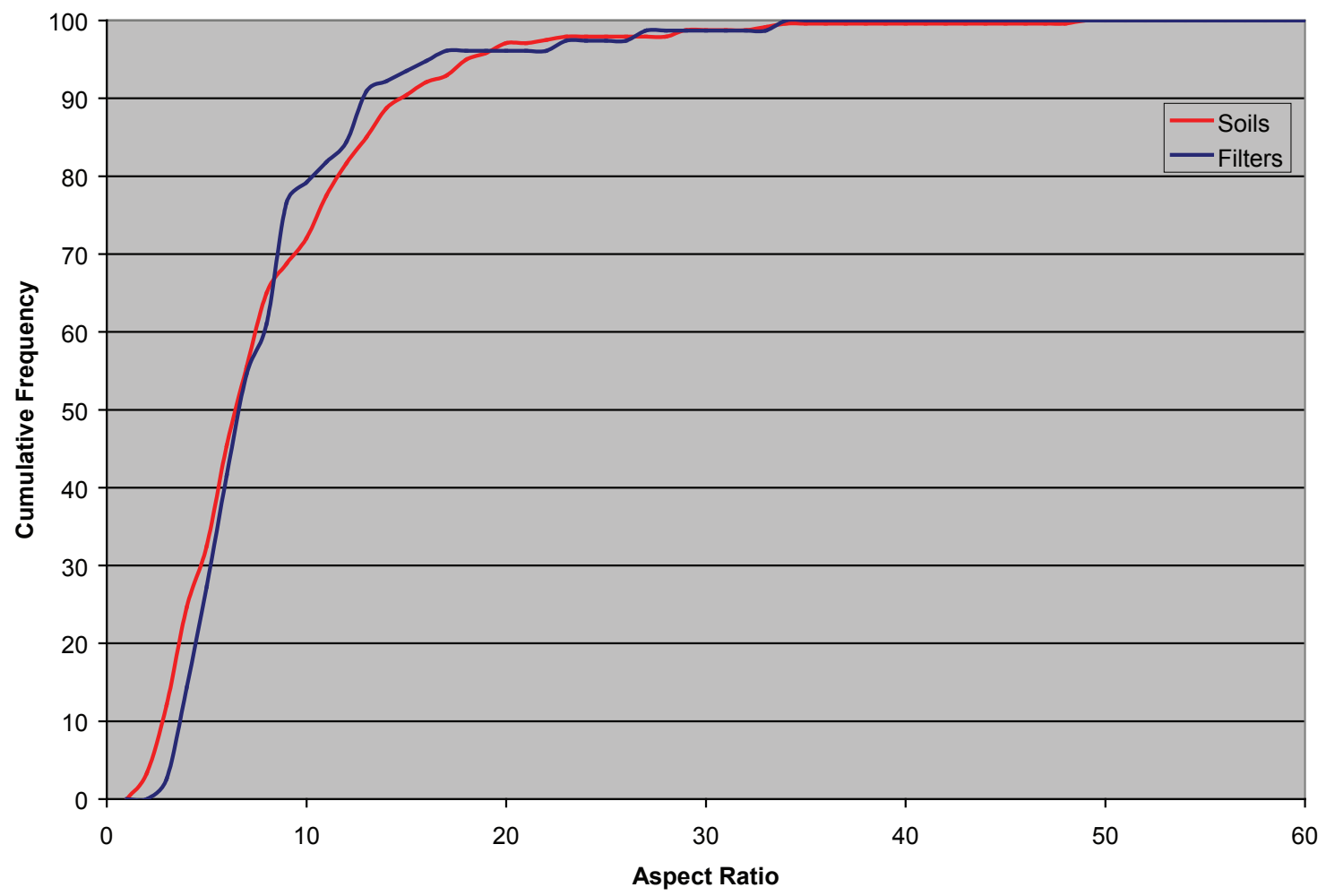

Figure 17. Comparison of amphibole aspect ratios from soils collected by the U.S. Geological Survey and air filters collected by the U.S. Environmental Protection Agency. The plot demonstrates that similar size particles were counted in both studies.

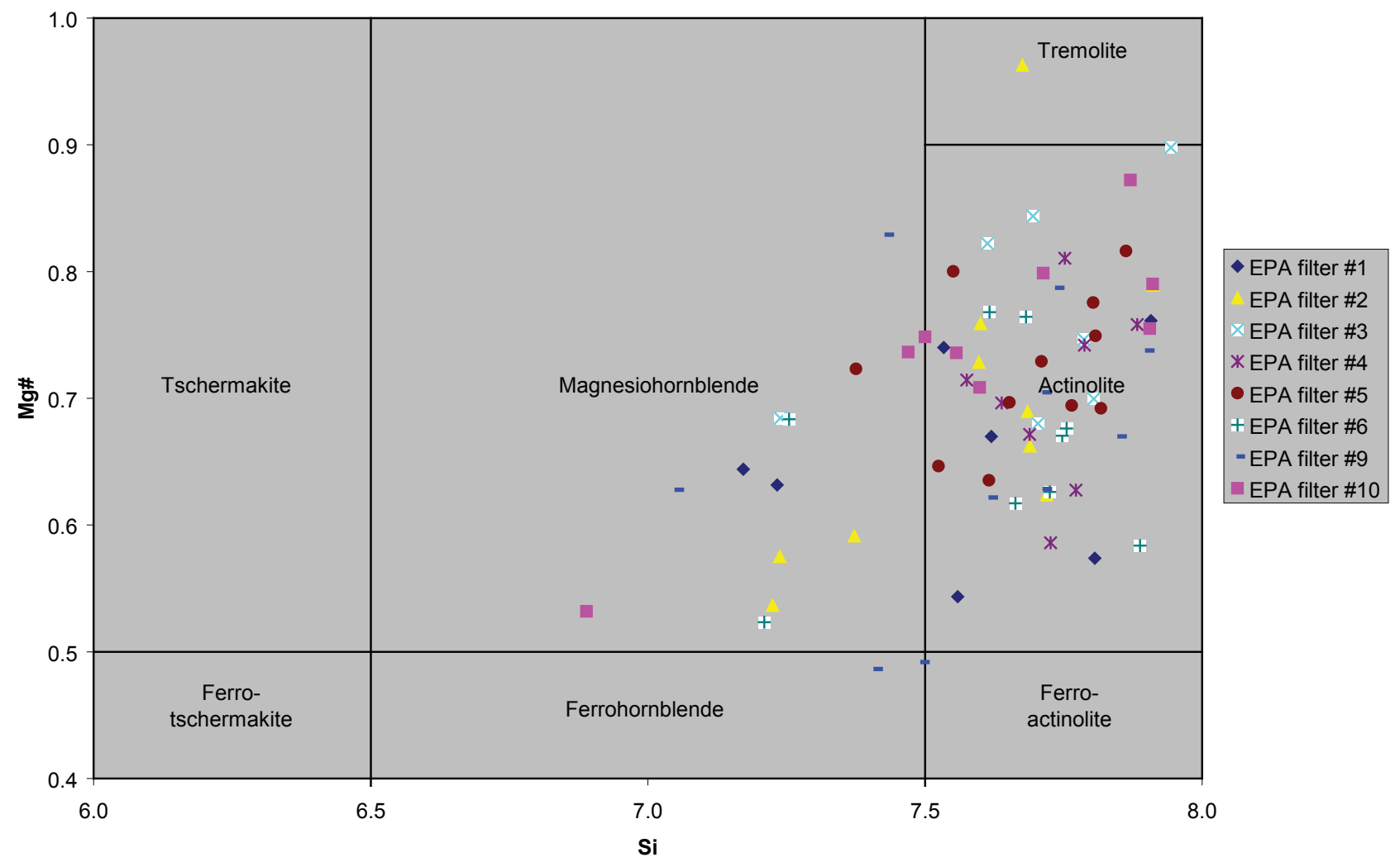

Figure 18. SEM-EDS cation proportions of amphibole particles from air filters collected by the U.S. Environmental Protection Agency. The plot demonstrates that particles of similar composition to those shown in figure 9 from the U.S. Geological Survey samples were found on the air filters collected for The USEPA Study [Mg\# = Mg/(Mg+Fe2+); Si, silicon]. 


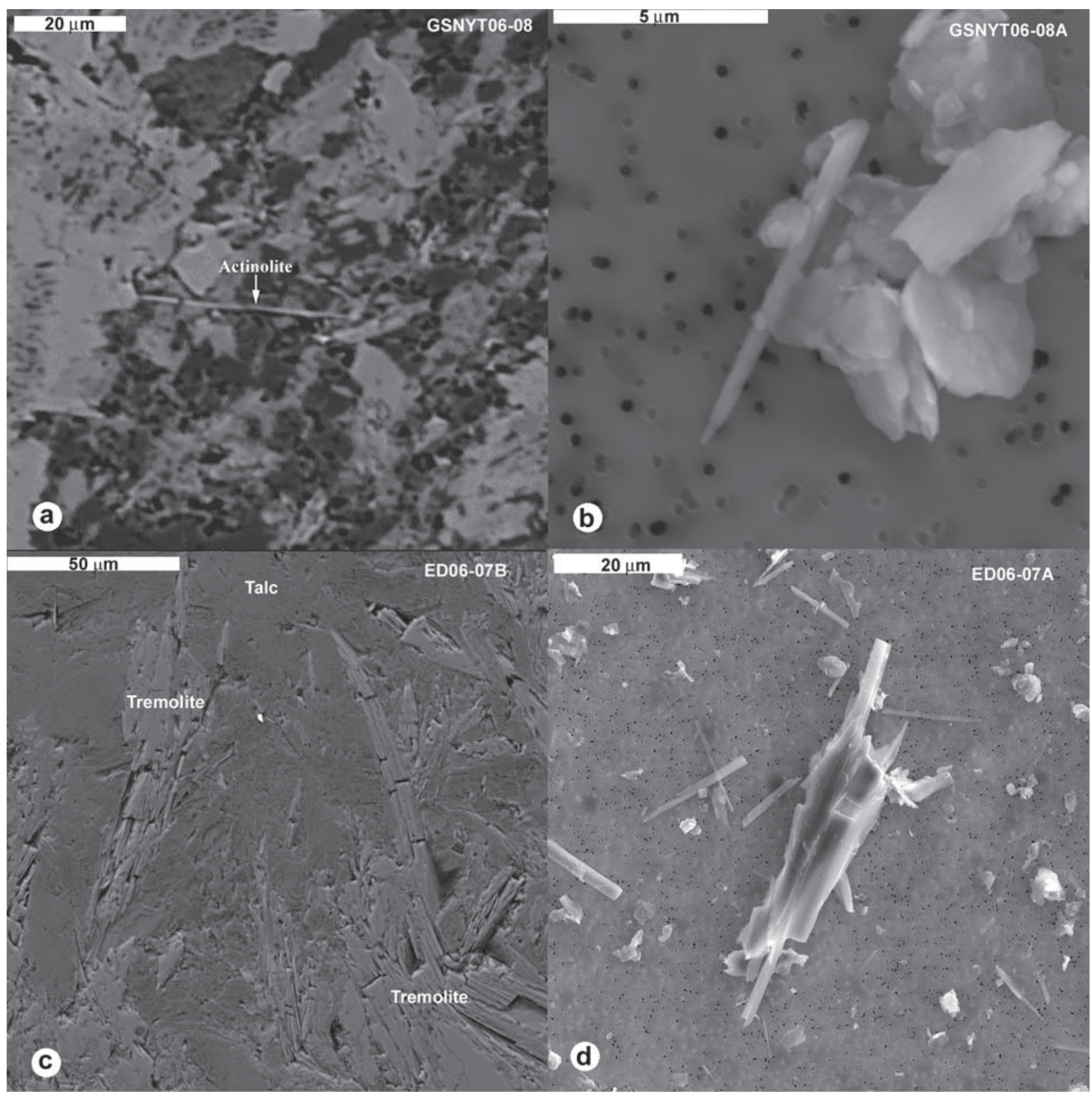

Figure 19. Actinolite (a) and tremolite (c) in rock samples have similar morphology to actinolite (b) and tremolite (d) found in soils. $\mu \mathrm{m}$, micrometer. 


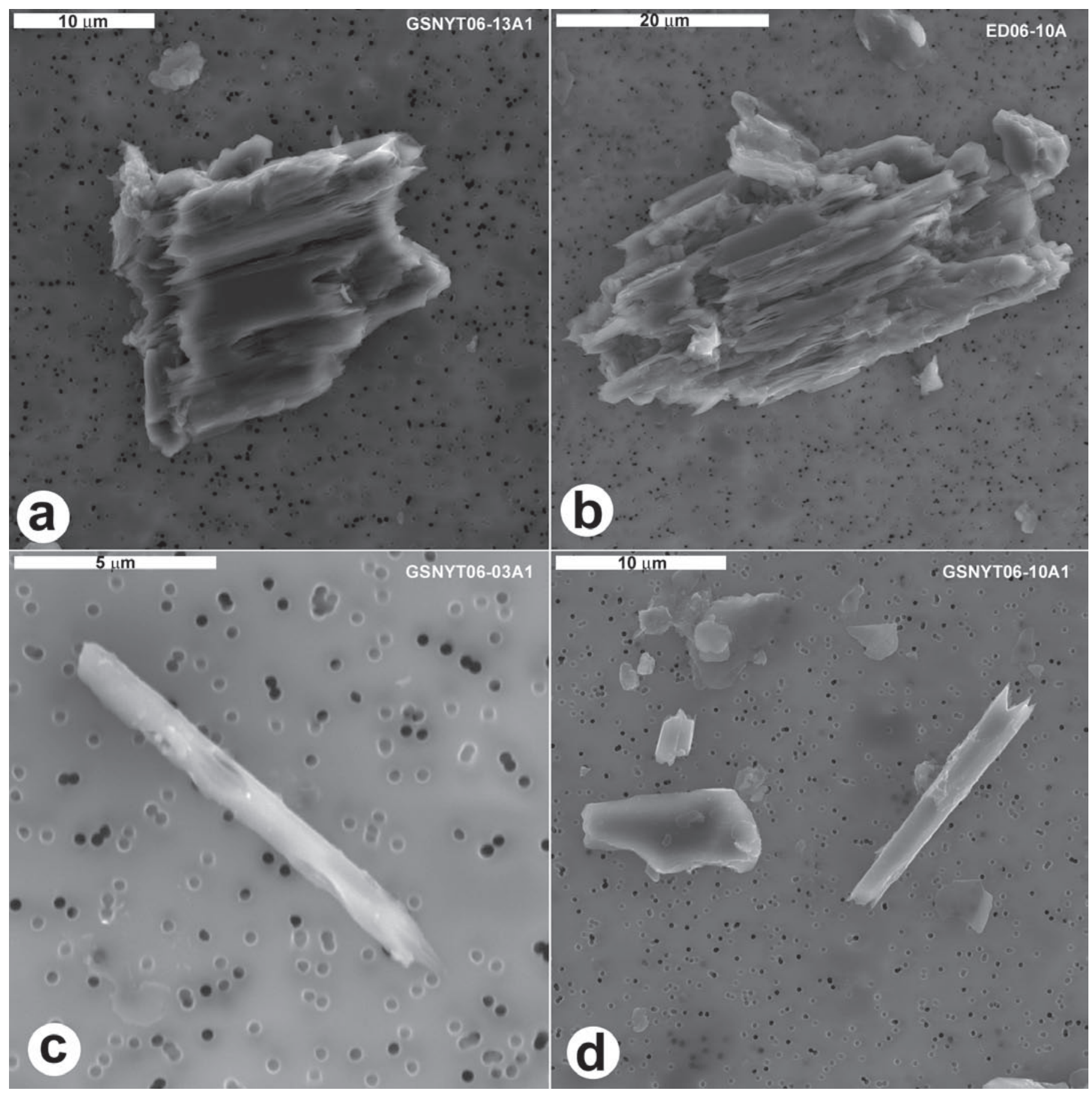

Figure 20. Typical weathering features of (a) magnesiohornblende and actinolite (b, $c$, and d). $\mu$ m, micrometer.

Figure 21 shows mineral compositions of soil-rock pairs by location. These data suggest that, for the most part, the soils are locally derived by weathering in place rather than transported to the site by water or wind. This finding suggests that any problem areas for potential exposure could be dealt with locally because materials of potential concern are not being transported into the study area. The apparent local derivation of soils from underlying bedrock, at least for this study area, also may aid in evaluation of potential problem areas for future development. This concept is not new and and was mentioned in Clinkenbeard and others, (2002).

Sample ED06-07, collected just north of Harvard Way and south of the Community Center building, contained a high concentration of fibrous to asbestiform tremoliteactinolite. This material was evident in soil and rock samples. A stub sample (ED06ST-05) was collected from the top of an electrical box on the south side of the Recreation Center building (fig. 22). The box was shielded from rain 

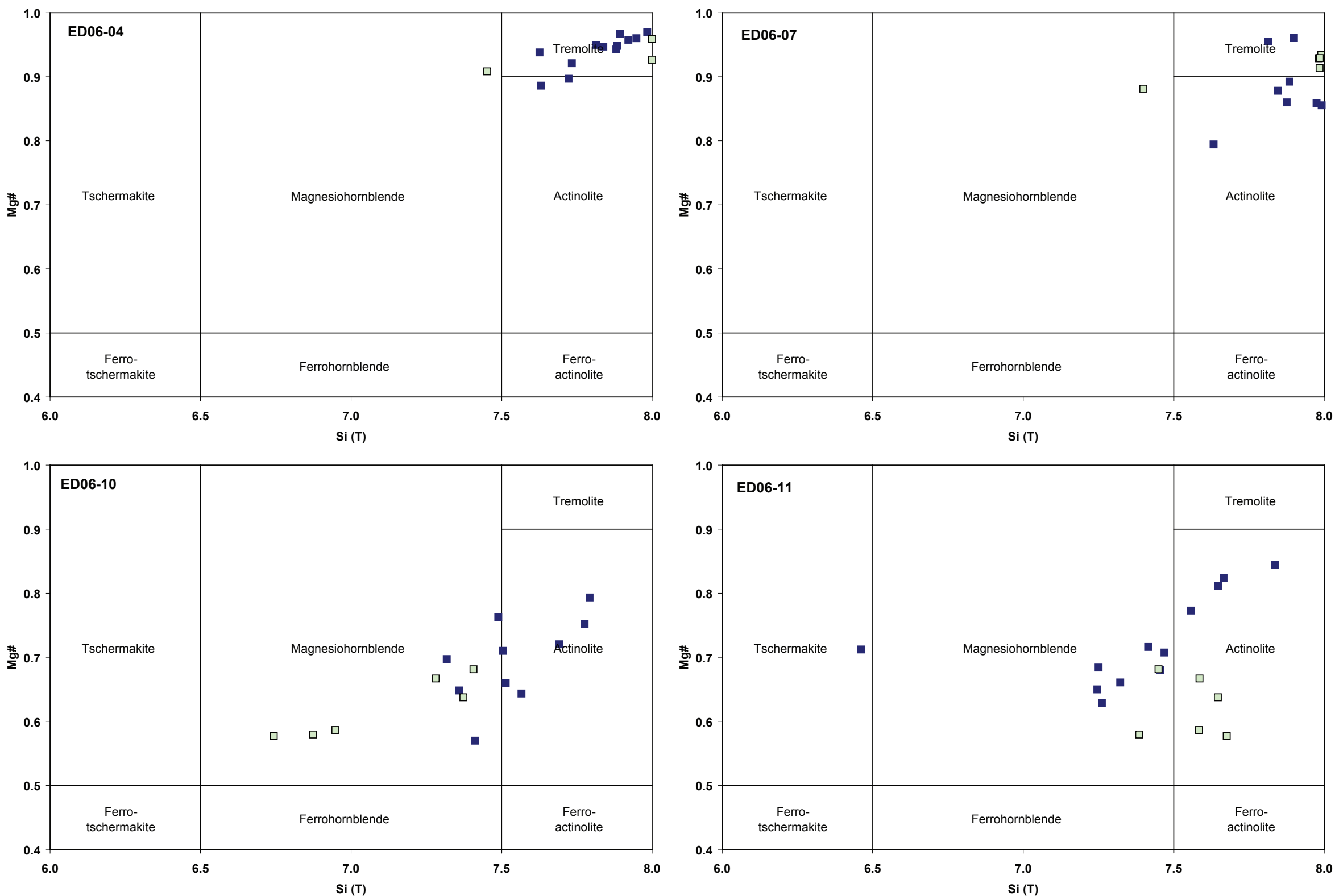

Figure 21. Comparison of EPMA/WDS analyses of amphibole in rock samples (green) to SEM/EDS analyses of amphiboles in soils (blue). The plot demonstrates a good correlation of rock and adjacent soil amphibole compositions suggesting that soil particles are locally derived [Mg\# $=\mathrm{Mg} /\left(\mathrm{Mg}+\mathrm{Fe}^{2+}\right)$; Si (T), silicon in the tetrahedral site] 

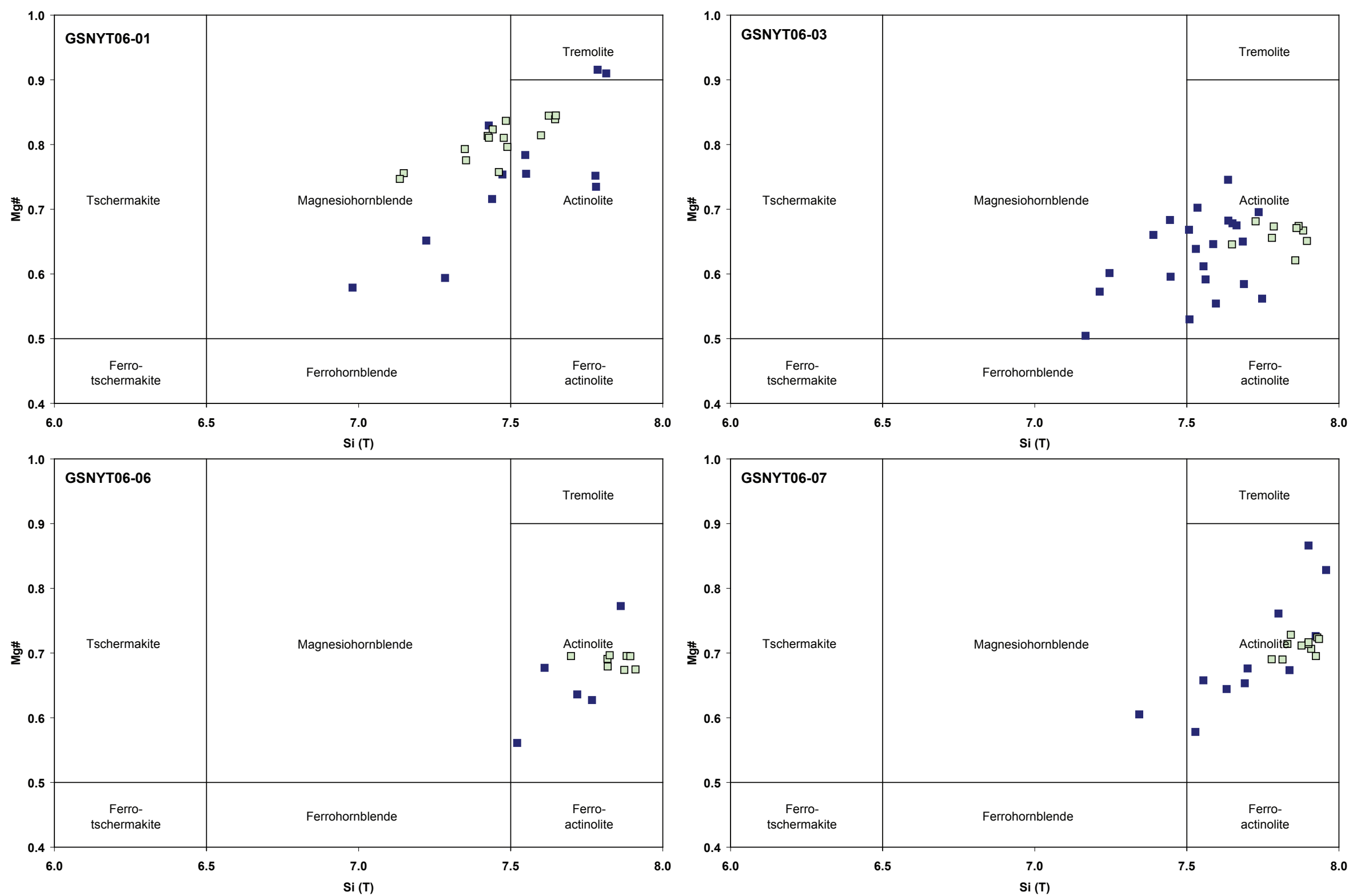

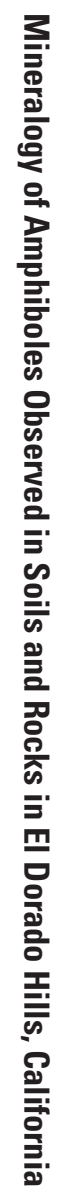

Figure 21—Continued. Comparison of EPMA/WDS analyses of amphibole in rock samples (green) to SEM/EDS analyses of amphiboles in soils (blue). 

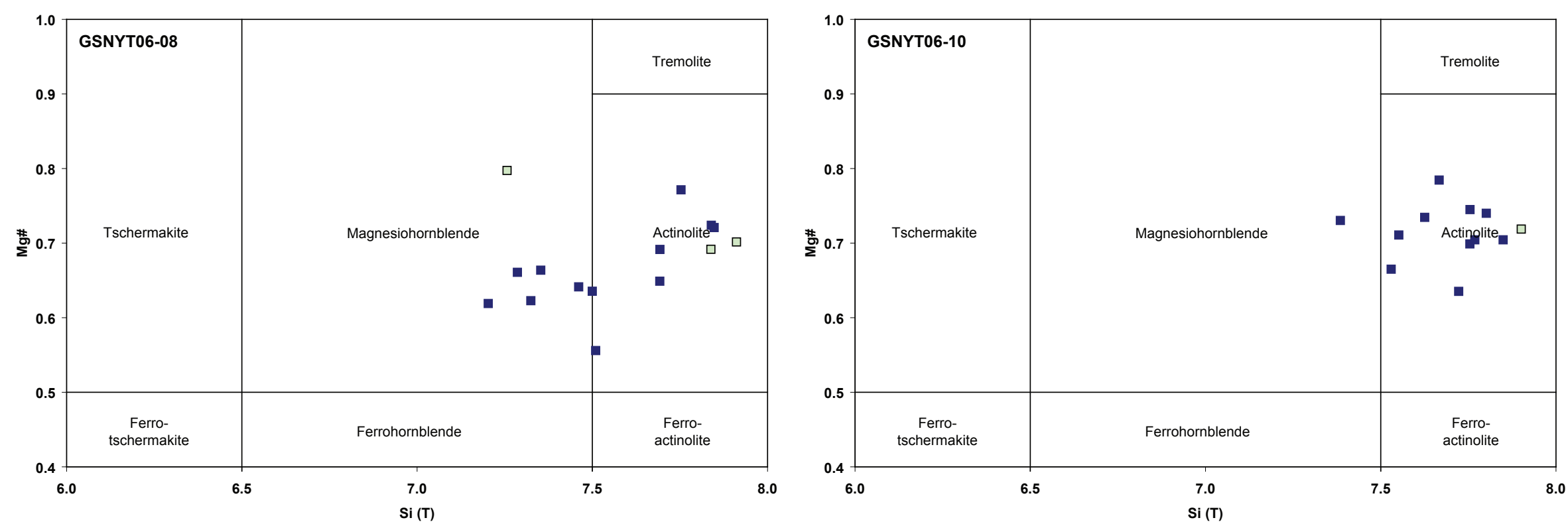

Figure 21—Continued. Comparison of EPMA/WDS analyses of amphibole in rock samples (green) to SEM/EDS analyses of amphiboles in soils (blue). 

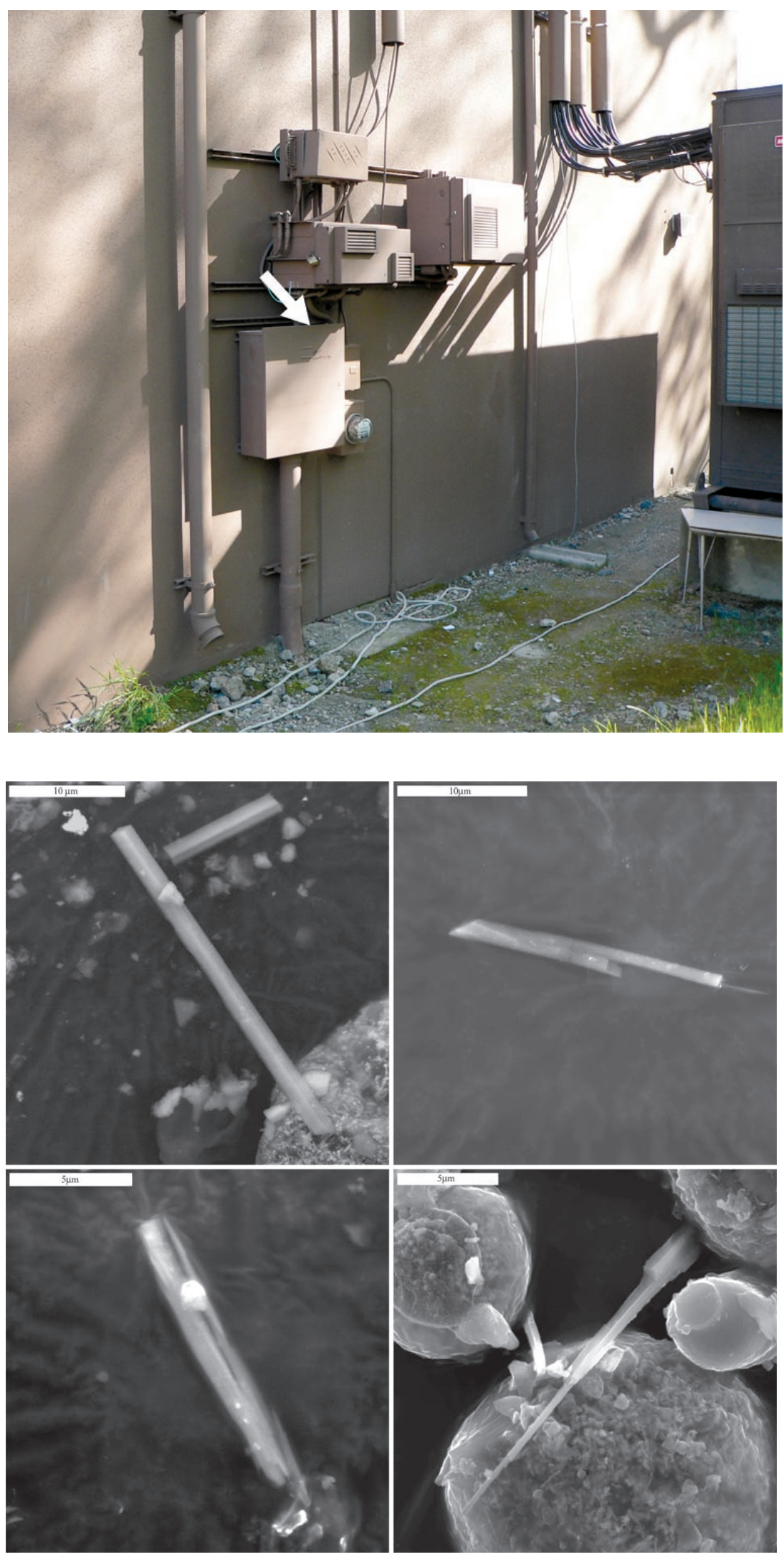

Figure 22. Electrical box sample location from the south wall of the Recreation Center (see arrow for exact sampling location). SEM images of typical amphiboles collected from top surface of the electrical box are shown below. 
and probably represents material deposited over a relatively long time period. The electrical box is located approximately 18 feet from the outcrop/soil samples. This sample contained a significant amount of fibrous tremolite-actinolite, suggesting wind-borne deposition. Other stub samples that were collected at locations farther away from the outcrop did not show similar particles; however, these sample locations were not shielded from the rain and were likely cleaned by several weeks of rain just before sampling for this study.

\section{Discussion}

Central to the issues raised in The USEPA Study and The RJLG Review is the definition of asbestos, and its application to this study area. Asbestos has been defined by workers in many disciplines including those in the commercial asbestos industry and the mining industry, the public health community, those in the regulatory community, and the mineralogical and geological sciences. Many of these definitions are given in a compilation prepared by Lowers and Meeker (2002). It is clear from that compilation that the definition of asbestos (and related terminology) can vary depending on the source and purpose. For example, a definition of asbestos appropriate for the asbestos cloth industry, which might require a very long, thin, highly flexible fiber might be different from that used in the asbestos cement pipe industry which could utilize a more brittle and perhaps shorter and wider fiber. Both of these definitions could be vastly different from those used in the health community, where the concern is exposure, risk, and ultimately disease.

The USEPA Study was conducted to identify potential risk to "asbestos" exposure in certain areas in the El Dorado Hills community. The study employed standard and accepted analytical techniques and definitions, and reported results based on those analyses. Unfortunately, all of the approved, peer reviewed standard methods were developed for analysis of commercial-grade asbestos found in the workplace and in consumer products. That is, the methods were developed to specifically analyze for commercial-grade asbestos in media where there may be reason to expect its presence. In order to be of commercial value, asbestos must be in sufficient quality and purity for the application, and must occur in sufficient abundance to be mined at a profit. In nature, such occurrences are very rare. Far more common is material that can be present in small veins or pods and in quality that can grade from asbestiform to fibrous to acicular to prismatic.

Because the analytical methods utilized by the USEPA contract laboratories were developed specifically for the asbestiform and perhaps fibrous varieties, they do not discriminate or exclude acicular to prismatic particles that otherwise meet the prescribed criteria for identification. Therefore, no standardized criteria exist for laboratories to apply that are not highly subjective and which require significant interpretation by the analyst as to whether a particle is prismatic, fibrous, or asbestiform. Furthermore, making such interpretations places the analyst in the inappropriate position of deciding which particles might pose a health risk and which particles do not. The only "official" guidance available is that of Occupational Safety and Health Administration (OSHA, 1992) for the subjective identification of "asbestiform" fiber and differentiation from nonasbestiform morphologies of the same mineral. This OSHA document was developed to focus primarily on the distinction between asbestiform fiber and cleavage fragments. The document does not specifically address the majority of particle types identified in this study, in particular, prismatic to acicular crystals with morphologies and compositions that meet the counting rules specified in the standard methods. The OSHA document also emphasizes that when the analyst is in doubt the particle should be counted. Furthermore, based on the limited health research available on noncommercial grade material (consistent with what would now be considered "naturally occurring asbestos") it is not clear that when conducting a non-regulatory evaluation of potential exposure that such distinctions should be made as long as the proper caveats are provided. Herein lies the crux of those issues debated in the El Dorado Hills "asbestos" controversy. We believe there are currently no definitive answers to these issues. However, the emerging practice of fully characterizing all particles of potential concern, both chemically and morphologically, will aid in developing appropriate analytical procedures, interpretation of epidemiological data, and development of regulatory policies to deal with situations such as the one in El Dorado Hills.

\section{Issues Raised in the RJLG Review}

The RJLG Review raised three primary mineralogical objections regarding the identification and counting of asbestos and other particles meeting the counting criteria dictated by analytical methods used in The USEPA Study. These objections focused upon (1) the aluminum content of amphiboles and the influence of that chemistry on morphology, (2) the extinction angle (optical) properties of the amphibole particles and the relationship of those properties to morphology, (3) the morphology of the particle population as a whole and whether or not the population represents asbestos or cleavage fragments and (4) TEM selected area electron diffraction (SAED) patterns of El Dorado Hills amphiboles not being typical of asbestos. Each of these issues is discussed below.

\section{Aluminum Content}

In the first argument, The RJLG Review stated that any amphibole containing more than 0.3 cation aluminum per formula unit cannot be asbestos and therefore should not have been counted as asbestos in the USEPA analyses. We disagree with this blanket assertion regarding aluminum content presented by The RJLG Review. Although the vast majority of reported analyses of amphiboles in the asbestiform habit contain aluminum at levels below 0.3 to 0.5 atoms per formula unit (Dorling and Zussman, 1987), there are exceptions. 
Also, there is no research that specifically demonstrates that amphiboles with higher aluminum concentrations cannot form in the fibrous and asbestiform habit (for multiple definitions of asbestiform and related terminology, see Lowers and Meeker, 2002). Therefore, this is not a mineralogical fact as suggested in The RJLG Review but rather a generalized observation to which there are exceptions in the literature.

Research demonstrates that aluminum in primary, unaltered, igneous amphiboles increases as a function of increasing temperature and pressure (Anderson and Smith, 1995, and references therein). This observation, which appears to be linked to the ability of the larger aluminum cation to replace silicon in the tetrahedral site at higher temperatures, may explain the observed low levels of aluminum in asbestiform amphiboles because asbestos tends to form at lower temperatures and pressures (Dorling and Zussman, 1987). However, aluminum levels in amphiboles that form in lower temperature alteration environments will also be highly dependent on rock and fluid chemistry; many, but not all, asbestiform amphiboles form in aluminum-depleted rock types. Another subtle but important consideration is that most published analyses of amphibole asbestos generally refer to material that was classified using a commercial definition of asbestos (for example, fibrous minerals that display properties desirable for commercial use, such as highly flexible, high tensile strength bundles of very thin fibrils) rather than definitions for fibrous amphiboles with morphologies that may grade from nonasbestiform prismatic and acicular habits toward, or into, the asbestiform habit. Therefore, it is difficult to apply any general rules regarding the maximum amount of aluminum that can exist in fibrous amphibole minerals formed by low temperature alteration or that occur as a natural component of soils or dusts generated from soils.

The RJLG Review gave three primary references to support their contention that actinolite asbestos cannot contain high aluminum (more than 0.3 cation per formula unit): Leake and others (1997), Verkouteren and Wylie (2000), and Deer and others (1997). Each of these references requires some discussion to be properly understood in the context used in The RJLG Review.

Leake and others (1997), discussed aluminum content in actinolite only in the context of amphibole nomenclature. Nowhere in the paper did they discuss aluminum content in asbestos. Therefore, this reference does not seem appropriate as cited in the The RJLG Review. As for the aluminum content of actinolite (asbestiform or nonasbestiform), Leake and others (1997) defined a maximum of less than 0.5 aluminum cation in the tetrahedral crystallographic site. However, additional aluminum is also permitted in the octahedral crystallographic site. Thus, the amount of total aluminum in actinolite is not limited to 0.3 cation or even 0.5 cation per formula unit as suggested by The RJLG Review, but rather maximum aluminum content is unspecified. Translating this to a weight percent oxide requires a full quantitative analysis for all of the other elements present; thus, it is not possible to quote a general weight percent limit, such as 1.5 weight percent for $\mathrm{Al}_{2} \mathrm{O}_{3}$.
To reiterate, the "limits" discussed in Leake and others (1997) only relate to nomenclature of the amphibole mineral and are based entirely on chemistry, not on growth habit.

Verkouteren and Wylie (2000) did attempt to correlate the aluminum content in the tremolite-ferro-actinolite series with morphology. To do this they selected 102 "museum quality" samples and defined 34 of these samples as asbestiform, 24 as byssolite, ${ }^{1}$ and 44 as massive. The criteria used for these definitions were somewhat subjective and appear to rely in part on visual observation and in part on the behavior of the sample material when ground in a mortar with a pestle. With these caveats, the results of this study for the actinolite samples tested were as follows: The 11 "asbestiform" actinolite samples contained a maximum of 0.26 aluminum cation per formula unit, the 9 "byssolite" actinolite samples reached a maximum of approximately 0.8 cation per formula unit and the approximately 25 massive actinolite samples reached a maximum of 0.7 cation per formula unit. The tremolite and ferro-actinolite samples did not show similar aluminum discrimination between morphological types. Although this study suggested that asbestiform actinolite may generally have low aluminum content (less than 0.3 cation per formula unit) the study also showed that other fibrous amphiboles, specifically the byssolites, can have considerably more than 0.3 aluminum cation per formula unit. In nature, however, these morphologies are often not distinct; they can grade into each other, and both types can be found to coexist, such as the case in the vermiculite deposit once mined near Libby, Montana (Meeker and others, 2003).

Deer and others (1997) (as in Leake and others, 1997) do not discuss the aluminum content in asbestiform actinolite, but only actinolite in general, and then only briefly with no specific supporting references. The pertinent statement in Deer and others (1997) relating to this issue is "In most tremoliteactinolites the replacement of silicon by aluminum is small (less than 0.3 aluminum per formula unit); the upper limit is arbitrarily defined by nomenclature." This statement is referring to replacement of silicon by aluminum in the tetrahedral site only. The limit of less than 0.3 aluminum cation total suggested by the The RJLG Review was not addressed by Deer and others (1997). In addition, Verkouteren and Wylie (2000) demonstrate that highly fibrous actinolite (samples they described as byssolite) can contain significantly more than 0.3 cation per formula unit total aluminum.

Of the preceding three primary references cited in The RJLG Review to support the limit of 0.3 aluminum per formula unit in asbestos, only Verkouteren and Wylie (2002) specifically address asbestos; that reference demonstrates that fibrous actinolite can contain significantly more than 0.3 aluminum per formula unit. The 11 asbestiform actinolite samples described by Verkouteren and Wylie (2002) had a

\footnotetext{
${ }^{1}$ Byssolite is an imprecise term used to describe a fibrous, often brittle amphibole morphology in which the individual crystals are generally wider than asbestiform fibrils but thinner than acicular crystals. Byssolite crystals can be on the order of 1 to $2 \mu \mathrm{m}$ in width (Veblen and Wylie, 1993) or "often wider than $1 \mu \mathrm{m}$ " (Wylie, 1979).
} 
maximum of 0.3 aluminum per formula unit; however, it is unclear how the morphology was defined by the authors (no particle size data were given), and the distinction between byssolite and asbestos may not be appropriate for noncommercial or nonmuseum grade samples. It should also be noted that these results were by observation and analysis of the selected samples. No fundamental mineralogical property was specifically identified by Verkouteren and Wylie (2000), or in other studies, that would limit higher levels of aluminum (greater than 0.3 cation per formula unit) in asbestiform amphiboles. Figure 23 shows the distribution of the less than $3 \mu \mathrm{m}$ diameter amphibole particles analyzed in this study plotted as a function of aluminum content (both total and tetrahedral aluminum). This plot shows a general trend of decreasing aluminum content with higher aspect ratio. These results are generally compatible with the results reported in Wylie and Verkouteren (2000); however, the amphiboles in this study are not easily categorized.

At least two additional references are pertinent to this discussion that were not cited in The RJLG Review. Gianfagna and Oberti (2001) describe massive to asbestiform fluoro-edenite (an amphibole) with an average of
0.58 aluminum cation per formula unit (2.97 to 5.26 weight percent $\mathrm{Al}_{2} \mathrm{O}_{3}$ ) in the tetrahedral site. Fluoro-edenite is likely to form a solid solution with tremolite due to the arbitrarily defined nomenclature boundaries identified in Leake and others (1997). This amphibole has been associated with increased incidence of mesothelioma in Italy (Gianfagna and others, 2003). A second reference (Thomas, 1982) described a synthetic fibrous to acicular hornblende containing aluminum as high as 2.0 cations per formula unit in the tetrahedral site. Both of these references, along with Verkouteren and Wylie (2000), suggest that fibrous to asbestiform amphibole structures can accommodate appreciable aluminum under certain conditions of formation.

\section{Extinction Angle}

The second mineralogical objection raised in The RJLG Review was that "true asbestos" has an apparent 0 degree extinction angle when viewed in a polarizing microscope. We also do not agree with this assertion in The RJLG Review, particularly when applied to the mineral types identified in The USEPA Study.

\section{SEM-EDS of Amphibole Structures Observed in Soils With $<3 \mu \mathrm{m}$ Width}

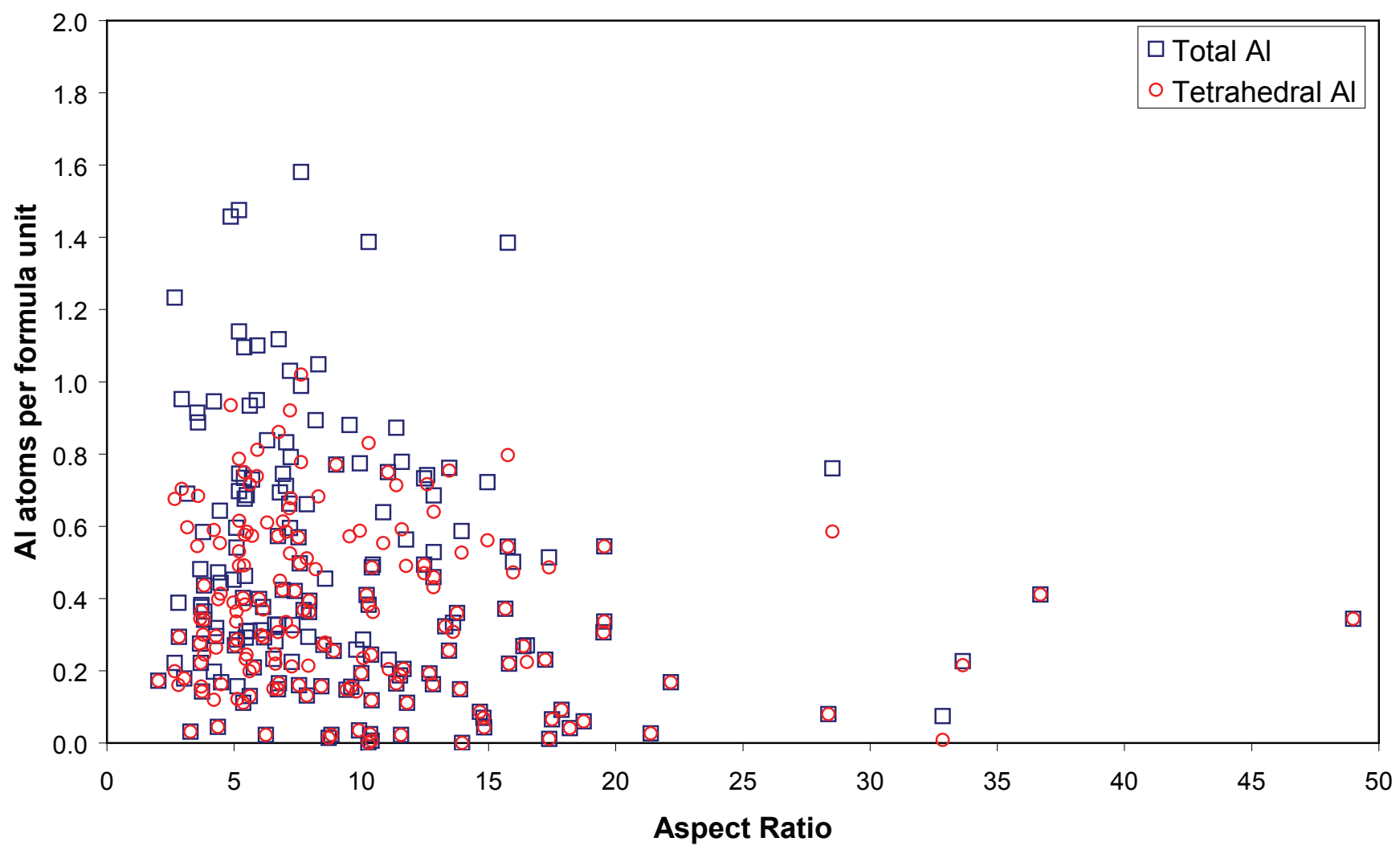

Figure 23. Aluminum (Al) content of amphibole particles less than $(<) 3$ micrometers $(\mu \mathrm{m})$ in width analyzed in this study as a function of aspect ratio. 
This criterion is less studied than the aluminum issue previously addressed herein and is certainly not settled science. A brief explanation is in order to understand the principle behind the assertion. Most amphibole particles (except for orthorhombic types, which generally do not occur in the study area) exhibit oblique extinction (they go dark) at specific maximum angles relative to the $\mathrm{C}$ crystallographic axis (long axis) on a rotating microscope stage, when viewed between crossed polarized filters. This optical property applies to single crystal particles including prismatic, acicular, byssolitic, and single asbestiform fibrils of sufficient diameter to observe optical properties. Cleavage fragments, which are particles that are broken along specific crystallographic planes, also exhibit this property. Asbestiform minerals, as defined for commercial use, are mostly composed of bundles of fibrils; fibrils are the smallest indivisible unit of asbestiform material. The individual fibrils in these bundles can be slightly rotated with respect to each other along the $\mathrm{C}$ crystallographic (long) axis. This rotation causes these bundles to exhibit what amounts to a pseudo zero-degree extinction caused by the averaging of multiple extinction angles of the individual fibrils in the bundle, which is compounded by the limited resolving power of optical microscopes.

Given this rather simplistic explanation, the assertion that all asbestiform (and by inference hazardous) fibrous amphiboles exhibit this property is simply not correct. The primary exception to this general observation is actinolite and chemically related amphiboles. Verkouteren and Wylie (2002) noted that the property of parallel extinction is problematic for actinolite asbestos. They state: "Because of the range in optical properties, especially extinction angle, reliance solely on parallel extinction to distinguish asbestos from non-asbestiform varieties is not recommended." NIOSH (1994) acknowledged that "some" tremolite-actinolite asbestos exhibits parallel extinction, while Occupational Safety and Health Administration (1992) stated that tremolite and actinolite asbestos "usually show" zero degree extinction. It is extremely important to understand that the NIOSH and OSHA references are directed toward analytical methods that were specifically designed to identify commercial-grade asbestos found in the workplace and in commercial products.

In contrast, Brown and Gunter (2003) note that fibrous winchite-richterite amphibole from Libby, Montana exhibits both inclined and parallel extinction, and they remind the reader that the plane on which the fiber lies can also be responsible for parallel extinction regardless of morphology. Unpublished analyses in the USGS Denver Microbeam Laboratory also confirm the observations of Brown and Gunter (2003) and, in addition, we have observed similar behavior (oblique extinction) in a NIOSH tremolite asbestos reference material (NIOSH Standard Reference Material TF-48). These observations demonstrate that, for the tremolite-ferroactionlite series (and also winchite-richterite as observed from Libby amphiboles), the use of parallel extinction to differentiate asbestiform from nonasbestiform material is unreliable. Furthermore, the implication that the property of oblique extinction somehow equates to the absence of toxicity is totally inappropriate, as evidenced by the health problems at Libby, Montana.

Although the zero-degree extinction property may apply to some, and perhaps most, commercial grade asbestos, the optical property is by no means universal, it does not appear to be diagnostic of the tremolite-actinolite-winchite-richterite asbestos group, and it has not been demonstrated to correlate directly with toxicity. It is not at all surprising that noncommercial grade, fibrous and asbestiform amphibole occurring in natural environments could exhibit oblique extinction.

\section{Amphibole Particle Populations Based on Morphology: Cleavage Fragments or Fibers}

The RJLG Review proposed that the particles identified in The USEPA Study contained a population of cleavage fragments rather than a population of asbestiform particles. To address this issue it is possible to compare the often cited data from a U.S. Bureau of Mines (USBM) study (Campbell and others, 1977) with the data from this study. Using SEM analysis at magnifications between 5000 and 10,000 times magnification, Campbell and coworkers demonstrated that a population of tremolite asbestos particles has a significantly different aspect ratio distribution than a population of cleavage fragments (prepared by milling massive tremolite). Figure 24 shows the data from the USBM study compared to aspect ratio data obtained from amphiboles in this study. The results show that the El Dorado Hills amphiboles have an aspect ratio distribution intermediate between that of the tremolite asbestos sample and tremolite cleavage fragments presented by Campbell and others (1977). Several characteristics of the four particle types are illustrated in figure 24: (1) the tremolite asbestos particles from the USBM study have a greater number of higher aspect ratio particles, (2) the peak of the aspect ratio curve for the El Dorado Hills tremolite particles is higher than the USBM tremolite asbestos and the El Dorado Hills actinolite-magnesiohornblende particles, and (3) the USBM cleavage fragment particles have distinctly lower aspect ratios than both El Dorado particle groups. These results are not surprising because cleavage fragments, by definition, are particles produced by breaking, milling, or crushing massive material. As noted above, the El Dorado amphibole particles do not appear to be cleavage fragments but rather prismatic to asbestiform crystals produced by natural weathering of the rocks. Therefore, the assertion by The RJLG Review that the majority of the El Dorado Hill amphiboles are cleavage fragments is not consistent with our data.

The RJLG Review also suggested that TEM SAED patterns obtained by USEPA contract laboratories supported their conclusion that the majority of particles that were counted by USEPA contract laboratories were nonasbestos. Although we did not evaluate TEM data for this report, we believe that such SAED data may often be useful in identifying commercial-grade asbestos but would be ambiguous for particles that 


\section{SEM-EDS Analysis of All Amphibole Particles Observed in Soils}

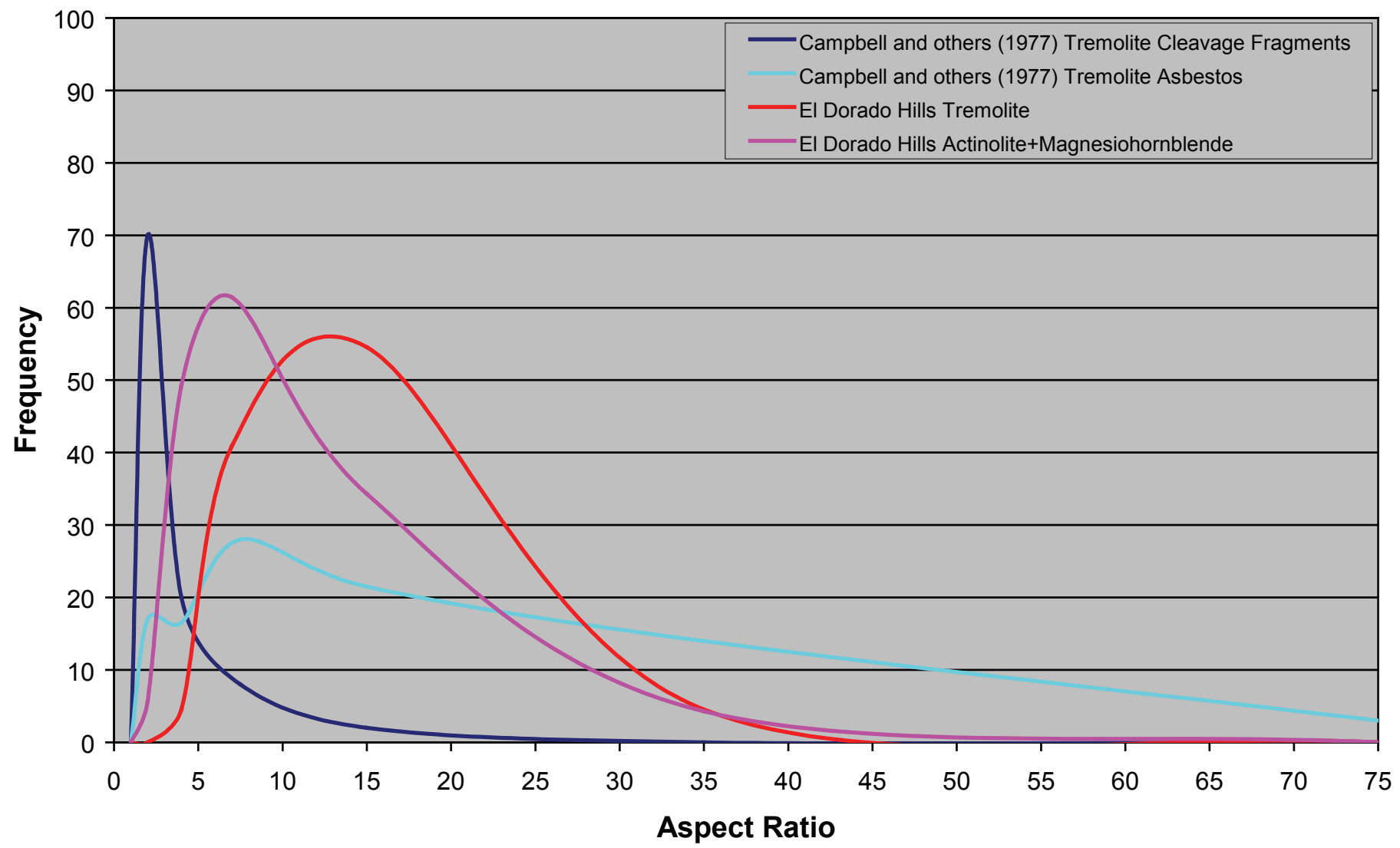

Figure 24. Comparison of amphibole particles from El Dorado Hills, California, to tremolite cleavage fragments and tremolite asbestos analyzed by Campbell and others (1977).

range in morphologies from prismatic to asbestiform such as those found in El Dorado Hills. It is also not clear that lower order zone axis SAED patterns as described in The RJLG Review have been shown in the peer reviewed literature to be requisite for particles that have been directly linked to asbestos-related disease.

\section{Additional Considerations}

With the stated issues in mind, the question still remains as to what materials were collected during activity based sampling conducted by the USEPA and what materials, if any, need be of concern, from a health standpoint, to the residents of the El Dorado Hills area. Clearly, there is fibrous, grading to asbestiform, tremolite-actinolite present in at least some parts of the study area. This material appears to occur in very localized areas associated with the ultramafic rock units at Oak Ridge and exposed locally along Harvard Way, and a smaller ultramafic rock unit exposed at Fairchild Community Park. These localized occurrences should be recognized as possible areas of concern from a health standpoint because the mineralogy and morphology of particles found in these areas is consistent with regulated asbestos.

Other amphiboles identified along New York Creek Trail and other parts of the study area are more difficult to categorize with respect to "naturally occurring asbestos." These amphiboles, although primarily actinolite (about 60 percent of the particles counted), range in composition from actinolite to magnesiohornblende. These particles also tend to be shorter in length and have lower aspect ratios than the tremolitic fibers discussed above. These particles are not asbestiform nor are the majority of them fibrous, although there are a few exceptions as previously noted. We also believe, based on our observations, that the majority of these particles are not cleavage fragments that formed by the breaking of larger massive amphibole crystals. Many of these particles do, however, meet the analytical counting criteria that were designed, not for "naturally occurring" materials of this type, but for identification of commercial-grade asbestos in the workplace and in commercial products. However, if The USEPA Study had been conducted as an enforcement action, it would be difficult to classify the majority of actinolite-magnesiohornblende of the El Dorado Hills area as an 
actionable material because (1) the majority of the particles are prismatic, not fibrous, and (2) approximately 40 percent of the particles are magnesiohornblende. To our knowledge, there are no health-based studies that specifically address the types of actinolite-magnesiohornblende particles identified in this study. Therefore, it is not possible to categorically discount this material as benign from a health standpoint, nor is there direct evidence in the literature that particles of this type pose a health hazard.

Finally, it seems appropriate in light of the issues addressed in this report, to stress that it is absolutely not the role of the analytical or mineralogical communities to make health-based decisions or to make independent analytical assessments that directly or indirectly influence health-based outcomes. It is the obligation of the analytical and mineralogical communities to provide accurate, unbiased, and scientifically sound information to the health and regulatory communities so that appropriate and informed, health-related policy and regulatory decisions can be made.

\section{Summary and Conclusions}

The amphiboles identified in the soil and rock samples collected for this study show a range of compositions from tremolite to magnesiohornblende. Amphiboles with more tremolitic compositions tend to be more fibrous and can grade into asbestiform morphology. The fibrous, tremolitic amphiboles appear to be associated with the ultramafic rock units that occur at Oak Ridge in the southern part of the study area and in limited exposures in Fairchild Park to the north.

The other amphiboles identified in this study are classified as actinolite and magnesiohornblende in composition and generally occur in a more prismatic to acicular morphology. A few fibrous actinolite-magnesiohornblende particles were observed. The actinolite-magnesiohornblende amphiboles are found primairily in the metavolcanic and metasedimentary rock units sampled along the New York Creek Trail, and along Silva Valley Parkway.

The amphibole particles characterized in the samples collected for this study are similar in both chemistry and morphology to the amphiboles we observed on the activity based sampling air filters collected by USEPA. Based on aspect ratio data of the less than $3 \mu \mathrm{m}$ diameter particles, the morphologies of the amphiboles in the El Dorado Hills area are intermediate between what might generally be considered a population of commercial-grade asbestos particles and a population of cleavage fragments, produced by milling of massive amphibole. That is, the El Dorado amphibole particles form an aspect ratio distribution that has higher values and is clearly distinguishable from a cleavage fragment population but does not contain as many high aspect ratio particles as a commercial-grade asbestos population.

A comparison of amphiboles in soils with amphiboles in adjacent rock outcrops suggests that the soil particles are primarily derived from local weathering of rocks and are not the result of deposition from distance sources by wind or water. This suggests that any potential remediation in the area could be accomplished locally, rather than on a broad scale.

We also find that the types of amphiboles that occur naturally in the El Dorado Hills study area are not easily categorized using criteria sometimes employed for identification and characterization of commercial-grade asbestos. Such criteria include aluminum content (or other trace to minor chemistry) and optical properties such as extinction angle. These and other properties of commercial-grade asbestos such as flexibility and tensile strength have not been shown to directly contribute to health effects and should not be the sole basis for exclusion of materials that may otherwise meet demonstrated health-related criteria such as length, width, bulk chemistry, and perhaps surface chemistry. We should also point out that the counting criteria developed for analysis of asbestos in the workplace or in commercial products may not be appropriate for direct application to what is currently referred to as naturally occurring asbestos. We therefore suggest that the health, mineralogical, and regulatory communities consider a thorough evaluation of existing definitions and analytical methods specifically for application to problems such as those in $\mathrm{El}$ Dorado Hills and other areas of the country where similar conditions exist.

\section{Acknowledgments}

The authors would like to thank Mr. Wayne Lowery, General Manager, El Dorado Community Services District for allowing access to the El Dorado Hills Community Center areas and the New York Trail for sampling. We would also like to thank Mr. Rick Fears, P.G., California Department of Toxic Substances Control for helpful discussions regarding local geology and for guiding us to Fairchild Park and other areas for sampling. Dr. Ronald Churchill, John Clinkenbeard, and Christopher Higgins of the California Geological Survey provided invaluable information on local geology, background information on issues relating to naturally occurring asbestos in California, and extremely thorough and beneficial technical reviews of this report. This report also benefited from discussions and technical reviews by Dr. Geoffrey Plumlee and Dr. William Langer, USGS, Denver.

\section{References Cited}

Anderson, J.L., and Smith, D.R., 1995, The effects of temperature and $\mathrm{fO}_{2}$ on the Al-in-hornblende barometer: American Mineralogist, v. 80, p. 549-559.

Brown, B.M., and Gunter, M.E., 2003, Morphological and optical characterization of amphiboles from Libby, Montana U.S.A. by spindle stage assisted polarized light microscopy: Microscope, v. 51, p.121-140. 
Burt, R., ed., 2004, Soil survey laboratory methods manual: Soil Survey Investigations Report, No. 42, version 4.0, United States Department of Agriculture, Natural Resources Conservation Service, 735 p.

Cady, W.M., Albee, A.L., and Chidester, A.H., 1963, Bedrock geology and asbestos deposits of the upper Missisquoi Valley and vicinity, Vermont: U.S. Geological Survey Bulletin 1122-B, 78 p., 1 plate.

Campbell, W.J., Blake, R.L, Brown, L.L., Cather, E.E., and Sjober, J.J., 1977, Selected silicate minerals and their asbestiform varieties: U.S. Bureau of Mines Information Circular $8751,56 \mathrm{p}$.

Chidester, A.H., Albee, A.L., and Cady, W.M., 1978, Petrology, structure, and genesis of the asbestos-bearing ultramafic rocks of the Belvidere Mountain area in Vermont: U.S. Geological Survey Professional Paper 1016, 95 p., 4 plates.

Churchill, R.K., Higgins, C.T., and Hill, Bob, 2000, Areas more likely to contain natural occurrences of asbestos in western El Dorado County, California: Sacramento, California Department of Conservation, Division of Mines and Geology Open-File Report 2000-002, 66 p., 1 plate, scale 1:100,000.

Clark, L.D., 1964, Stratigraphy and structure of part of the Western Sierra Nevada Metamorphic Belt, California: U.S. Geological Survey Professional Paper 410, 70 p., 11 plates.

Clark, L.D., 1976, Stratigraphy of the north half of the Western Sierra Nevada Metamorphic Belt, California: U.S. Geological Survey Professional Paper 923, 26 p., 1 plate, scale $1: 316,800$.

Clark, R.N., King, T.V.V., Klejwa, M., Swayze, G.A., and Vergo, N., 1990, High spectral resolution reflectance spectroscopy of minerals: Journal of Geophysical Research, v. 95, p. 12653-12680.

Clark, R.N., Swayze, G.A., Livo, K.E., Hoefen, T.M., Kokaly, R., and Wise, R., 2003, The U.S. Geological Survey, Digital Spectral Library splib05a: U.S. Geological Survey OpenFile Report 2003-395.

Clinkenbeard, J.P., Churchill, R.K., and Lee, Kiyoung, eds., 2002, Guidelines for geologic investigations of naturally occurring asbestos in California: Sacramento, California Department of Conservation, California Geological Survey Special Publication 124, 70 p.

Deer, W.A., Howie, R.A., and Zussman, J., 1997, Rock-forming minerals - Double chain silicates: The Geological Society, v. 2B 2d ed., London.

Dorling, M., and Zussman, J., 1987, Characteristics of asbestiform and non-asbestiform calcic amphiboles: Lithos, v. 20, p. 469-489.
Ecology and Environment, Inc. 2005, El Dorado Hills naturally occurring asbestos multimedia exposure assessment, El Dorado Hills, California: Preliminary assessment and site inspection report, Interim final, Contract No. 68-W-01-012; TDD No. 09-04-01-0011; Job No. 001275.0440.01CP.

Evans, B.W., 2004, The serpentinite multisystem revisitedChrysotile is metastable: International Geology Review, v. 46 , p. 479-506.

Faust, G.T., and Fahey, J.J., 1962, The serpentine-group minerals: U.S. Geological Survey Professional Paper 384-A, 92 p.

Gianfagna, A., Ballirano, P., Bellatreccia, F., Bruni, B., Paoletti, L., and Oberti, R., 2003, Characterization of amphibole fibres linked to mesothelioma in the area of Biancavilla, Eastern Sicily, Italy: Mineralogical Magazine, v. 67, p. 1221-1229.

Gianfagna, A., and Oberti, R., 2001, Fluoro-edenite from Biancavilla: crystal chemistry of a new amphibole endmember: American Mineralogist, v. 86, p. 1489-1493.

Hunt, G.R., 1977, Spectral signatures of particulate minerals in the visible and near infrared: Geophysics, v. 42 no. 3 , p. 501-513.

Leake, B.E., Woolley, A.R., Arps, C.E.S., Birch, W.D., Gilbert, M.C., Grice, J.D., Hawthorne, F.C., Kato, Akira, Kisch, H.J., Krivovichev, V.G., Linthout, Kees, Laird, Jo, Mandarino, J.A., Maresch, W.V., Nickel, E.H., Rock, N.M.S., Schumacher, J.C., Smith, D.C., Stephenson, N.C.N., Ungaretti, Luciano, Whittaker, E.J.W., and Youzhi, Guo, 1997, Nomenclature of amphiboles-Report of the Subcommittee on Amphiboles of the International Mineralogical Association, Commission on New Minerals and Mineral Names: American Mineralogist, v. 82, p. 1019-1037.

Lowers, H.A., and Meeker, G.P., 2002, Tabulation of asbestos-related terminology. U.S. Geological Survey Open-File Report 02-458; available on the World Wide Web at http:// pubs.usgs.gov/of/2002/ofr-02-458/index.html

Meeker, G.P., Bern, A.M., Brownfield, I.K., Lowers, H.A., Sutley, S.J., Hoefen, T.M., and Vance, J.S., 2003, The composition and morphology of amphiboles from the Rainy Creek Complex, near Libby, Montana: American Mineralogist, v. 88, p. 1955-1969.

National Institute for Occupational Health and Sciences, 2002, Statement by Dr. Gregory Wagner, M.D., Director, Division of Respiratory Disease Studies, National Institute for Occupational Health and Sciences, before the Senate Subcommittee on Superfund, Toxics, Risk, and Waste Management, June 20, 2002; available on the Worldwide Web at http:// eps.senate.gov/107th/Wagner_062002.htm

National Institute of Occupational Science and Health, 1994, Asbestos (bulk) by PLM, Method 9002: Manual of Analytical Methods, $4^{\text {th }}$ ed. 
Occupational Safety and Health Administration, 1992, Polarized light microscopy of asbestos: Method ID 191.

R.J. Lee Group, Inc., 2005, Evaluation of EPA's analytical data from the El Dorado Hills asbestos evaluation project: R.J. Lee Group, Inc.

Schweickert, R.A., Hanson, R.E., and Girty, G.H., 1999, Accretionary tectonics of the Western Sierra Nevada Metamorphic Belt, in Wagner, D.L., and Graham, S.A., eds., Geologic field trips in northern California-Centennial Meeting of the Cordilleran Section of the Geological Society of America: California Geological Survey Special Publication 119, p. 33-79.

Springer, R.K., 1971, Geology of the Pine Hill intrusive complex, El Dorado County, California: Davis, University of California Ph.D. dissertation, 362 p., 3 plates.

Swayze, G.A., Higgins, C.T., Clinkenbeard, J.P., Kokaly, R.F., Clark, R.N., Meeker, G.P., and Sutley, S., 2004, Preliminary report on using imaging spectroscopy to map ultramafic rocks, serpentinites, and tremolite-actinolite-bearing rocks in California: U.S. Geological Survey Open-File Report 2004-1304, 20 p.

Swayze, G.A., Clark, R.N., Sutley, S.J., Hoefen, T.M., Plumlee, G.S., Meeker, G.P., Brownfield, I.K., Livo, K.E., and Morath, L.C., 2006, Chapter 3, Spectroscopic and X-ray diffraction analyses of asbestos in the World Trade Center dust, in Urban Aerosols and Their Impacts: Lessons
Learned from the World Trade Center Tragedy, Gaffney, J.S., and Marley, N.A., eds: American Chemical Society Symposium Series, 919, p. 40.

Thomas, W.M., 1982, Stability relations of the amphibole hastingsite: American Journal of Science, v. 282, p. 136-164.

Veblen, D.R., and Wylie, A.G., 1993, Mineralogy of amphiboles and 1:1 layer silicates, in G.D. Gutheri, Jr. and B.T. Mossman, eds., Health effects of mineral dusts, Reviews in Mineralogy, v. 28: Mineralogical Society of America, Washington, D.C., p. 61-137.

Verkouteren, J.R., and Wylie, A.G., 2000, The tremoliteactinolite-ferro-actinolite series, Systematic relationships among cell parameters, composition, optical properties, and habit, and evidence of discontinuities: American Mineralogist, v. 85, p. 1239-1254.

Verkouteren, J.R., and Wylie, A.G., 2002, Anomalous optical properties of fibrous tremolite, actinolite, and ferroactinolite: American Mineralogist, v. 87, p. 1090-1095.

Wagner, D.L., Jennings, C.W., Bedrossian, T.L., and Bortugno, E.J., 1987, Geologic map of the Sacramento quadrangle, California: California Geological Survey Regional Geologic Map Series Map No. 1A, 4 sheets, scale 1:250,000.

Wylie, A.G., 1979. Optical properties of fibrous amphiboles: Annals of the New York Academy of Sciences, v. 330, p. 611-619. 


\section{Appendix A}

Appendix A contains an aerial photo map of the El Dorado Hills study area showing USGS sampling locations (Figure A1) and a spreadsheet with sampling site descriptions (Table A1).

\section{Appendix B}

Appendix B contains optical photomicrographs of polished thin sections and electron photomicrographs showing the locations of EPMA analysis points.

\section{Appendix C}

Appendix C contains electron photomicrographs of particles from USGS soil and stub samples analyzed on the SEM. These images are stored in folders by sample number. Also included are the SEM photomicrographs of particles from selected USEPA air filter samples. Table C1 shows the original USEPA air filter sample numbers.

Table C1. Key to USEPA filter numbers described in this report.

\begin{tabular}{|c|c|}
\hline EPA Sample No./Description & USGS assigned filter number \\
\hline 041174-04/SRA R02-100104 & EPA filter \#1 \\
\hline 041210-12/SRA R01-100604 & EPA filter \#2 \\
\hline 041188-59/BLKL21CH 100504 & EPA filter \#3 \\
\hline 041188-63/BLKL24CH 100504 & EPA filter \#4 \\
\hline 041191-20/ JOGB L2 2AD 100704 & EPA filter \#5 \\
\hline 041191-21/ JOGB L2BAD 100704 & EPA filter \#6 \\
\hline 041172-57/CC2-H8-4CT 100304 & EPA filter \#9 \\
\hline 041191-95/TRA H8 ITR 100904 & EPA filter \#10 \\
\hline
\end{tabular}

\section{Appendix D}

Appendix D contains a spreadsheet that includes tables of EPMA data, SEM data, and size data for particles analyzed in sample ED06-07A. 


\section{Glossary of Terms as Used in this Report (not defined in text).}

A

Acicular A mineral morphology where individual grains (crystals) are very long and thin.

Albite A plagioclase feldspar of the nominal composition $\mathrm{NaAlSi}_{3} \mathrm{O}_{8}$. Forms a solid solution with anorthite.

Amphibole A group of double chain silicate minerals with the general formula

$\mathrm{A}_{0-1} \mathrm{~B}_{2} \mathrm{C}_{5} \mathrm{~T}_{8}(\mathrm{OH}, \mathrm{F}, \mathrm{Cl})_{2}$ with common components $\mathrm{A}=\mathrm{Na}, \mathrm{K} ; \mathrm{B}=\mathrm{Ca}, \mathrm{Na}, \mathrm{Li}, \mathrm{Mg}, \mathrm{Fe} ; \mathrm{C}=$ $\mathrm{Mg}, \mathrm{Fe}, \mathrm{Al}, \mathrm{Ti}, \mathrm{Mn} ; \mathrm{T}=\mathrm{Si}, \mathrm{Al}$.

Andesite (andesitic) A fine-grained volcanic rock composed primarily of sodic feldspar, various mafic minerals, and minor quartz.

Ankerite A carbonate mineral with nominal composition $\mathrm{Ca}\left(\mathrm{Fe}^{2+}, \mathrm{Mg}, \mathrm{Mn}\right)\left(\mathrm{CO}_{3}\right)_{2}$.

Anorthite A plagioclase feldspar of the nominal composition $\mathrm{CaAl}_{2} \mathrm{Si}_{2} \mathrm{O}_{8}$. Forms a solid solution with albite.

Antigorite A serpentine group mineral of the composition $\left(\mathrm{Mg}, \mathrm{Fe}^{2+}\right)_{3} \mathrm{Si}_{2} \mathrm{O}_{5}(\mathrm{OH})_{4}$.

Apatite A mineral group with the general formula $\mathrm{A}_{5}(\mathrm{XO} 4)_{3}(\mathrm{~F}, \mathrm{Cl}, \mathrm{OH}, \mathrm{CH})$ with common components $\mathrm{A}=\mathrm{Ca}, \mathrm{K}, \mathrm{Na}, \mathrm{Ba} ; \mathrm{X}=\mathrm{P}$, $\mathrm{Si}, \mathrm{V}, \mathrm{As}$.

Asbestiform Fibrous minerals possessing the properties of commercial-grade asbestos such as flexability, high tensile strength, long thin fibers occurring in bundles.

Augite A single chain silicate with nominal composition $(\mathrm{Ca}, \mathrm{Na})(\mathrm{Mg}, \mathrm{Fe}, \mathrm{Al}, \mathrm{Ti})(\mathrm{Si}, \mathrm{Al})_{2} \mathrm{O}_{6}$.

\section{C}

Clinochlore A chlorite group mineral with the nominal composition $(\mathrm{Mg}, \mathrm{Al})_{6}(\mathrm{Si}, \mathrm{Al})_{4} \mathrm{O}_{10}$ $(\mathrm{OH})_{8}$.

Chlorite A sheet silicate mineral group with the general formula $\mathrm{A}_{4-6} \mathrm{Z}_{4} \mathrm{O}_{10}(\mathrm{OH}, \mathrm{O})_{8}$ with common components $\mathrm{A}=\mathrm{Al}, \mathrm{Fe}, \mathrm{Mg}, \mathrm{Mn}$, $\mathrm{Ni} ; \mathrm{Z}=\mathrm{Al}, \mathrm{Fe}, \mathrm{Si}$.

Chromite An oxide mineral of the nominal composition $\mathrm{Fe}^{2+} \mathrm{Cr}_{2} \mathrm{O}_{4}$.

E

Epidote A silicate mineral group with the general formula $\mathrm{A}_{2} \mathrm{~B}_{3}\left(\mathrm{SiO}_{4}\right)_{3}(\mathrm{OH})$ with common components $\mathrm{A}=\mathrm{Ca} ; \mathrm{B}=\mathrm{Al}, \mathrm{Fe}, \mathrm{Mg}, \mathrm{Mn}$.

$\mathbf{F}$

Ferro-actinolite A calcic amphibole of the nominal composition $\mathrm{Ca}_{2} \mathrm{Fe}^{2+}{ }_{5} \mathrm{Si}_{8} \mathrm{O}_{22}(\mathrm{OH})_{2}$.

Fibrous Having morphological properties similar to organic fibers.

\section{L}

Lizardite A serpentine group mineral of the composition $\left(\mathrm{Mg}, \mathrm{Fe}^{2+}\right)_{3} \mathrm{Si}_{2} \mathrm{O}_{5}(\mathrm{OH})_{4}$.

\section{M}

Muscovite A sheet silicate mineral with the nominal composition $\mathrm{KAl}_{2}\left(\mathrm{AlSi}_{3}\right) \mathrm{O}_{10}(\mathrm{OH})_{2}$.

N

Naturally occurring asbestos Asbestos occurring in its original geologic setting or asbestos transported from its original geological setting by natural processes.

0

Orthoclase A feldspar mineral of nominal composition $\mathrm{KAlSi}_{3} \mathrm{O}_{8}$.

P

PCME (phase contrast microscopy equivalent). Asbestiform structures identified through TEM analysis that are equivalent to those that would be identified in the same sample through phase contrast microscopy analysis. 
Prismatic Having the shape of a prism.

Pumpellyite A silicate mineral with the nominal composition $\mathrm{Ca}_{2}(\mathrm{Mg}, \mathrm{Al}) \mathrm{Al}_{2} \mathrm{Si}_{3}$ $(\mathrm{O}, \mathrm{OH})_{14}$.

\section{0}

Quartz A form of $\mathrm{SiO}_{2}$.

\section{T}

Talc A sheet silicate mineral with the nominal composition $\mathrm{Mg}_{3} \mathrm{Si}_{4} \mathrm{O}_{10}(\mathrm{OH})_{2}$.

Titanite A silicate mineral of the nominal composition $\mathrm{CaTiSiO}_{5}$.

Tridymite A form of $\mathrm{SiO}_{2}$.

V

Vermiculite A sheet silicate mineral of the nominal composition $\left(\mathrm{Mg}, \mathrm{Fe}^{2+}, \mathrm{Al}\right)_{3}(\mathrm{Si}, \mathrm{Al})_{4}$ $\mathrm{O}_{10}(\mathrm{OH})_{2} \bullet 4 \mathrm{H}_{2} \mathrm{O}$. 